Portland State University

PDXScholar

\title{
An Analysis of Women's Jobs in the Middle East, 610 A.D.-1982
}

Malakeh Taleghani

Portland State University

Follow this and additional works at: https://pdxscholar.library.pdx.edu/open_access_etds

Part of the Business Commons, Feminist, Gender, and Sexuality Studies Commons, and the Near and Middle Eastern Studies Commons

Let us know how access to this document benefits you.

\section{Recommended Citation}

Taleghani, Malakeh, "An Analysis of Women's Jobs in the Middle East, 610 A.D.-1982" (1983).

Dissertations and Theses. Paper 3454.

https://doi.org/10.15760/etd.5338

This Thesis is brought to you for free and open access. It has been accepted for inclusion in Dissertations and Theses by an authorized administrator of PDXScholar. Please contact us if we can make this document more accessible: pdxscholar@pdx.edu. 
AN ANALYSIS OF WOMEN'S JOBS IN THE MIDDLE EAST

610 A.D. - 1982

by

MALAKEH TALEGHANI

A professional paper submitted in partial fulfillment of the requirements for the degree of

\section{MASTER OF SCIENCE IN TEACHING \\ in \\ BUSINESS EDUCATION}

Portland State University

1983 
TABLE OF CONTENTS

PAGE

ACKNOWLE DGMENTS . . . . . . . . . . . . . . . . .

LIST OF TABLES . . . . . . . . . . . . . . . . . v

CHAPTER

I INTRODUCTION . . . . . . . . . . . . . 1

Statement of the Problem ..... . . . . . 2

Purpose of the Study ................ . . . . 3

Delimitations and Limitations of the Study . . . 3

Definition of Terms............. 4

Summary ................. 6

II FACTORS THAT HAVE INFLUENCED WOMEN'S ROLES

(JOB, CAREER, AND BUSINESS) . . . . . . . . . 7

Religion and Tradition ........... 7

Islam . . . . . . . . . . . 8

Koran .................... 99

Koranic Rules About Women ......... 10

Summary . . . . . . . . . . . . 16

III WOMEN'S ROLES FROM THE SEVENTH TO THE TWENTIETH

CENTURY HISTORICALLY . . . . . . . . . . . 18

Introduction . . . . . . . . . . . 18

Women's Education Before Changes . . . . . . 18

Poets, Scholarly and Learned Women . . . . 22

Women's Jobs and Skills Before Changes . . . . 24

Women in High Positions . . . . . . . 25

Summary . . . . . . . . . . . . . . 29

IV WOMEN'S ROLES AFTER CHANGES FROM THE BEGINNING

OF THE TWENTIETH CENTURY UP TO 1982 . . . . . . . . 31

Introduction . . . . . . . . . . . 31

Factors of Changes Regarding Women's Status... 32

Women's Education and the Percentage of

Their Educational Enrollment . . . . . . . 32

Primary Education ............. 33

Secondary Education . . . . . . . . . 33 
Vocational Education . . . . . . . . 34

Higher Education . . . . . . . . . . . . . . . . . 37

Field of Study ............... 37

Women's Education in Iran ........... 38

Women's Education in Egypt . . . . . . . . . . 44

Summary .. . . . . . . . . . . . . 49

V. WOMEN'S EMPLOYMENT AND WORKFORCE . . . . . . . . . 51

Introduction . . . . . . . . . . . . 51

Percentage of Women's Workforce and the

Relation Between the Economy and Women's

Workforce Rate . . . . . . . . . . . . . 51

The Effect of Religion and Tradition on

the Youth Attitude Towards Women's Roles . . . . 57

Women's Jobs in Iran . . . . . . . . . . . 67

Women's Jobs in Egypt .............. 75

Summary ................... 84

Obstacles to Change .............. 86

VI. CONCLUSION AND PROPOSAL . . . . . . . . . . . . 87

FOOTNOTES . . . . . . . . . . . . . . . . . . 89

BIBLIOGRAPHY • . • . . . . . . . . . . . . . . . 93

APPENDIX . . . . . . . . . . . . . . . . . . . . 97 


\section{ACKNOWLEDGEMENTS}

Our Prophet and our culture have taught me to have great respect and appreciation for any person who has taught me even a word. As the Prophet says: "Who taught you one word made you a devoted follower of himself."

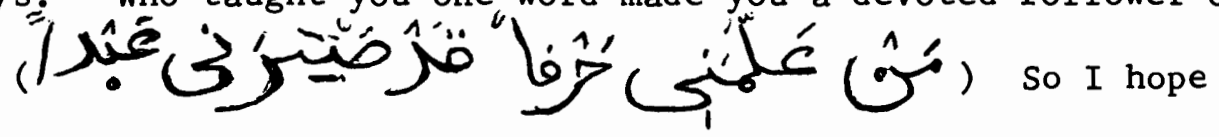
that my deep gratitude and thanks will be accepted by Dr. Leonard F. Robertson. He guided me, helped me, and taught me a lot of things during my graduate program, including giving his time and assistance in the preparation of this professional paper. Consequently, I am indebted to him.

Also my thanks and appreciation are due to all of my professors who helped me throughout my graduate program, particularly Dr. Carl H. Pollock and Dr. George Guy for their extra time and attention that they spent helping me in the completion of my professional paper. I am also grateful to Mrs. Bonnie Drinkard for editing and typing this paper and for her helpful guidance. 


\section{LIST OF TABLES}

TABLE

PAGE

I Percentage of Females of All Students

by Level of Education in the Arab World . . . . . . 35

II Statistical Survey of Iranian Education for

the Years 1947-48 and 1955-56 ... . . . . . . 42

III Statistical Survey of Iranian Education . . . . . . . . 43

IV A Summary of School Statistics in Iran . . . . . . . . . 45

V Summary of School Statistics 1950-54 in Egypt . . . . . . 47

VI Comparative Differences Between Female

Participation . . . . . . . . . . . 53

VII Occupational Distribution and Industrial Composition

of the Total Non-agricultural Labor Force . . . . . 55

VIII Youth Attitudes on Women's Role by Sex . . . . . . . . . 60

IX Boys' Attitudes on Women's Role by Religion . . . . . . . 62

X Girls' Attitudes on Women's Role by Religion . . . . . . 63

XI Total and Economically Active Population by Sex

and Age Group in Iran . . . . . . . . . . . 71

XII Structure of the Economically Active Population in Iran . .72

XIII Total and Economically Active Population by Sex

and Age Group in Egypt . . . . . . . . . . . 79

XIV General Level of Employment in Egypt . . . . . . . . 81

XV Employment in Non-agricultural Sectors in Egypt . . . . . 82

XVI Employment in Manufacturing in Egypt . . . . . . . . 83 


\section{CHAPTER I}

\section{INTRODUCTION}

History is the documentation of human endeavors and changes. The status of women in the family and in society is changing historically, but there is not enough study and survey about the position of women in most of the countries to find out the factors which influenced the situation of women and the factors that have made them subordinate.

In this survey, women's roles (jobs) and their participation in the workforce in the Muslim Middle-Eastern countries will be discussed generally; moreover, some of the Middle-Eastern countries, such as Egypt and Iran, will be studied a little more specifically as a sample. The status of women, their education, skills, and profession, will be explained historically from the date of the Islamic period until today. The problems and factors that prohibited women from having outside jobs, social life, and equal rights in past and present times (from 610 A.D. to 1982) will be analyzed. On the other hand, the attempt is to make a general picture of women's conditions in the society to which they belong from the time of Muslim's Prophet until today.

Since most of the Middle-Eastern countries are Muslim, Islam and its holy book, the Koran, are essentially rules and the most important law for them; also the structure of Muslim is almost the same for all Muslim countries, so women's roles will be studied from the point of Islamic view and its holy book, the Koran, first, then other factors. 
The investigation will be in six chapters. In the first three chapters discussion will be about women's status historically from 610 A.D. up to the beginning of the twentieth century (the beginning of the changes). The second three chapters will deal with changes in women's conditions, education, and place in the workforce. For a better understanding, there will be a comparison between some MiddleEastern countries and Latin America, which are economically similar but have a different dominant religion, and are in a different location.

This investigation has been derived from related literature in English, Persian, and Arabic languages; moreover, some interviews with a few native Middle-Eastern students and families have been done at Portland State University and Portland Community College. These will be discussed in the second three chapters.

\section{Statement of the Problem}

The goal of this investigation is to determine the conditions of employment for women and their education and skills in the MiddleEastern countries and to analyze the factors which have traditionally and lawfully kept the female participation in the workforce at a low rate. In analyzing those factors, the following questions should be answered :

1. What countries are in the Middle East?

2. What factors have influenced women's status and their outside jobs and business?

3. What percentage of women are educated and skilled? 
4. What percentage of the employed workforce are women?

5. Does the economy have an essential effect on the female workforce rate?

6. Does religion have the same effect on the attitudes of youth toward women's roles today as it had previously?

\section{Purpose of the study}

This study is being done for four reasons:

The first reason is to determine women's status regarding education, jobs, and business, in general in the Middle East.

The second reason is to analyze the factors which have historically prohibited women from being educated and having contributed to the workforce from the past to the present time.

The third reason is to find out the effect of changes in the Middle East on women's status and their position in point of view of education, skill, and employment.

The fourth reason is to describe the attempt that should be made to develop women's position and their participation in public activities in Middle-Eastern countries.

\section{Delimitations and Limitations of the Study}

This investigation deals with actual research studies and selected writings from the Islamic period (610 A.D.) pertaining to women's education, skills, and careers in the Muslim Middle-Eastern countries and comparing them with skills of women in other countries that have a similar economy. The study includes available research studies, literature, and articles in the United States and Iran. 
The limitations of the study are as follows:

1. This survey is valid and reliable only to the extent of the validity and reliability of the primary data used.

2. In addition to research studies and reports, some personal interviews have been done at Portland State University and Portland Community College for more comprehensive data.

3. The data collected from research studies and selected related literature are limited by their timeliness.

\section{Definition of Terms}

The following terms are used as defined:

Middle-Eastern Countries (M.E.). In order to better understand women's roles (jobs) in the M.E., it is first necessary to know which countries constitute the M.E. and where they are located. The Middle East that in this research will be abbreviated as M.E. is comprised of countries located in Southwestern Asia and Northern Africa. Although there are several definitions of the term "M.E." and which countries it encompasses, for the purpose of this research, the North African countries of Morocco, Algeria, Libya, Egypt, Tunisia, and Sudan, also the Southwest Asian countries of Syria, Lebanon, Iran, Saudi Arabia, Qatar, Kuwait, North and South Yemen, Oman, Bahrain, Iraq, Jordan, Afghanistan, and Pakistan will be included.

Turkey, which is located to the northwest of Iran, is considered part of the M.E. in some definitions and will be included in this research. Most Turkish people take exception to such inclusion and regard Turkey as a European country because it is connected to the European continent, but the majority of Turkey's population are Moslem, 
as in other M.E. countries. Many conservative ideas associated with Islam were spread throughout the Muslim world in the sixteenth and seventeenth centuries by Turkish leaders during Turkey's ottoman Empire, when Turkey was one of the most powerful countries in the world. Today Turkey is one of the most liberated Muslim countries with regard to women, and it therefore seems appropriate to include Turkey in any definition of the term "M.E." A map of the M.E. countries is in the Appendix, p. 100.

Most of the M.E. countries are Arab and Arabic is spoken, except Turkey, Iran, Afghanistan, and Pakistan. Turkey's official language is Turkish ( $90 \%$ Turks, $7 \%$ Kurds, $1.2 \%$ Arabs) ${ }^{1}$ Iran's is Persian or Parsi ( $66 \%$ Iranians, $25 \%$ Turks, 5\% Kurds, $4 \%$ Arabs) ; ${ }^{2}$ Afghanistan's is Pushtu (Dari Persian); ${ }^{3}$ and Pakistan's is Urdo and English, both being official. 4

Islam and Muslim. The term "Islam" means submission to God. The formal and popular religion in most of the M.E. countries is Islam. The majority of the people in these countries are Islamite and referred to as Muslim (the people who believe Islam). Islam has two large and important branches, which are: a) Sunnite, b) Shiah. But the basic beliefs about women and their social status in these two branches are almost the same, as described in the Koran. According to different sources, the number of Muslims in the world is different; for example, World Almanac says that there are over one-half billion Muslims in the world, ${ }^{5}$ but according to the Islamic Center there are one billion Muslims worldwide. ${ }^{6}$ The majority are of sunnite sect and the minority are Shiah. The majority of the Shiah are Iranian and live in Iran and Iraq. 
A.H. (after Hegira--departure or emigration). The Islamic calendar begins from the date that Mohammed (Muslim Prophet) made his exodus from Mecca to Medina in 622 A.D., which is called the Hegira. For example, 622 A.D. is the first year of the Muslim calendar and it will be presented as $622 / 1$ or $\frac{622}{1}$ or $\frac{1982}{1361}$.

Koran. The Muslim holy book which was revealed to Mohammed from God.

Joze and Sura. The Koran has 30 parts or jozes and 114 suras or chapters.

Hadith. Hadith or discourse is the Prophet's sayings which are collected by his followers and are the most important rules after the Koran and its 114 suras.

Caliph. The name of Islamic rulers who ruled the Islamic world from the seventh to the seventeenth century.

Imam. The Prophet's successors from Ali's line are called imam among the Shiah sect.

ISIC. International Standard Industrial Classification.

ISCO. International Standard Classification of occupations.

\section{$\underline{\text { Summary }}$}

An attempt was made to give general guidelines on women's status and jobs in the M.E. The reason for this investigation is to provide more insight into the situation of women from the point of view of employment and social status in the M.E. generally.

The reliability of the sources has been interpreted in historical perspective and analysis of the factors. 


\section{FACTORS THAT HAVE INFLUENCED WOMEN'S ROLES (JOB, CAREER, AND BUSINESS)}

This chapter is derived from the related historical literatures which have been studied. There are several factors which have ascertained women's status in the M.E. countries, such as: religion, laws, traditions and customs, Western influences and political matters, governmental interests, and understanding. The most important of these factors are religion and traditions which almost surpassed other factors and had very deep and strong roots in all Muslim societies for more than fourteen centuries and still have and are the strongest factors among the mass of all countries even today. The laws in all of these countries have been touched by religion. In other words, the basic 1 aw is the Koran, Islam's holy book.

\section{$\underline{\text { Religion and Tradition }}$}

As stated before, the predominant religion in the M.E. countries is Islam and the majority of the people are Muslim. The governments, therefore, reflect Islamic law. Many government rules are based on the Koran, following its religious rules. There are over one billion Muslims in the world and half of them are women. These Muslim women are living in different countries that have different cultures, customs, and traditions. Indeed, not only religion but the traditions and 
customs of these countries affect women's roles, so there are variations in women's situations and status in these countries. In fact, the roles of women in these countries differ because, on the one hand, of various interpretations of the Koranic law which exists, and on the other hand, because of different traditions and customs. In some of these countries, traditional beliefs are so strong that they overshadow Koranic rules and dominate the religion. In some countries, tradition has become the strongest part of their religion. Because of this powerful relationship between religion and governmental policy in M.E. countries, it is difficult to truly understand the nature of women's roles in these societies without first having some general understanding of Islam and its rules regarding women and family matters.

Islam. Since religion is the base of governmental policy and rules in the M.E. countries, it could be the basic factor for women's roles, so to understand where women were in the past and where they are now, it is important to take a look at religion and its attitude toward women.

The researcher will take you on a quick trip back into time to the beginning of Islam (610 A.D.), the religion of the M.E. countries, to get brief information about the rules and attitudes of Islam toward women.

Islam is considered the most modern major religion because it is only 1,400 lunar years old, in contrast to Christianity, which is about 2,000 years old, and Buddhism, which has existed for nearly 2,600 years. 7

The sacred text of Islam is the holy Koran and Mohamed is the Prophet. He is believed by Muslims to be the final messenger from God. 
Mohammed was born in Mecca ${ }^{8}$ in 570 A.D. This was a tribal place. It had a small caravan route, and had long been the center of pagan cult worship, and a place of pilgramage. There existed many forms of social injustice based on $\mathrm{clan}$ and kin affiliation. Women had absolutely no rights. The birth of a baby girl was a great shame for the father, and daughters were frequently buried at birth. A father would grieve more for the illness or death of his camel than for the loss of a girl child. Although there existed a majority of poor and helpless people, merchants pursued individual interests and ignored their duty to the needy. ${ }^{9}$ It was the situation of the majority of people of that time.

Mohammed was a young man with a great deal of integrity and compassion. He spent a lot of time thinking about the injustices, especially towards the poor. He had married an older wealthy widow. Finally, during the month of Ramadan, ${ }^{10}$ in the year 610 A.D., while he sat in a cave contemplating these injustices, a voice came to him, saying, "You are the messenger of God." It was at this time that Mohammed began his quest for unification of the Arab nation and for a just and equitable social system, especially regarding the poor. Koran. For the next 23 years, Mohammed continued to receive revelations through the Angel Gabriel from God. These were at frequent intervals. Sometimes they were memorized by Mohammed and his followers, and sometimes they were written down. Around 650 A.D. they were collected and written down in their entirety,composing Mohammed's sacred text, the Koran. ${ }^{11}$ This holy text later became the basic law and rules for Muslim 
countries. Mohammed did Hegira (departure from Mecca to Medina in 622 A.D.). Later this date became the start of the Muslim calendar-622 A.D. $/ 1$ H.

All Muslims believe that the Koran is God's word which was revealed to Mohammed in Mecca and Medina. This holy Book has 114 suras and 30 jozes (parts), which constitute every Muslim main reference for not only spiritual matters but also for matters of day-to-day living. Also, the Koran is the most important and holy basis of law for every ruler of Muslim societies and for all branches of Islam. It is the most respected text in both Sunni and Shiah sects. Although there are several differences between these two sects, both share the bond of the Koran.

To understand the roles of women in the Islamic countries, studying the Koranic rules about them is necessary. Mohammed himself had a lot of respect for women and made their situation much better than it was before.

Koranic Rules About Women. The Muslim lives by the Koran, from the first rituals of birth to the principal events of life and death, marriage, inheritance, business (including contracts): all are based on the Koran. 12

In this section an attempt is made to derive from the Koran those suras which are related to women's roles and their responsibilities in the family and society, their cooperation and contact with related men and others, also its attitudes towards women and men.

As a matter of fact, the Koran orders are the same for women and men--it blames them the same, rewards them equally, and prohibits them 
alike. All men and women in the Koran are God's creatures and there are no differences between them at all. Have a look at this sorah and see what God says about people: "Oh people, I created men and women . - but most dearest and closest to me are those that are most virtuous and fear God; God is aware of everything."13

Also, the Koran does not reproach Eve (Hava) any more than Adam to blame for the fall from Paradise, like other religions do. In any case, both were responsible for whatever happened in the Garden of Eden. Both were equally subjected to temptation, equally victimized, and remorseful. $^{14}$ For the treatment between men and women, the Koran says: "The believing men and the believing women owe loyalty to one another, they enjoy noble deeds and forbid dishonor, they perform prayer, and pay the alms, and obey God and his messenger. On them God will have mercy; God is All-Mighty and All-Wise."15

The normal principle behind the marital roles allocated to a wife certain rights, which are the husband's duties and corresponding obligations, which are his right. Because the Koran and the Prophet have commanded kindness to women, it is the husband's duty to consort with his wife in an equitable and kind manner. A specific consequence of this divine command is that a husband is responsible for the maintenance of his wife, a duty which he must discharge cheerfully without reproach or injury. Her right to maintenance is established by authority of the Koran, the Prophet, the unanimous agreement of jurists and reason or common sense. It is inconsequential whether the wife is a Muslim or nonMuslim, rich or poor, maintenance entails the wife's incontestable right to lodging, clothing, food, and general care. This rule must be 
observed jointly in a way that is equitable, moderate, and humane. For example, the husband must provide according to his means. The wife's expectation must be in line with her life style. The lodge must be so adequate as to ensure her privacy and comfort. 16

In addition to her right of maintenance, the wife has other rights of both an economic and moral nature; she is entitled to a symbolic marriage gift or endowment (dower) that is hers exclusively. This may be prompt, deferred or divided by mutual agreement. This is only a logical application of her rights as a whole person capable of and entitled to private enterprise and independent acquisitions. The fact is that Islam took this position almost fourteen centuries ago while none of the women in other religions had such rights.

From a moral standpoint, the Koran commands every husband to treat his wife with equity, kindness, and consideration. This is especially so when there is a co-wife. She has the right to be treated impartially with due consideration for her feelings and security. She may not be shown any aversion by the husband or subjected to suspense and uncertainty. No man is allowed to keep his wife to hurt her or hinder her freedom. If he has no love or consideration for her, she has the right to demand freedom from the marital bond and the law allows her to start a new life. 17

The wife also has a corresponding obligation to her husband. Her duty is to attempt with her best to make the home comfortable and secure for her husband, to make him happy, successful, and blissful in the marriage. Most specifically, she must be faithful, trustworthy, and honest. She must not deceive her mate and deprive him of legitimate progeny. Also she must not allow other people to have access to her 
husband's rights; i.e., she must not accept other men's gifts or entertain them in her home without her husband's permission or knowledge. Moreover, the wife should try to make her companionship more desirable and gratifying, because if she does not try to do so the husband has the right to interfere with her freedom to remedy the situation.

The Koran says: "Men are in charge of women, because Allah hath made the one of them excel the other, and because they spend of their property (for the support of women). So good women are the obedient, guarding in secret that which Allah hath guarded. As for those from whom ye fear them. Then if they obey you, seek not a way against them. Lo! Allah is ever High Exalted, Great."18

"Ye who believe; enter not houses other than your own without first announcing your presence and invoking peace upon the folk thereof. That is better for you, that you may be heedful."19

"Tell the believing men to lower their gaze and be modest. That is purer for them. Lo! Allah is aware of what they do."20

In the case of women's appearance in public and the veil, the Koran says:

And tell the believing women to lower their gaze and be modest and to display of their adornment only that which is apparent, and to draw their veils over their bosoms and not to reveal their adornment, save to their own husbands or fathers or husband's father, or their sons or their husband's sons, or their brothers or their brother's sons, or their sister's sons or their women, or their slaves, or male attendants who lack vigor, or children who know naught of women's nakedness. And let them not stamp their feet so as to reveal what they hide of their adornment. And turn unto Allah together, believers, in order that ye may succeed. 21 
God's order for women and men is the same, as follows:

Lo! Men who surrender unto Allah, and women who surrender, and men who believe and women who believe, and men who obey and women who obey, and men who speak the truth and women who speak the truth, and men who are humble and women who are humble, and men who give alms and women who give alms, and men who fast and women who fast, and men who guard their modesty and women who guard their modesty, and men who remember Allah much and women who remember Allah hath prepared for them forgiveness and a vast reward. 22

About women's contact with men there are limitations, as follows,

in the Koran:

It is no sin for them (the wives) (to converse freely) with their fathers, or their sons, or their brothers, or their women, or their slaves or women! Keep your duty to Allah. Lo! Allah is witness over all things. 23

- . prophet! Tell thy wives and thy daughters and women of the believers to draw their cloaks close around them (when they go abroad) that will be better, that so they may be recognized and not annoyed. Allah is ever forgiving, merciful. 24

These Koranic orders show that women in that period of time were not secure and safe in public so the orders came to protect them.

The Koranic suras show women's duties and status, according to Islamic rule. Indeed, Islam brought a lot of respect for women, whereas before Islam they were denied all rights, especially in the Arab world from which Islam rose; for example: The husband could marry as many women as he wanted, but Islam limited it to four, if he could be just and observe that he was treating them the same way; if not, one wife was enough. Baby girls were often buried alive after birth, but Islam prohibited this. Women were not allowed to inherit from their father in the Arab world. However, Islam gave them the right to inherit. Generally, contrary to other religions of the time, Islam insists on absolute respect for women. Islam looks to men and women equally, only 
says that men are one degree higher than women because they have to support them with their money. Since men have to support women for everything according to their family style, for this reason they do not like their wife, sister or daughter to have a job outside the home. On the other hand, according to the Koranic rules that were already quoted, women should be separate from men and should not have any contact with them, except their very close family men. It was another reason why men did not like women having jobs outside the home. For these reasons the outside world was a man's world and it was not good for the family's reputation for women to work outside the home. Indeed, at that time there was no need for women to work outside the home, especially in the cities.

The laws and regulations stated in the Koran, 1400 years before, were the state-of-art in preserving respect and protecting women's rights. For the time, such statements were extraordinary and unexpected from that part of the world.

It is interesting to note that the statement in the Koran can be interpreted in different ways, depending on the interpreters' views and attitudes. As stated before, this is another reason why there is dissimilarity in women's status among different M.E. countries. Also previously mentioned is the fact that religion is not the only factor that affected women's status. Tradition and custom had additional pressures over women and made their social life different in most M.E. countries.

As a result, according to Koranic rules and also tradition and custom, a public appearance by women was frowned on, for it was 
considered unnecessary for them to be outside the home. Even if there were a need to be outside the house, they were required to receive permission from either the father or husband; in the absence of these, from an older brother. On occasion, when a woman was allowed to go outside, it was imperative that she wear a black cover called a chador or veil. She was also required to wear a type of gaiter, called chakhchura, in some M.E. countries, such as Iran and Turkey. (A picture is illustrated in the Appendix, p. 101.) It created a lumpy foot. As well as these oppressive garments, a thick black or white veil with two holes cut out around the eyes, called robarden, was necessary. The purpose of these garments was to hide the woman's face and figure from public exposure and protect her from the eyes of men other than her relatives.

\section{Summary}

Hence the factors that prohibited women from having outside jobs were as follows:

1. According to the Koranic rules, men have to support their womenfolk and provide them a comfortable life.

2. According to the Koranic rules, women should not have any contact with the opposite sex, except first degree male relatives.

3. According to the Koranic rules, women's appearance in public was not reputable for their family and if it were necessary for them to be out they should not be recognized, so they were required to be veiled and completely covered. 
4. According to tradition and custom, outside work for females was not respectable in M.E. countries and it would damage the reputation of males.

5. Traditionally, men believed that women's outside jobs would bring immorality and immodesty to society and result in an unstable family life.

6. In fact, there was no need for women having outside jobs in the past thirteen centuries because the lifestyle was so simple and the needs and wants were not extended as is the case today for the majority of people. Thus men could handle the cost of the household by themselves or with the help of other family men.

So it should be noted that the most important factors among those that have been mentioned above are religion and tradition. In fact, those are the basics for other factors in women's status.

Although women were prohibited from having jobs outside the home, they had skills and knowledge for tasks (other than domestic jobs) that could be done at home. In this way they could also help their husbands. These hand jobs will be discussed specifically later in this study. 


\section{CHAPTER III}

\section{WOMEN'S ROLES FROM THE SEVENTH TO THE TWENTIETH}

\section{CENTURY HISTORICALLY}

\section{Introduction}

Women's roles (jobs, career, and business) were basically similar throughout thirteen centuries from the seventh to the beginning of the twentieth century in all M.E. countries. During the last part of the nineteenth century the industrial revolution, ${ }^{25}$ which had already happened in Western countries, began to affect M.E. countries. In fact, the industrial revolution had an essential effect at the beginning of the twentieth century and brought a lot of changes 1 ater.

This chapter will discuss generally and historically the role of women regarding their education and tasks they traditionally performed in M.E. countries through thirteen centuries. There was no notable variation in the case of women's education or tasks in the countryside, but this differed in the cities and villages of each country.

\section{Women's Education Before Changes}

From the Islamic point of view, education and study are necessary for everyone, women and men. As the Prophet said: "Seeking knowledge is a duty for every Muslim, men or women" or "Request knowledge from birth to the death." So the right to be educated, recognized by law, is also the duty to learn, for male and female. But in spite of the 
teaching of Islamic rule, women were prohibited from education by conservatives and prejudiced people. The women's world was dark, diminished, and limited to home and housework. Regarding men's education, there were no obstacles for them to be educated. When a man wanted to learn, he could go to study in any kind of school there was in that time, but this freedom was not for women because conservatives who had power during those days believed that education for women would ruin them and make them immodest and disobedient. Moreover, traditionally, in that period of time families believed that women did not need to be educated because their job was domestic work and education about that work was not necessary, since the girls could learn from their mothers at home. Indeed, the women were subjected to being a sexual object to their husbands, having and raising children, being a good housewife and devoted mainly to their families. Generally, women were hidden by the veil, segregated at home, dominated by men, and especially prohibited from education, except reading of the Koran, almost without understanding its meaning. Hence there were some Koranic schools, called Mactab or Kottah. The schoolmaster (Moallem) sat on a mattress, and his pupils (sometimes including little girls up to about age six, along with boys) sat opposite him on the floor. But since those schoolmasters generally possessed little knowledge themselves, and used no elementary textbooks except part of the holy Koran in Arabic, most of the pupils seldom acquired any competence to read and write. Those Koranic schools served primarily as places where children could be supervised and kept out of mischief. This task was fulfilled through the use of corporal punishment and torture. Then those boys who were interested 
in extending their knowledge and education could attend and gathered in a mosque, where classes were held. The instructor sat on a raised platform and the students circled around him sitting on the floor. Each circle was known under the instructor's name. He taught theology, religion, and Gnosticism. It was believed that the students should have general knowledge of matters of interest such as theology, religion, and Gnosticism. For this reason instructors were also required to have a vast knowledge of the above-mentioned subjects. Instructors selected their best students for their assistants and then as replacements for them if the instructors got tired of teaching or after their death. Those students interested in arts and sciences did their research and studies in their spare time. In the late eleventh century, some M.E. countries established better schools; for example, in Iran, KhajehNezam-Almolk, the Prime Minister of the Saljughid dynasty, opened schools called Nezamieh in different cities, including the most famous one in Baghdad. 26 All well-known instructors were graduated from Nezamieh Baghdad during several centuries. Unfortunately, women had no opportunity to attend any of these schools during these periods. In spite of the darkness of life for women who were not informed from outside of the home and were isolated in a conservative atmosphere in that time, some sympathetic and intelligent men in some of the M.E. countries, who were disbelievers of the religious propaganda that women should be forbidden to widen their mental horizons, secretly brought tutors home to teach their women languages, science, literature, and the Koran. Most of those tutors were reliable, elderly private tutors who were admitted to some of the homes of the aristocrats. Usually in such 
cases much weight was given to the reading of difficult classical works, the Koran, and calligraphy, which was regarded in nobles' families as an appropriate accomplishment for girls; also, learning Arabic and composing poems was important in those families. Compared to the population of women in M.E. countries, the number of these women was very small. Also, in the king's and ruler's palace, there was a special section for the king's wives, daughters and sisters, called the harem, where no male could enter except the king, his sons, and his father. The presence of a religious instructor was necessary in the harem to give the inmates lessons on religion and to organize or facilitate their performance of ritual duties. To the extent of her ability, the instructor also taught and trained them to write and read. Some of those tutors were learned and accomplished, especially in calligraphy. Sometimes women learned from their fathers, brothers or husbands, so the women in higher classes of society could be educated in the field of religious law, theology, and composing poems. But these occasions were only for a few women who belonged to the rich and enlightened families. It was like a few flowers growing in a dried and dark desert; in other words, women were in darkness, busy with their housework or stereotyped and wasting their time talking with other women about their families, children, cooking, and so on. Education and outdoor jobs were exclusive to men and women were not informed about what was going on outside the home. Although women were in a dark world, whenever there was a chance for them they had shown their capability and efficiency in their society where they belonged. A discussion will follow about some women whom historians have named as famous and talented. These women, from upper 
class society, had the chance of an education. Although the number of them is not great compared to the whole female population, the small group is the best evidence of women's ability and efficiency, even though denied by conservatives and religious peoples.

Poets, Scholarly and Learned Women. In that period of time when women were forbidden from education, in spite of all segregation, there were some famous and well-known women in the field of religious law, literature, and Gnosticism. Historians mentioned their names with a lot of respect. Also, most of the other scholars believed them and used their texts and ideas in their classes and their books. Some of these noted women are as follows:

Al-Khansa: She was the most famous of women poets, a contemporary of the prophet. Her life bridged the old days and the coming of Islam. She was an independent character, chose her own husband (at that time no Arab woman could do that), and had already written most of her poetry before she came with a delegation of her tribe to Medina to embrace Islam. She took part in the poetic competition of the day and held her own with the men. At one of these competitions a rival said, "We have never seen a better woman poet than you." She replied, "Don't you want to say that I am the best poet, male or female?" 27

Rabiah Bente-Kaab: This woman was one of the famous Gnostics, also a poet. Most of the great poets mentioned her name as a learned person in their books. 28

Mahasty Ganjavi: She was also one of the scholarly women in the eleventh century in Iran. When she was only 19 she was expert and skilled in music, and was known as the queen of poets, scholarly and 
learned persons. When she was only four years old her father provided her the best educated tutors to teach her. When she was ten years old her talent was exceptional and at the age of twenty she was well known and famous in her time. Historians registered her poems as the best samples in their books. 29

There were a lot of women poets in the Islamic period and before changes in the M.E. countries. One of the most famous was Parvin Eatesami. She was known as an excellent poet who had written revolutionary poems and thoughts, especially about women's freedom and their equal rights. 30

Rabiah-al-Adawyyah: This woman was known as one of the greatest religious, scholarly, and wise persons. Historians say that the Muslims got two-thirds of their religious instruction from that famous woman. She was seven when she learned and memorized the Koran. When she was fifteen people came to her school from all over the Muslim countries to learn the faith of Islam. There were always 500 students in her class, all of them Islamic teachers in their homeland. 31

Rabiah Omi Salameh: She was one of the Gnostics and learned women. The King of Kerman (Mohammed Shah) ${ }^{32}$ visited her and invited her to teach Gnosticism in Kerman. Most of the Gnostics and learned people were her students and had come to her to learn more from her class. 33

Since in this research there is no room for mentioning more wellknown women, the few named in each field serve as a good example for women's talents and abilities. 
Women's Jobs and Skills Before Changes

As stated previously, for centuries women were uneducated in general, restricted to the home and busy with housework. Some of them had skills in limited manual arts, such as weaving valuable rugs and carpets, tailoring, decorating clothes, pillows, napkins, scarves, signboards (tableaux), and purses with needlework and embroidery; also weaving shoes ( 1 ight cotton summer shoes), woolen jackets, scarves, gloves, hats, stockings, bed covers, clothes and dresses.

Moreover, women in the villages and on farms, who were and still are the majority of women's population in most of the M.E. countries, were more active. They had more participation in farm tasks. They planted tea, rice, and crops, and harvested them in some parts of the M.E. countries, such as the northern part of Iran. Milking cows and sheep, gathering wood, bringing water, making bread, cheese, and yogurt, cooking, washing, cleaning the house, taking care of the children, were specifically women's jobs in the villages.

There were some respectful jobs for women such as midwifery, matchmaking, teaching the Koran in maktah or kattah (old Islamic school), and women's beauty tasks. Also there were women rouzehkhan or religious reciters of sad events.

There was a variation in one country regarding women's status; for example, in some of the northern cities in Iran around the Caspian Sea, women worked side by side with men on farms; also among tribes women worked and still continue to do so outside their homes and tents, whereas in other parts of the country no one would see even the shadow of a female, whose only job was domestic tasks and some manual arts. 
Women in High Positions. Although there was a lot of discrimination between women and men, one in a closed and dark world and the other in an open and sunny world, whenever there was a choice and a chance for women, they were shining and glorifying in their society and did their job as well as the best men could do it, so that historians registered their names as heroes. These women proved their abilities and appeared "as brave men." As rulers, they kept their country free from danger; as leaders, they became famous and respected, so that their names are recorded with a lot of pride and honor.

It has already been mentioned that some women from bright and enlightened families or royal and aristocratic families used to be educated by private tutors during the Islamic period. Among those families had risen famous women, some from respected religious families. They had a business and supported their husbands, brothers, and sons. Some others kept their countries from danger; some were famous for their knowledge. Now a few of these women will be introduced as shining stars in a dark sky.

Khadijah: Khadijah belonged to the leading Maccan tribe of Quraish, and was twice widowed. In spite of the limitations for women in her position, she was able to open and run an import-export business, send her caravans to and fro, and employ agents and managers. One of these Khadijah chose to marry. His name was Mohammed, who later became the Muslim Prophet. He was twenty-five years of age and she was forty. They lived together for fifteen years until her death. Khadijah not only was a loving wife but was a strong supporting woman. Mohammed could not have succeeded in his mission without her indispensable support. 34 
Zainab: At the tragic massacre at Karhela, a city which is in Iraq now, it was a woman who was with her brother Hosain (Third Shiah's Imam) in the battle to the end. Her courage and energy saved the life of Hosain's children, especially one of them, who was carrying the line of the Prophet. It was Zainak whose name has been registered in the Shiah Muslim history as a hero. After her brother was killed by Umayyad Kaliph, it was her speeches that brought revolutionary thought and resulted in overcoming Abbasid. 35

Khaizuran and Zubaidah: These two women were famous queens of Abbasid Kaliph, who graced the courts of Caliphs during the first century of the Islamic calendar. Khaizuran was a slave who by her beauty and wits won her way to be the wife of the Caliph and mother of subsequent Caliphs.

Zubaidah was Haron Abrashid's wife (the most famous Caliph). Both of these women were influential in the affairs of their time, were patrons of art, and generous benefactresses. Khaizuran was the most politically ambitious, and Zabaidah the best remembered for her provision of fresh water supplies on the pilgrim road to Mecca. Both of these women exercised their greatest power, especially when their sons were ruling the Islamic world. 36

Seyyedeh-Khatun: This noted woman lived in the twelfth century in Iran. Her son inherited the kingship from his father when he was only nine years old, so the administration was taken over by his energetic mother, Seyyedeh-Khatun. When she was ruling in Ray, a part of Iran (in the central section), another conquered ruler called Mohammed Ghaznavi, the ruler of the Northeastern part of Iran, wanted to attack her and 
suffer the consequences, but she wisely prohibited him and changed his decision by sending him a message. She ruled safely, powerfully, and honestly. 37

Banoturkan: After her husband's death, Banoturkan was chosen as a ruler in the south of Iran (Pars) at the beginning of the thirteenth century. Her name is registered as a wise and powerful ruler. When the Mongols wanted to attack Pars, she wisely saved it and its people from their aggression and violation. She was assassinated, and after her death the Mongols came to Pars and killed those responsible but they did not sack the area out of respect for her.

Historians say that Banoturkan was one of the best and most powerful rulers in that period of history. She was wise, honest, modest, and ruled the country at the worst time in history. ${ }^{38}$

Shah-Bano-Khatun: This remarkable woman was the seventh ruler of the Ghara-Khatai dynasty, local ruler of Kerman in Iran, in the thirteenth century. Shah-Bano-Khatun was scholarly, just, modest, brave, and a hero. She was a good rider--even better than men in hunting, riding, shooting, and in battle. During her time Kerman had progress--agriculture and trade were prominent. People were secure with a comfortable life in the period of her time. ${ }^{39}$

Fatimah Khorasani: She was one of the greatest persons in the Mongol period in the thirteenth century in Iran. She had a profound influence upon the administration and her orders were as the king's orders. She was a great help in the welfare of the country. 40 
Makh-dom-Shah: This person was one of the most powerful and famous women, alongside her son, Shah Shuja, at the beginning of the fourteenth century in Iran. She defeated her son's enemies and supported and helped him in several different ways. 41

Khare-al-Nisa-Bagom: She was Tahmasb's wife and mother of Shah Abbas "the Great" (he was the Shah of Iran). This woman was one of the greatest politicians and a capable woman in Iran's history during the Islamic period. Khare-al-Nisa-Bagom administered the country when her husband was away, and proved her efficiency and capability to the nation. She had many followers, and finally became ruler of the country. This woman fought with the ottoman and Tatar Turks, designing the battle plan by herself and fighting at the front of the army during the war. She defeated the ottoman and Tatar armies, thereby getting a lot of booty and control of all the cities which the enemy had previously taken.

Consequently, the Tatar opened the door of friendship with Iran after that battle and became united with Shah Bano, the King of Iran. 42 She was ruling part of the country at the end of the sixteenth century and helped her son to become one of the greatest kings of Iran.

Shajarat-al-Durr: This famous woman was an administrator, a diplomat, and a brave person in Egypt, who was chosen among great political men and became the ruler of her country in the period of time when her society, as other M.E. societies, looked towards women as inferior. She ruled her country with great capability and efficiency at a time when nobody believed that a woman could be so brave and active. She had a leading role in the drama of the overthrow of Ayyubieds in Egypt. As a slave of Turkoman origin, she was bought from the Caliph of Baghdad by Salah-al-Din, the King of Ayyubieds' dynasty. He loved her and married her, but when he died, she took control of a desperate 
situation. Her followers by her leadership defeated their enemies and installed the queen as Sultan (King). Coins were struck in her name and peace ruled the 1 and. But this arrangement of a woman acting as Sultan did not meet with approval in Baghdad, and when asked to confirm the appointment, the Caliph wrote: "Since no man among you is worthy of being Sultan, I will come in person and bring you one." So the queen unwillingly retired and a soldier was appointed. 43

Queen Arwa-al-Sulaihi: This queen ruled thirty years in Yemen during the period of the Fatimids. Her long reign in Yemen had more local significance, but her story is remarkable in history. ${ }^{44}$

\section{$\underline{\text { Summary }}$}

Women's status in the long period of time (almost thirteen centuries) in the past was as a passive group who had been hidden by the wall, whose lives had been dominated by men. They were prohibited from education; they had only a choice of learning to read the Koran and religious rules if they were lucky. Generally, outside jobs did not belong to women. Even going outside the home was a difficult task for them (especially in cities) and required permission from the males of the family. For a wife, permission from her husband was needed, and for a sister and daughter from father or older brother. It was necessary to be veiled with a black garment. They should have no contact with a male except the closest family male (but not in public). Women's jobs were domestic ones and included handmade arts, which were the most valuable arts in the world, like beautiful rugs and carpets that were produced by women's hands in the cities, villages, and tribes, but the profit belonged to the men, because they were the ones who could carry them to the market and sell them. 
Women in that period of time were accustomed to their lifestyle, there being no other choice for them. They learned from mothers to be a good obedient wife for their husband and their only wish was to be married, because marriage was the most important event in their life-for the family too--the sooner the better, then having children. The reason for this was that a childless (barren) woman was not a lucky woman; almost always they had a miserable life because they were supposed to accept another wife for their husband to bring him children and live with them.

Indeed, there were some exceptions for women, like those who appeared in those centuries as leaders, learned scholars, and poets, al though they were the best evidence to prove that if women had a chance and a choice they could do important jobs as well as men. Women have talent and energy, too, but they need training.

The factors that prohibited women from being educated were not only Is Ian and Koranic rules because Islam and the Koranic rules persuade women and men to get an education and knowledge and there was no limitation in being educated according to Islamic rules. The restrictive factors for women's outside jobs were at first tradition. It reflected on religion, so this was the second factor. The third factor was the economy because there was no need for an extra workforce. The fourth was lifestyle, which was so simple that one of the family members could handle it alone, and it was traditionally the male responsibility. 


\section{CHAPTER IV}

WOMEN'S ROLES AFTER CHANGES FROM THE BEGINNING

OF THE TWENTIETH CENTURY UP TO 1982

\section{Introduction}

Invention has brought a lot of changes to the world. The industrial revolution was one of those events that changed lifestyles in most places from the middle of the eighteenth century. This revolution brought the need for manpower, skills, and knowledge in each place it occurred. The need for manpower invited women for jobs outside the home, and the need of skills and knowledge made women get the necessary education and skills. They became efficient and performed the same jobs that men did, but with lower salaries. In 1848 , French women participated in the French Revolution ${ }^{45}$ and asked for equal rights. Women in England and America followed suit. Finally, they obtained some equal rights. Later, women raised their voices in other Western countries, and by joining together they became more liberated and able to participate in their society.

Later, at the beginning of the twentieth century, industry and techniques affected the other continents, such as Asia and Africa, to an extent. The lifestyle started to change there,too. Among these changes was included the status of women in M.E. countries, because of the new need for skilled and educated workers. But these needs had an impact on the tradition, culture, and Islamic religion, regarding 
women's education and especially their jobs outside the home, so the progress of change has been slow and varied in those countries. Changes in women's clothing and appearance in Iran are illustrated in the Appendix, pp. 101-111.

\section{Factors of Changes Regarding Women's Status}

The factors that brought changes to the M.E. countries may be listed as follows:

1. The trade between the West and the East.

2. New ideas.

3. Governmental policy and support.

4. Economic sources, such as oil revenue.

5. Colonial impact.

6. The need for manpower.

7. Compulsory education and new educational systems.

8. Compulsory unveiling.

9. New techniques.

10. Women's movement in Western countries.

11. Travelers, newspapers, magazines, and movies.

12. Writers and poets.

Indeed, each of these factors could be discussed in more detail and also are worth good titles for separate investigations, but in this research they only needed to be listed.

Women's Education and the Percentage of Their Educational Enrollment

The first need for changing lifestyles was education. For women who were in a dark and neglected world for centuries as the result of 
culture, religion, tradition, and economic reasons, the changes were very difficult--also for families and society as a whole to accept. But those factors that previously were mentioned caused some enlightened people to provide education in the form of a few private female schools. Students of these schools were from the upper class of society. Later, some laws were passed on behalf of women's education by the government, such as compulsory education for both sexes. Still millions of girls of primary school age had no access to learning, despite compulsory education. Most of the M.E. governments hoped to achieve universal primary education by the year 1980. All of them failed, except two or three.

Primary Education: According to a study about women's education in the Arab world by Samira Harfoush and Kathy Sullivan ${ }^{46}$ in 1980:

In spite of the significant increase in female enrollment ratios at the primary level throughout the Arab world during the last decade, only Lebanon, Libya, and Kuwait achieved full female participation in primary education. Egypt has only 56 percent of its girls of primary school age enrolled, compared to 83 percent for the combined total of boys and girls in this age group. In Yemen, only 6 percent of school age girls are enrolled in primary education.

Problems in achieving full participation include insufficient school facilities, especially in rural areas, a shortage of teaching staff to handle growing numbers of primary school age children; and poor enforcement of compulsory education laws.

\section{Secondary Education:}

The percentage of females in secondary education has improved to 23 percent in 1950, 25 percent in 1960, and 33 percent in 1975. Female secondary student ratios range from over 50 percent in Kuwait and 40 percent in Jordan, to only one percent in Yemen. 
In Kuwait, Bahrain, and Qatar women achieved equal access to academic secondary education as the result of increased oil revenues and small population.

In most countries, one-third of all students in academic secondary level are female with the exception of Yemen where only one in ten high school students are female. ${ }^{47}$

Most families in the M.E. countries still think education is not necessary for girls, so they try not to send their daughters to school. If they do they almost always withdraw them from school at the age of puberty. The factors that make the percentage of female students low in some M.E. countries are as follows:

1. Family's traditional beliefs.

2. Family's economical problem--that they prefer their sons to be educated first and provide their educational expenses.

3. Early age marriage for girls in most of the M.E. countries.

4. Failure to implement compulsory secondary education for girls, and a shortage of girls' schools and female teachers for primary and secondary schools as well.

5. Government economic problem. Table I presents the percentage of female enrollment of all students by the level of education from 1965 to 1975 .

Vocational Education: Vocational education is not a favorable education for students, especially for girls in the upper and middle classes in most M.E. countries. Only in the last decade has the number of students in vocational fields increased in those countries that had a longer history of female education, such as Egypt, Tunisia, Lebanon, Syria, and Iran. 


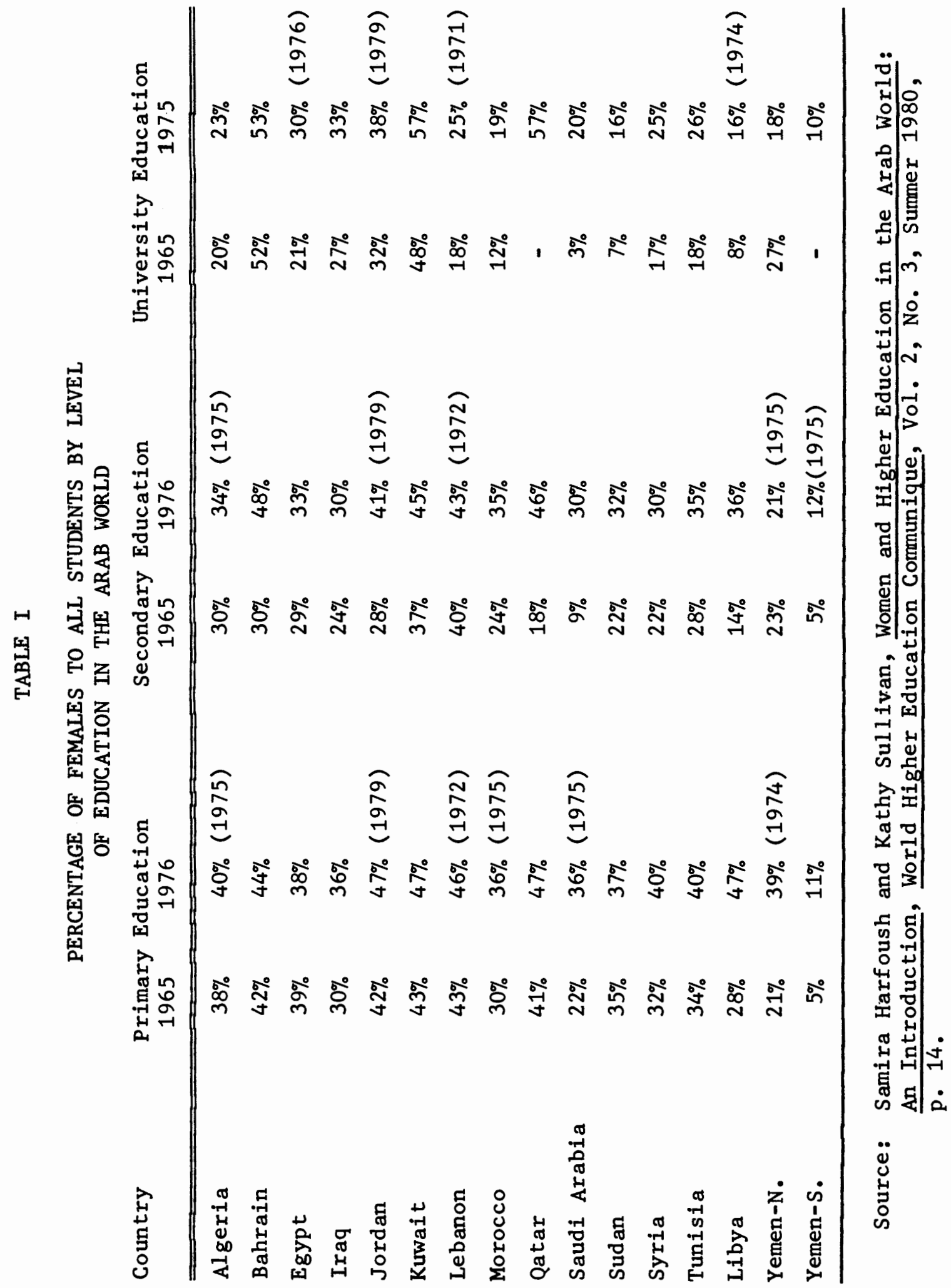


The number of female students in vocational fields in the five above-mentioned countries is much lower than in academic secondary or teacher training fields. According to a study by Samira Harfoush and Kathy Sullivan, "In 1977 Egyptian and Tunisian females represented 34\% of the total vocational school enrollments. But females' access to vocational education is almost nonexistent in Saudi Arabia, Yemen, Kuwait and Libya." 48

In M.E. countries which do have vocational education for women this training does not necessarily prepare them for active participation in their nation's economies. Emphasis has traditionally been on nursing, home economics, child care, sewing, and other handicrafts with some economic value. But Egypt, Iran, Tunisia, Lebanon, Jordan, and Morocco have expanded vocational education to include commercial and laboratory technician training. Morocco currently has a project to integrate women into previously all-male commercial and industrial training institutes. Presently, more Moroccan women are being trained with men in electricity, electronics, drafting, commercial accounting, and business management, than before.

In Jordan, women are enrolled in the secondary commercial section, but still have no access to the industrial and agricultural sections. Those women who are in the commercial section are enrolled primarily in secretarial and clerical skills rather than in management. Traditional female courses, such as garment-making, continue to have predominantly female enrollments. Commercial secondary education is attracting large numbers of M.E. women in countries where it is offered. 
Higher Education. Samira Harfoush and Kathy Sullivan stated in

their study that:

Arab female enrollments in higher education increased

from 6,000 in 1950 ( 12 percent of the total enrollment)

to 28,000 in 1960 (17 percent of the total enrollment)

and to 237,000 in 1975 ( 28 percent of the total enrollment). Increased female participation has been greater in some OPEC countries, such as Kuwait and Bahrain, which have almost the highest percentage of female enrollment in the Arab world. 49

According to 1975 World Bank statistics, the percentage of female participation ranged from a high of 30 percent in Egypt to a low of 1 percent in Yemen in 1976. In 1975, the majority of the Arab states accommodated between 4 and 10 percent of their college age population, compared to the world high rate of 58 percent in the U.S. ${ }^{50}$

The percentage of female enrollment in institutions is noticeably lower among the rural and lower class families. They face many more obstacles, limiting their access especially to higher education--like early withdrawal from school, lack of family support, early marriage, traditional family beliefs.

Field of Study: In M.E. countries, most of the female enrollment is in the field of social sciences, medical sciences, especially nursing education, and humanities, where the ratio of women is higher than male. But they have a lower percentage in the fields of natural or physical sciences, engineering, law, techniques, and political sciences. The case is in the Harfoush and Sullivan study as follows:

In 1975-76 women represented 71 percent of all students in the humanities in Kuwait and 20 percent in Libya, the highest and lowest figure for this field.

Percentage of female compared to all students in Arab higher education is 22 percent in humanities, 15.7 percent in education, 1.7 percent in fine arts, 6.1 percent in law, 24.4 
percent in social sciences, 7.8 percent in natural sciences, 4.7 percent in engineering, 11 percent in medical sciences (including nursing), and 5.5 percent in agriculture.

Al1 of Qatar's and most of Bahrain's female university students are enrolled in education. The next largest female's field is nursing. Egypt, Iraq, Tunisia, and Syria have the highest female enrollments in these two fields. Egypt, Iraq, and Syria are the countries with the highest female enrollments in agriculture. 51

\section{Women's Education in Iran}

The key factors in the movement towards equal status within society are education and employment. Both of these factors contribute to a breakdown of the traditional segregation of the sexes.

Before the twentieth century, women in Iran, like their sisters in other M.E. countries, were deprived of education. As mentioned before, only a small number of women were educated or could read the Koran, so that altogether their numbers were not noteworthy.

After the First World War, the number of ministers, editors, and writers, who were sympathetic to women's freedom, grew and these people swayed many minds with their deeply moving verses and encouraged some enlightened men and women to found some female private schools in big cities. However, they were faced with problems caused by conservative people in the locality, who began to stir up opposition. Several times school signboards were removed or stones thrown at them or at girls who wanted to attend the school.

In 1874, a group of American Christian missionaries, who had been sent to Iran, opened a school for girls and boys in Teheran. For a long time only Christian and foreign girls were admitted. In 1890 , only one Iranian girl was studying in this school. However, with this exception, 
no Iranian girl attended this school until in 1918 when other private girls' schools were started.

Another institution which arose during the struggle for constitutional government was the Franco-Persian (French and Iranian) School. The founder was later to play an important part in the history of Iranian girls' education because of his own two daughters' education. Private girls' schools established by enlightened families later on increased in number and size. In 1921, women teacher training was officially established. In 1925, the schools' doors were opened for girls officially, but it was not easy for them to attend school free from the effect of traditional and conservative ideas in society. It needed time for people to change their minds and accept and believe that girls needed to be educated. In 1930, the first midwifery school was established. In 1936, women were allowed to get a higher education and 12 girls attended the university at this time. At the same time compulsory unveiling of women occurred. On the other hand, compulsory primary education also helped a number of girls' schools and the number of female students increased more rapidly than before. ${ }^{52,53}$ From 1925 up to 1978 the legal and social position of Iranian women has changed dramatically.

It should be noted that Iranian laws, like the laws of other Islamic countries, are interwoven with Islamic law, so that any changes in the legal situation of women ran the risk of offending some of the religious leaders, who have a strong influence on the masses. This means that changes have to be effected diplomatically and even on occasion covertly by the government, so legally elementary education was 
compulsory by the government for all children, male and female. Many schools were built to actualize the law. For villages where schools and teachers were available, parents often prevented their girls from going to school. For instance, in 1974, in a village in western Iran, only 14 percent of the girls 7 to 14 years of age went to school, while 46 percent of the boys did. In a village of Southern Iran in 1971 about 57 percent of boys aged 6 to 19 were educated compared with about 19 percent of girls of the same age. The reason for preventing girls from going to school ranged from the unavailability of female teachers to the need for the girls' labor at home and to the belief that girls do not need an education. The belief is that a girl is to become a wife and mother. This goal requires knowledge only of domestic tasks, and hence education for the female is wasted time and money. In cities and towns, girls and boys were treated more equally than in the villages. For instance, in Pars it appears that 75 percent of the girls and 84 percent of the boys of the age 6 to 19 range are educated in town. The similarity and equality of male and female enrollments were more in Teheran in 1975. Each year the percentage of female attendance at schools became larger from 1960-1978. The increasing number of females enrolled in all levels was noticeable year by year. On the whole the increase of female enrollment pointed to an increasing acceptance of education for girls.

In $1956,7.3$ percent of the girls over 10 years of age were educated, while in 1966 this figure increased to 16.5 percent. This was even much higher (28 percent) in 1978. 54 
Education at the university level was also becoming increasingly popular for girls. The 1973-74 university census showed that about 30 percent of those attending universities all over the country were female. However, males and females enter rather different fields of study; for example, fields such as psychology, literature, history, and languages have a higher total female enrollment--almost 34 percent; that of the male, 14 percent, while such fields as engineering, political science, medicine, law, national development, and agriculture have a higher total male enrollment--about $48 \%$; that of the female, about 6 percent. 55

According to Ruth F. Woodsmall's study in 1960 , there were 3,573 schools with 319,923 male and 104,209 female students at pre-university levels in 1947-48, but these numbers dramatically increased each year. As Woodsmall's study shows, eight years later, in 1955-56, the number of schools increased to 6,791 , male enrollment jumped to 587,573 , female enrollment became 334,815, and in universities there were 7,299 male students but only 801 females enrolled in the same year. ${ }^{56}$ This study makes clear that women's enrollment almost tripled in the preuniversity level during eight years. It increased more even at the university level year after year up to 1978 . When the revolution occurred in 1979, education stopped increasing because of changes in values, system, and lifestyle.

Table II illustrates the number of schools and the male and female enrollment for the years 1947-48 and 1955-56 in the preuniversity level.

Table III shows the enrollment of boys and girls in the University of Teheran in 12 fields separately in the year 1955-56. 


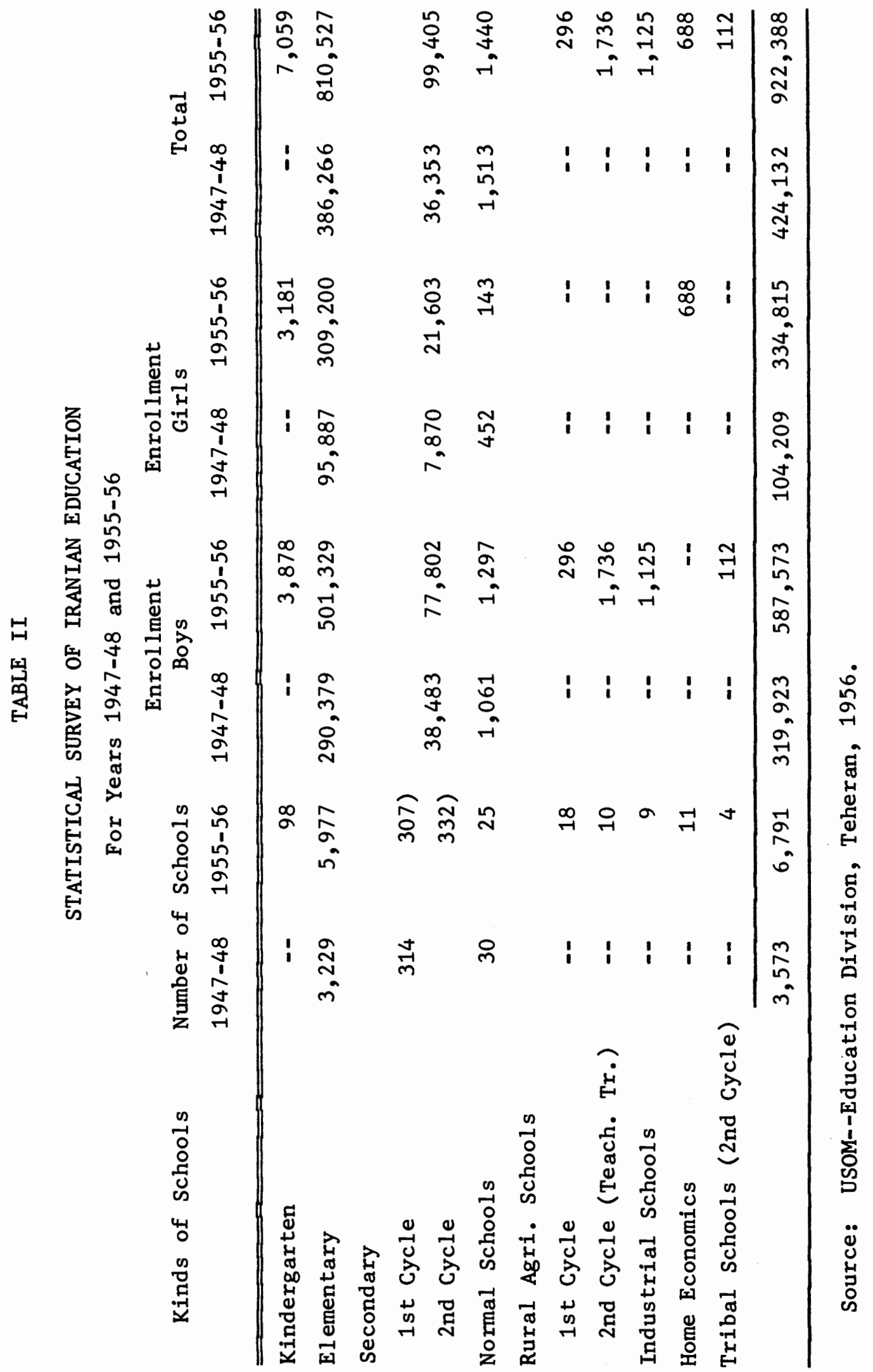




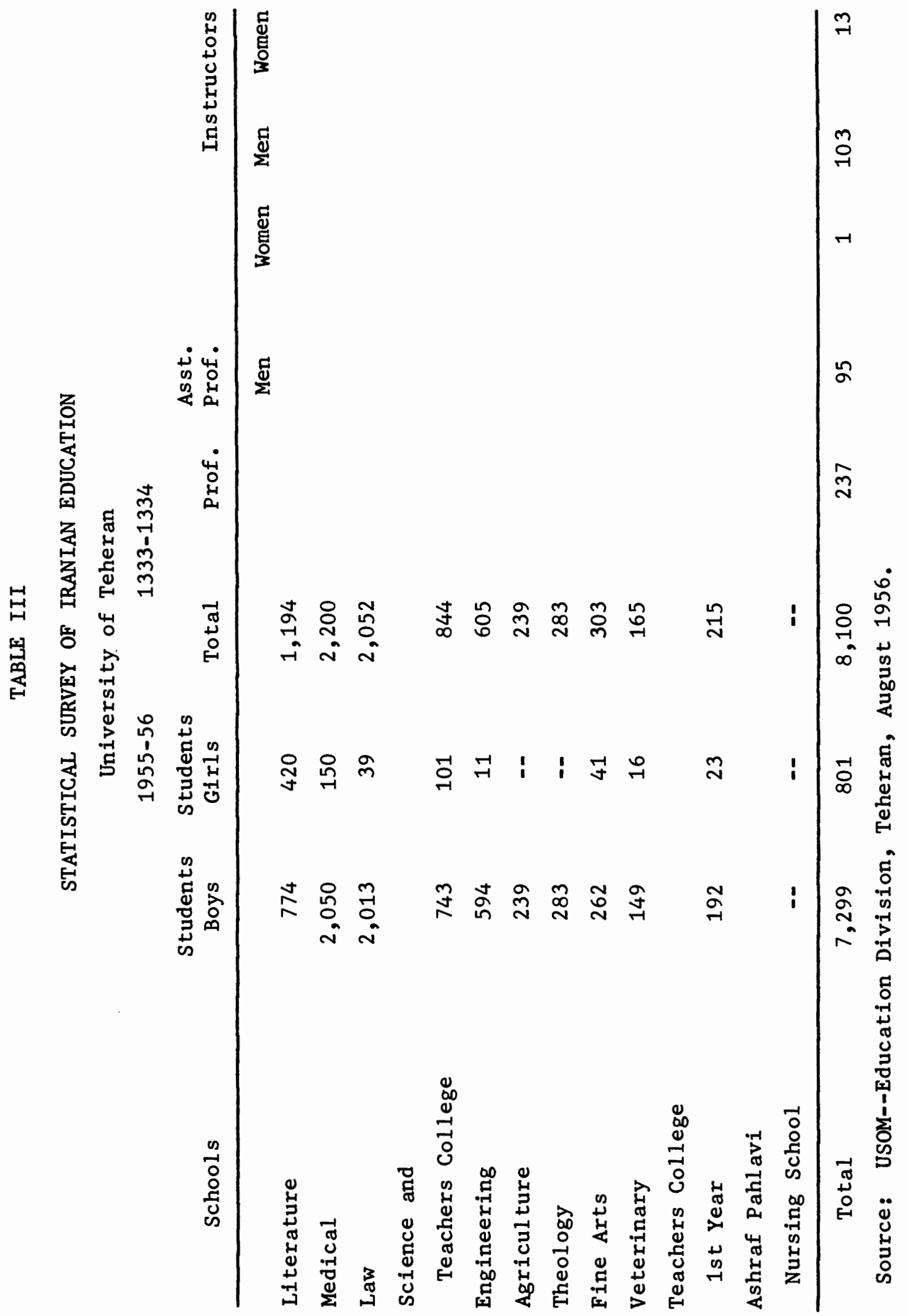


According to the World Survey of Education:

Total enrollments in educational institutions at all levels were $1,243,855$ students in $1957-58$ representing about 6.5 percent of the total population in Iran. There were in addition about 227,000 adults attending literacy and evening school courses. Girls made up about 31 percent in primary schools in 1957-58, compared with 28 percent in 1953-54, and in general secondary schools 26 percent against 24 percent in 1953-54. At universities the proportion of girls rose from 8 percent in 1953-54 to nearly 13 percent in $1957-58.57$

Table IV illustrates the total number of student enrollments at each level separately and the number of female enrollment as well, from 1953-54 to 1962-63. This table shows the increase of female enrollment in each year. A glance at Table IV shows that after 11 years the number of female students in the primary level became three times more. In 1953-54 the number of students were 212,643 and it became 343,744 in 1965-66. In the secondary level the number jumped from 28,712 in 1953-54 to 189,708 in 1962-63. The increase after 9 years was six times more in the secondary level and it kept increasing dramatically for both sexes so in 1981-82 female enrollment in the university level was 3,839 . This number became twice as much with a count of 6,849 in 1964-65, and it kept increasing year by year up to 1978 when female students at all levels were significantly noticeable. 58

(A map of Iran is in the Appendix, p. 98.)

Women's Education in Egypt

At the end of the nineteenth century, modernization started in Egypt. At that time some enlightened families who were educated and had contact with Europeans started to educate their daughters by bringing a tutor to the home. In 1900, the first group of Egyptian girls obtained primary school certificates from what was then the only school available to them. Later came compulsory education and the doors of schools were opened to girls officially. Through 1921-22, the number of females in public schools was 24,316 , but only 43 of those were in secondary schools. Later, in 1954-55, as the World Survey of Education 


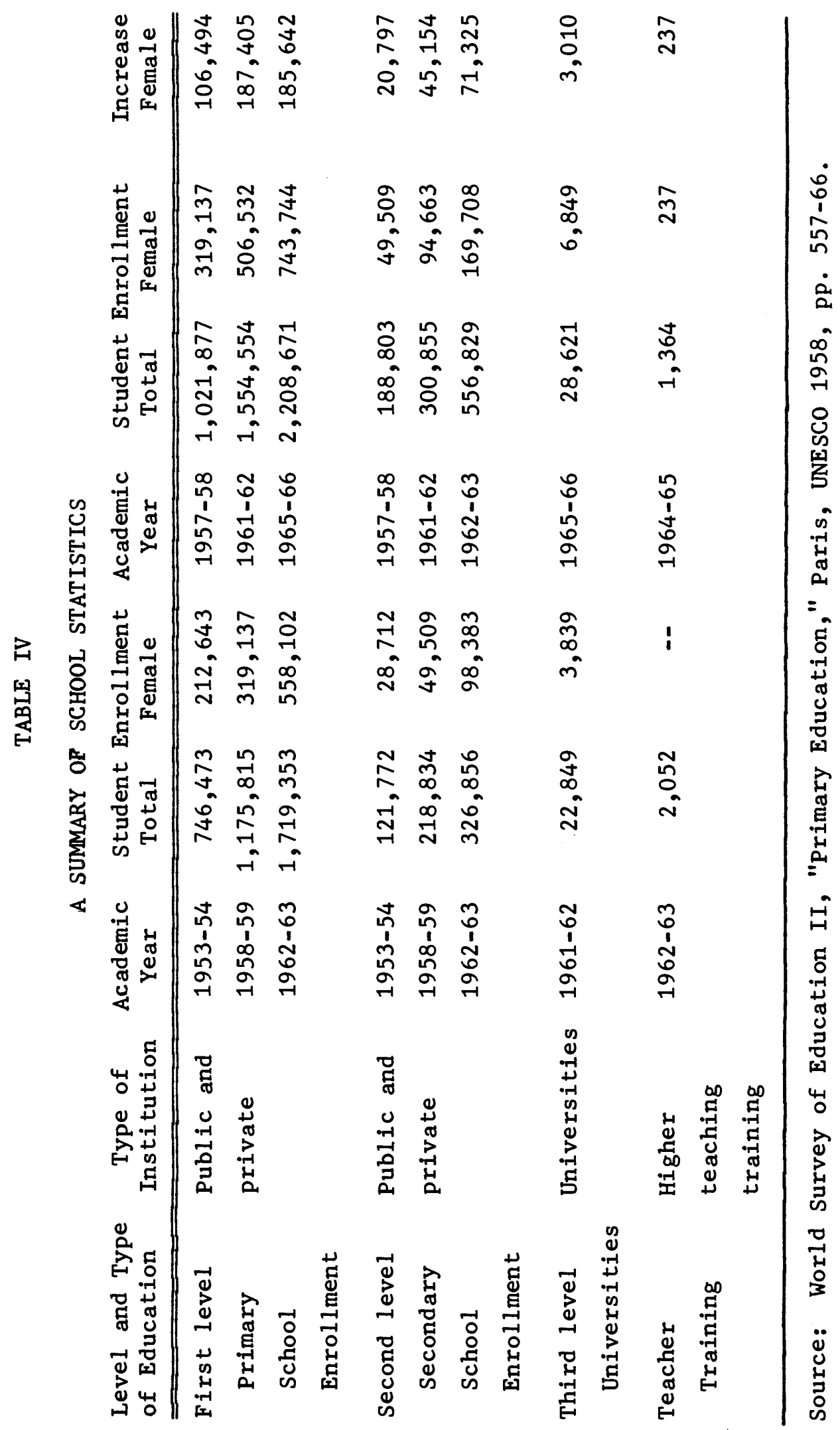


shows in Table $\mathrm{V}$, only 4,275 females were enrolled in preprimary schools but there were 14,122 male students in the same level. In the primary level, 468,971 females were enrolled, whereas there were $1,223,000$ male students in the same level. The number of female students in the public intermediate schools was 49,675 and in the public secondary schools the number was 15,213 , but the number of male students in those levels was 213,669 and 91,630 . Table $\mathrm{V}$ presents the increases in the female enrollment in all levels of education from 1950-55. In 1962, this number had risen to $1,154,454$ in public schools with more than 100,000 in the secondary schools and 20,000 in postsecondary institutions. In 1953-54, only 24 percent of all students in primary schools and 14 percent of secondary school population were female, but this percentage increased to 40 percent in the primary schools and 24 percent in secondary schools in 1961-62. The percentage of females in the university in 1952-53 was 8.4 percent. It increased to 30 percent in $1974-75$.

Indeed, these percentages increased to the higher rate year after year. In 1976-77, the Egyptian female population in primary schools was 38 percent; in secondary schools, 33 percent; in the university, 30 percent of all students in those levels. 59

But in the same year, Kuwait and Lebanon female students had the highest rate in education in the Arab world with 47 percent and 46 percent in primary schools and 45 percent and 43 percent in secondary schools. Kuwait had the highest rate (57 percent) for female students at the university in the M.E. countries. 
TABLE V

SUMMARY OF SCHOOL STATISTICS, 1950-54

\begin{tabular}{|c|c|c|c|}
\hline \multirow{2}{*}{$\begin{array}{l}\text { Level of Education } \\
\text { and Type of Institution }\end{array}$} & \multirow{2}{*}{$\begin{array}{c}\text { School } \\
\text { Year }\end{array}$} & \multicolumn{2}{|c|}{ Students Enrolled } \\
\hline & & Total & Female \\
\hline \multicolumn{4}{|l|}{ Egypt } \\
\hline \multicolumn{4}{|l|}{$\underline{\text { Pre-primary }}$} \\
\hline $\begin{array}{l}\text { Public nursery schools } \\
\text { Private nursery schools } \\
\text { Total } \\
\text { " }\end{array}$ & $\begin{array}{l}1954 / 55 \\
1954 / 55 \\
1954 / 55 \\
1953 / 54\end{array}$ & $\begin{array}{r}1,921 \\
12,201 \\
14,122 \\
\ldots\end{array}$ & $\begin{array}{r}607 \\
3,671 \\
4,278 \\
\ldots\end{array}$ \\
\hline " & $\begin{array}{l}1952 / 53^{\star} \\
1951 / 52 \\
1950 / 51\end{array}$ & $\begin{array}{r}109, \ddot{172} \\
84,030\end{array}$ & $50, \dot{35} \dot{4}$ \\
\hline \multicolumn{4}{|l|}{ Primary } \\
\hline $\begin{array}{l}\text { Public primary schools } \\
\text { Public upper primary schools } \\
\text { Private primary schools } \\
\text { Total } \\
\text { " }\end{array}$ & $\begin{array}{l}1954 / 55 \\
1954 / 55 \\
1954 / 55 \\
1954 / 55 \\
1953 / 54\end{array}$ & $\begin{array}{r}(1,223,000 \\
5,779 \\
251,094 \\
1,480,773 \\
1,395,729\end{array}$ & $\begin{array}{r}468,971 \\
1,663 \\
89,869 \\
560,503 \\
526,968\end{array}$ \\
\hline " & $\begin{array}{l}1952 / 53^{\star} \\
1951 / 52 \\
1950 / 51\end{array}$ & $\begin{array}{r}899,402 \\
1,390,520 \\
1,310,169\end{array}$ & $\begin{array}{l}190,549 \\
487,874 \\
466,684\end{array}$ \\
\hline \multicolumn{4}{|l|}{ Secondary } \\
\hline \multicolumn{4}{|l|}{ General } \\
\hline $\begin{array}{l}\text { Public intermediate schools } \\
\text { Public secondary schools } \\
\text { Private intermediate schools } \\
\text { Private secondary schools } \\
\text { Total } \\
\text { " }\end{array}$ & $\begin{array}{l}1954 / 55 \\
1954 / 55 \\
1954 / 55 \\
1954 / 55 \\
1954 / 55 \\
1954 / 55\end{array}$ & $\begin{array}{r}213,669 \\
91,630 \\
139,733 \\
16,819 \\
461,881 \\
440,636\end{array}$ & $\begin{array}{r}49,675 \\
15,213 \\
26,651 \\
1,586 \\
93,125 \\
85,365\end{array}$ \\
\hline $\begin{array}{l}\text { " } \\
\text { " }\end{array}$ & $\begin{array}{l}1952 / 53^{\star} \\
1951 / 52 \\
1950 / 51\end{array}$ & $\begin{array}{l}181,589 \\
151,188 \\
120,176\end{array}$ & $\begin{array}{l}25,990 \\
21,035 \\
15,453\end{array}$ \\
\hline
\end{tabular}

Source: World Survey of Education II, "Primary Education," Paris, UNESCO 1958, pp. 335-44.

* Reorganization of the educational system in 1952 affects the comparability of figures before and after this date. 
TABLE V--Continued

Level of Education

School

Students Enrolled

and Type of Institution

Year

Total

Female

Egypt

Vocational

Public technical secondary schools 1954/55

Public commercial, agricultural and technical schools

Private commercial and technical schools

Total

$1954 / 55$
$1954 / 55$
$1954 / 55$
$1954 / 55$
$1953 / 54^{*}$
$1951 / 52$
$1950 / 51$

3,441

17,220

569

"'

11
11

Teacher Training

Public teacher training schools

Public schools of physical culture

$1954 / 55$

$1954 / 55$

$1954 / 55$

$1953 / 54$

$1952 / 53$

$1951 / 52$

$1950 / 51$

1,154

21,815

21,615

569

-

495

29,369

26,001

25,371

1,103

1,024

Total

"1

11

26,841

12,169

578

309

27,419

12,478

24,204

11,344

20,282

10,048

13,148

5,724

9,883

4,520

Teacher Training

Public teacher training colleges
Total
"
"

$1954 / 55$

$1953 / 54$

$1952 / 53$

$1951 / 52$

$1950 / 51$

2,765
2,323
1,853
950
740

1,472

1,315

1,175 
According to the World Survey of Education, in 1958--

The proportion of Egyptian girls enrolled in primary schools was 38 percent, in secondary schools 20 percent, in vocational and teacher training schools 46 percent, at secondary level, and 53 percent at the higher level. In the other higher education institutions the proportion of women students was only 10 percent in the year 1950-51. There was in 1954-55 an increase in total enrollment and this tendency is relatively more marked in enrollment of girls.60

(Table $V$ shows the figure.)

$\underline{\text { Summary }}$

One of the several factors that changed women's roles was education. For centuries women in the M.E. countries were generally forbidden to be educated, but from the end of the nineteenth century little by little people woke up and accepted that women should be educated. Writers, poets, news, enlightened women and men, changes in the lifestyle, the need of manpower, the high cost of the new lifestyle, all of these factors brought awareness to most of the people that females should be educated as well. So the number of female enrollments in all levels of education increased year by year. The governments in most of the M.E. countries were not able and still are not to provide enough schools and necessary facilities and staff for them. The rate of female students in the big cities in all those countries is higher than in small towns in all levels. In the villages in those countries the number of female students is still much lower than male students, especially in the secondary schools and there is no access to university level. There are some countries that have the lowest rate for female education, such as Saudi Arabia and Yemen. The highest rate regarding female education belongs to Kuwait, 
especially at the university level. The factors that are obstacles for keeping this rate low in the M.E. countries are as follows:

1. Traditional and conservative beliefs in the families.

2. Lack of government support.

3. Lack of finding sources for government to provide more schools and train teachers.

4. Family economical problems. 


\section{CHAPTER V}

\section{WOMEN'S EMPLOYMENT AND WORKFORCE}

\section{Introduction}

In fact, the opportunities for employment that are available to educated women vary from country to country according to society's degree of traditionalism and such factors as a surplus or shortage of workers in various fields. In most countries, women are still channeled into traditionally prescribed roles due to the persistence of sex stereotypes and despite the advertisements of professional women as symbols of change.

So these factors have made the progress of women's activities outside the home very slow and kept the percentage of women in the workforce very low compared with women's participation and employment in the industrialized and developed countries.

The economy also has an essential duty in a society to provide more jobs for people, but regarding women's activities it has not brought this about as it has in the men's workforce in M.E. countries, because tradition and custom have more impact on society.

Percentage of Women's Workforce and the Relation Between the Economy and Women's Workforce Rate

As is stated before, the percentage of women's workforce in M.E. countries is varied and minimal compared with that of advanced and developed Western industrialized countries. It is even 
very low compared with the percentage in countries outside the M.E. which are almost similar in economic growth but have different social and cultural systems.

There is a comparison study between Latin America and the M.E. countries undertaken by Nadia H. Youssef in 1971. Youssef compared these two groups with respect to women's participation in the nonagricultural workforce. In fact, she has chosen two groups of countries which are roughly in similar stages of economic growth and are characterized by different social and cultural systems (Latin America is Catholic; the M.E. is Muslim). The study provides a unique opportunity to examine more closely the aspect of interrelationships between women workers, social structure, and economic development, as shown in Table IV. This table shows that regional differences in the women's workforce are striking despite the similarities in the level of development. In both groups the average of activity rates of adult males in nonagricultural workforce is 37 percent. By contrast, the corresponding average of the female rate is nearly 20 percent in Latin America and only 4 percent in the M.E. ${ }^{61}$ Table VI represents the case. The most significant finding in Table VI is that the female workforce in the most advanced country in the M.E. region is as low as in the least developed country in Latin America. Although Youssef's research has been done a few years ago, the women's social structure and labor force have not increased noticeably, especially in some of the M.E. countries, such as Saudi Arabia and Yemen. An exception is in the field of education and health workforce, where women have the highest workforce rate as teachers, especially in the kindergarten and primary schools, and as nurses in most of the M.E. countries. 
TABLE VI

COMPARATIVE DIFFERENCES BETWEEN FEMALE PARTICIPATION IN NON-AGRICULTURAL ECONOMIC ACTIVITIES IN SELECTED LATIN AMERICAN AND MIDDLE EASTERN COUNTRIES GROUPED BY DEVELOPMENTAL IEVEL c. 1960

(Data for population 15+)

\begin{tabular}{|c|c|c|c|c|c|c|c|c|c|}
\hline \multirow{2}{*}{\multicolumn{3}{|c|}{$\begin{array}{l}\text { Region } \\
\text { and Country }\end{array}$}} & & & & & \multicolumn{2}{|c|}{$\begin{array}{c}\text { Participation } \\
\text { rate }\end{array}$} & $\begin{array}{l}\text { Pct. } \\
\text { female }\end{array}$ \\
\hline & & & & & & & Male & Female & of total \\
\hline \multicolumn{10}{|c|}{ LATIN AMERICA } \\
\hline Chile . & • & - & - & . & - & - & 56.1 & 21.8 & 30.6 \\
\hline Puerto Ric & & - & 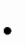 & - & 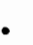 & - & 46.2 & 19.7 & 31.0 \\
\hline Costa Rica & & - & • & - & - & - & 40.9 & 16.3 & 28.9 \\
\hline Jamaica . & - & - & - & - & • & - & 40.5 & 35.7 & 50.2 \\
\hline Peru . & 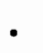 & . & 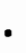 & - & - & - & 39.5 & 15.3 & 28.7 \\
\hline Ecuador. & - & - & - & - & - & . & 34.9 & 21.8 & 30.7 \\
\hline Mexico & - & - & • & - & - & - & 30.6 & 12.0 & 26.3 \\
\hline Nicaragua & - & - & 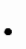 & - & - & - & 29.4 & 19.0 & 41.2 \\
\hline El Salvado & $\mathrm{r}$ & - & & . & . & • & 28.1 & 17.4 & 40.2 \\
\hline Honduras & - & - & 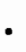 & - & • & - & 23.9 & 13.1 & 36.4 \\
\hline Average . & $\cdot$ & - & • & - & - & - & 37.0 & 19.2 & 34.3 \\
\hline \multicolumn{10}{|c|}{ MIDDLE EAST } \\
\hline $\operatorname{Iraq}$ & - & - & • & - & . & & 44.6 & 2.6 & 5.5 \\
\hline Egypt . & - & - & • & - & & • & 40.1 & 3.5 & 8.1 \\
\hline Iran & - & $\bullet$ & & 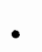 & 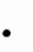 & 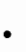 & 39.6 & 7.0 & 14.6 \\
\hline Morocco & $\bullet$ & - & - & - & - & - & 38.4 & 4.5 & 10.9 \\
\hline Turkey & - & 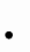 & 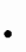 & - & & . & 36.4 & 2.7 & 8.1 \\
\hline Syria • & - & & & - & & $\bullet$ & 35.0 & 3.2 & 8.2 \\
\hline Tunisia. & - & & & - & $\bullet$ & • & 34.9 & 4.4 & 9.5 \\
\hline Pakistan & - & & & - & & • & 26.4 & 2.3 & 7.1 \\
\hline Average . & - & - & - & - & - & - & 37.0 & 3.7 & 9.0 \\
\hline
\end{tabular}

Sources: World Urbanization 1950-1970, Vo1. II, Analyses of Trend, Relationships and Development (Berkeley: University of California), forthcoming Rep., Dept. of Education and Social Affairs, Demographic Yearbook 1964; International Labour Office, Yearbook of Labour Statistics 1967 (Geneva: United Nations Publication 1968), 27th ed., Table 2A. 
These two fields account for over 96 percent of all women in professional technical categories.

Youssef presented another comparison with a group of five countries classified into industrialized and underdeveloped according to per capita income and activity rate of adult males in nonagricultural work. She has measured the female component in terms of women's work participation rate in the nonagricultural sector in Table VII that presents that the women's scores have a higher average participation in the advanced economics than they do in the newly developing nations. The mean female activity rate in the industrialized world is 28.1 percent and in the underdeveloped nations it is 12.3 percent.

However, comparing these rates, Youssef considered underdeveloped countries as a group. A closer look at individual cases among these gives cause to reject the notion of a consistently positive relationship between women's work participation in nonagricultural activities and the level of economic development. In certain underdeveloped nations, the female activity rates are as high as 36 percent, as in Jamaica; in others they are as low as 2 percent, as in Pakistan. 62

Youssef stated in her study:

The low level of female involvement in nonagricultural 1 abor force in the M.E. countries can be explained by the combined effects of tradition and religion on female seclusion and exclusion patterns. By seclusion patterns it refers to the volitional response of women to participation in public life, the personally motivated avoidance of certain public activities as distinct from exclusion, by which is meant the sanctioned prohibitions and limitations imposed by males. These cultural and traditional roles are reflected strongly in the social structure through institutional mechanisms operating to keep women from participating in public activities which brings contact with the opposite sex. 
TABLE VII

OCCUPATIONAL DISTRIBUTION AND INDUSTRIAI COMPOSITION

OF THE TOTAI NON-AGRICULTURAL LABOR FORCE: CHILE, MEXICO, EGYPT, MOROCCO AND PAKISTAN c. 1960

(Occupation data for population 15+; industry for population 12+)

\begin{tabular}{|c|c|c|c|c|c|}
\hline $\begin{array}{l}\text { Occupational Group } \\
\text { or Industry Branch }\end{array}$ & $\begin{array}{l}\text { Chile } \\
1961\end{array}$ & $\begin{array}{l}\text { Mexico } \\
1960\end{array}$ & $\begin{array}{r}\text { Egypt } \\
1960\end{array}$ & $\begin{array}{l}\text { Morocco } \\
1960\end{array}$ & $\begin{array}{c}\text { Pakistan } \\
1961\end{array}$ \\
\hline $\begin{array}{l}\text { OCCUPATION } \\
\text { All occupations: }{ }^{\text {a }} \\
\text { Number, thousands } \\
\text { Percent }\end{array}$ & $\begin{array}{l}1,584 \\
100.0\end{array}$ & $\begin{array}{l}5,257 \\
100.0\end{array}$ & $\begin{array}{l}3,044 \\
100.0\end{array}$ & $\begin{array}{l}1,135 \\
100.0\end{array}$ & $\begin{array}{l}7,139 \\
100.0\end{array}$ \\
\hline $\begin{array}{l}\text { Professional } \\
\text { Administrative/managerial } \\
\text { Clerical } \\
\text { Sales } \\
\text { Workers, mines } \\
\text { Workers, transport and } \\
\text { communication } \\
\text { Craftsmen/Wkrs., prod. } \\
\text { process } \\
\text { Service, sports, and } \\
\quad \text { recreation }\end{array}$ & $\begin{array}{r}7.5 \\
2.9 \\
10.2 \\
10.6 \\
3.5 \\
4.9 \\
40.1 \\
20.3\end{array}$ & $\begin{array}{r}7.8 \\
1.8 \\
13.2 \\
19.5 \\
2.1 \\
40.8\end{array}$ & $\begin{array}{r}7.1 \\
2.5 \\
8.3 \\
18.2 \\
0.4 \\
6.8 \\
35.7 \\
21.0\end{array}$ & $\begin{array}{r}8.6 \\
1.3 \\
5.5 \\
16.4 \\
3.1 \\
5.0 \\
37.0 \\
23.1\end{array}$ & $\begin{array}{r}5.8 \\
1.9 \\
7.6 \\
18.2 \\
0.3 \\
6.2 \\
45.8 \\
14.3\end{array}$ \\
\hline $\begin{array}{l}\text { INDUSTRY } \\
\text { Al1 industries: }{ }^{a} \\
\text { Number, thous ands } \\
\text { Percent }\end{array}$ & $\begin{array}{l}1,578 \\
100.0\end{array}$ & $\begin{array}{l}5,107 \\
100.0\end{array}$ & $\begin{array}{l}3,155 \\
100.0\end{array}$ & $\begin{array}{l}1,011 \\
100.0\end{array}$ & $\begin{array}{l}7,310 \\
100.0\end{array}$ \\
\hline $\begin{array}{l}\text { Extractive industries } \\
\text { Manufacturing industries } \\
\text { Construction } \\
\text { Electricity and gas } \\
\text { Commerce } \\
\text { Transport } \\
\text { Public and administrative } \\
\text { services (excluding } \\
\text { domestic) } \\
\text { Domestic service }\end{array}$ & $\begin{array}{r}5.3 \\
27.2 \\
8.6 \\
1.2 \\
15.3 \\
7.8\end{array}$ & $\begin{array}{r}2.8 \\
30.5 \\
7.9 \\
0.8 \\
21.1 \\
7.0\end{array}$ & $\begin{array}{r}0.7 \\
22.3 \\
5.0 \\
1.2 \\
20.0 \\
8.1\end{array}$ & $\begin{array}{r}3.8 \\
26.9 \\
5.5 \\
0.7 \\
23.5 \\
7.8\end{array}$ & $\begin{array}{r}0.3 \\
33.6 \\
4.7 \\
0.5 \\
20.2 \\
7.2\end{array}$ \\
\hline
\end{tabular}

Source: International Labour Office, Yearbook of Labour statistics 1967 (Geneva: United Nations Publications 1968), 27 th ed., Tables $2 \mathrm{~A}$ and $2 \mathrm{~B}$.

a--Computations exclude all economically active population classified in "Ill Defined" and "Unknown" categories. 
Youssef then stated that:

An important consideration in understanding female seclusion and exclusion from participation in public life is the criterion of family honor and esteem. This honor is determined above all by the sexual conduct of 'man's womenfolk: premarital chastity of the daughter and sister; fidelity of the wife; continence of the widowed and divorced daughter or sister. These are basic principles upon which a family's reputation and status in the community depend. On the other hand in most M.E. countries, since employnent for single girls is likely to reduce her chance of marriage; and for married women, an atmosphere of mistrust and suspicion, disruption of married life, eventual divorce or polygamy for the husband, has another great deterrent in keeping women's employment in the nonagricultural field so low.

There is another comparison for women's participation in the industrial workforce between the two countries, Chile and Mexico, in Latin America, and three M.E. countries, Egypt, Morocco, and Pakistan, which have similarities in their development and economy regarding women's activities: Chile has 21.8 percent; Mexico 12.0 percent; Egypt 3.5 percent; Morocco 4.5 percent, and Pakistan 2.3 percent. Table VII describes occupational distribution and industrial composition of the total nonagricultural labor force in the five abovementioned countries. 63

Women's workforce in domestic services is the female domain in Chile and Mexico, but in the M.E. countries, such as Egypt, Morocco, and Pakistan, it is the male domain because 70 to 80 percent of domestic servants are male and domestic services are served by male. In the manufacturing industries, the female proportion among all is only 5 percent in Pakistan, 35 percent in Morocco, and 2 percent in Egypt. Market labor is also the monopoly of men concerning all activities related to trade and sales occupation and the female proportion in these fields is not noticeable and has a very low rate. 64 
In fact, comparing M.E. countries with each other, the changes are varied. In some of them the changes are more rapid and more extended. The number of educated women has increased year after year, and female activities in various fields has jumped rapidly in the 1 ast decade. These countries include Iraq, Iran, Egypt, Lebanon, Kuwait, Morocco, Algeria, Turkey, and others.

Today, women in those countries have participation in the services, factories, industry, education, and many other fields as well. In some other countries, such as Saudi Arabia and Yemen, women's activities are limited to a few sectors, such as education and health.

Although there is a variation in the situation of women's roles and work participation in the M.E. countries, the basic roles, as stated previously, are the same throughout the Muslim M.E. countries. The important factors that have resulted from this variation are as follows: 1. The effect of tradition, 2. The power of governmental policy over religious and conservative elements, 3 . The effect of education and its extension among nations.

The Effect of Religion and Tradition on the Youth Attitude Towards Women's Roles

As stated before, the role of religion and tradition has imposed severe limitations on the public participation of women in M.E. countries. But today, changes in lifestyle, the fact of education, the force of governmental policy, the influence of new Koranic interpretations, and the effect of Western societies, have changed the attitudes toward the role expectation for women, especially among youth 
in M.E. countries. A comparison of boys' and girls' attitudes towards women's employment was undertaken by Peter C. Dodd in 1974 that clearly shows the youth attitude and the effect of religious affiliation towards the role of women.

Dodd emphasized sex role expectations on the norms that people hold for behavior of women. Most studies of these norms have been limited to the traditional sector of society. The interest in his research is on the norms held by educated youth. His research focuses on sex expectations held by individuals, both male and female, of differing religious affiliations. Since the level of education may well affect the sex role expectations held by an individual, he controlled this factor by surveying a restricted population, all of whom had the same level of education. On the other hand, he wanted to prove that tradition and customs of a society are greatly influenced by religion, so he tested two groups of young students with different religions. These students have a common educational experience, having come through the selective processes of the lower schools. The opinions that they express, especially at the secondary school level, often reflect the opinion of parents. It seems that also these opinions are more liberal than those of their parents, because most of the secondary school students have already attained a higher level of education than their parents. This study was done in Lebanon, where the oppulation is divided almost equally between Christians and Muslims (Sunni and Shiite, 57 percent; Christians, 40 percent). ${ }^{65}$ The study included schools in a wide variety of communities, with male and female students in the same proportion. The students' ages ranged from 17 to 23, with medians at 
18 and 19. They were in the age of maturity and were aware of the system of sex role expectations, rewards, and sanctions. Table VIII shows the pattern of responses and the youth attitudes on women's role by sex. It also shows that the pattern of responses obtained from boys differs markedly and systematically from that obtained from girls. In every item girls are more likely to favor a liberal response than are boys. Boys and girls differ most on working outside the home after marriage. Forty-nine percent of the boys agree with Item 2, and 79 percent of the girls. (Item 2: A woman should be able to work outside her home after marriage; and in Item 8: a) (Boys only) When you marry, will you approve of your wife working outside the home? b) (Girls only) Do you intend to work after marriage?) Fifty-nine percent of the boys approve of their own wives working outside the home, while 89 percent of the girls state their intentions to do so.

The norms held by boys differ from those held by girls. The sexes do not agree on appropriate roles for men and women in Lebanon any more than they do in other societies. In all cases the majority favored the changes that would permit women to work, to have a high position, to have authority over men, and to have equal pay.

Several results could be derived from Dodd's test in Table VIII. First, educated young females wanted to be more liberal and have outside jobs; second, young educated men more or less agree with women's emancipation; third, this liberal attitude among young males and females was derived from the effects of education; fourth, changes have more effect on the new generation, and it means that changes need more time to become more effective in general. 
TABLE VIII

YOUTH ATTITUDES ON WOMEN'S ROLE BY SEX

$\begin{array}{cc}\text { Boys } & \text { Girls } \\ (\mathrm{N}=425) & (\mathrm{N}=226) \\ \text { Percent } & \text { Percent }\end{array}$

Item

1. A woman should be able to work outside her home before marriage.

Agree

"It depends"

Disagree

Agree

"It depends"

Disagree

Agree

"It depends"

Disagree

Agree

"It depends"

Dis agree ministrative posts in industry and finance.

5. Men should never be under women's supervision.

6. A woman should be less educated and less cultivated than her husband.

7. A woman's duty is to raise children and take care of the household work.

8. a) (Boys only) When you marry, will you approve of your wife working outside the home?

b) (Girls only) Do you intend to work after marriage?

9. Suppose that men. and women are working in a factory and all of them are doing the same work. What pay do you think that each group should receive?
Agree

"It depends"

Disagree

Agree

"It depends"

Disagree

Agree

"It depends"

Disagree

Yes, full-time

Yes, part-time

No
81

2

17

49

1

48

27

2

70

70

2

28

39

1

59

16

2

82

73

2

25

7

52

41
100

0

0

79

1

20

55

1

43

79

0

21

30

0

61

9

0

91

46

1

52

17

72

11

$\begin{array}{lrr}\text { Equal pay } & 65 & 88 \\ \text { Women more } & 3 & 2 \\ \text { Men a little } & 27 & 9 \\ \text { Men much more } & 4 & 0\end{array}$

Source: Peter C. Dodd, The Effect of Religious Affiliation on Women's Role in Middle Eastern Arab Society, Journal of Comparative Family Studies, 1974 , p. 123. 
Dodd also tests students separately on the effect of religious affiliation to prove the depth of religion and tradition on girls' and boys' attitudes on women's roles. Table IX presents the Muslim and Christian boys' attitudes to women's roles.

The data in Table IX show no consistent pattern of differences by religious affiliation. The differences are modest in size, ranging from 0 to 14 percent. Item 7: A woman should raise children and take care of the house work--this is a traditional one. Most boys agree; most of them support the traditional role-definition; however, the Muslim boys are less 1ikely to agree (66 percent) than the Christian boys ( 80 percent).

Table $X$ presents a second test on the effect of religious affiliations on sex role expectations in the responses of the girl students.

The data of Table $X$ show that differences between Muslim and Christian girls are also slight, except Item 3. On the other eight items, four of them show a 1 percent difference; the other four are all less than 10 percent.

Item 3 has to do with the propriety of a married woman with children holding a job. It is striking that this item alone shows consistent differences in response between Christian and Muslim students, both boys and girls. The Muslim students, both boys and girls, are more likely to agree with this item than are Christian students. It is not clear whether this difference has any basis in religious teaching and doctrine. Both religious groups emphasize motherhood and the importance of child-rearing; neither forbids nor discourages work for women; both 
TABLE IX

BOYS' ATTITUDES ON WOMEN'S ROLE, BY RELIGION

(PERCENT AGREEING WITH THE ITEM)

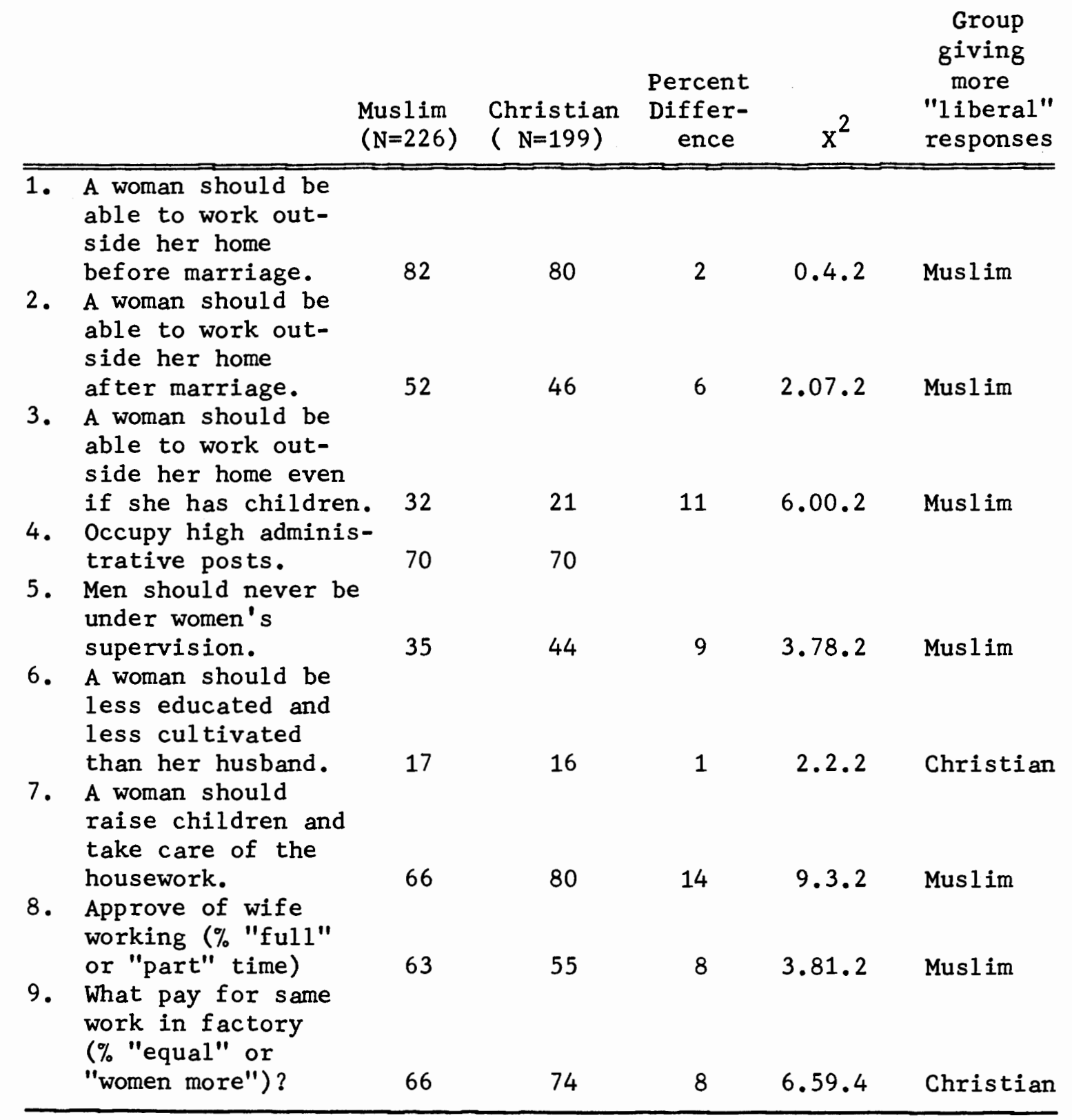

Source: Peter C. Dodd, The Effect of Religious Affiliation on Women's Role in Middle Eastern Arab Society, Journal of Comparative Family Studies, 1974, p. 124 . 
TABLE X

GIRLS' ATTITUDES ON WOMEN'S ROLE, BY RELIGION

(PERCENT WHO AGREE WITH THE ITEM)

1. Work before

marriage.

2. Work after marriage. 84

99

100

1

1.6 .2

Christian

3. Work, even if she has children.

65

77

7

Muslim

4. Occupy high administrative posts.

49

16

2.47.2 Muslim

5. Men should never be under women's supervision.

63

9

5.94.2 Christian

6. A woman should be less educated and less cultivated than her husband.

9

1

$$
.02 .1
$$

Christian

7. A woman should raise children and take care of the household work.

1

.06 .2 Christian

8. Do you intend to work after marriage (\% "full" or "part" time)?

88

3

2.06 .2

Christian

9. What pay for same work in factory (\% "equal" or

"women more")?

Source: Peter C. Dodd, The Effect of Religious Affiliation on Women's Role in Middle Eastern Arab Society, Journal of Comparative Family Studies, 1974, p. 126. 
enjoin modesty upon women. The responses of Muslim and Christian girls show similarity. Muslim boys ( 32 percent) are somewhat more likely to favor work for the married woman than are Christian boys (21 percent). As a result, the boys' responses to the items on sex-role expectations do not seem to show any consistent effect that could be attributed to religious affiliation of the nine items; only three showed significant differences. Of these, the Muslims were more in favor of women with children holding jobs and they were more opposed to the traditional "home and children" role definition for women.

Dodd has used the same questionnaire for girls of Muslim and Christian sects. Table $\mathrm{X}$ shows the results.

In this study, sex does make a difference and an important one. Girls wish to be more liberal; boys are more conservative; and it is the fact of getting and giving; women want to get more equal rights and have more emancipation, and men still are not ready to give up all the rights that they already have had for domination over women. So opposition to women's emancipation is stronger among men of the society than it is among women.

Dodd tries to show in this study that religious affiliation does not appear to have an effect on these attitudes regarding appropriate behavior for women, because Christian and Muslim students hold similar patterns of attitudes toward women's roles in society, so in one society religious affiliation does not appear to have an effect on these attitudes regarding appropriate behavior for women.

As a result, it is tradition that has a deeper effect on society and has overshadowed religion, thus constituting a great obstacle 
toward acceptance of changes by society as a whole. Comparing the last two researchers (Dodd and Youssef), Youssef in her research, as mentioned previously, compared different nations with different religions but with similar economic and development levels. She has tried to prove that economics does not have any deep effect on the female participation rate in the workforce. It is religion that has kept that rate so low in the Muslim societies. On the contrary, Dodd's attempt in his study is to prove that religion does not have as important an effect as tradition. He wants to prove that tradition which belongs to a nation has deep and strong shadows over religion those societies have. On the other hand, Dodd tried to picture the changes among the newly educated generation concerning women's roles and concluded that it needs time to effect these changes and this attitude extended through all kinds of groups in society. In fact, it should be noted that Lebanon, which was the basic source in Dodd's study, is completely different from other Muslim countries, because of its composition of 57 percent Muslim and 40 percent Christian.

These two groups of the Lebanon nation have a notable effect on each other in their society, and this situation has made a more moderate role expectation for women, especially among educated young people. Dodd's research about the attitude of youth could not be a sample for other Muslim countries, except for a few like Iran. But it is important to state that tradition has a strong influence over religion in most Muslim nations regarding women's role expectations. It is also the basic factor, which has brought variation in Muslim 
countries regarding women's roles. Tradition has a stronger effect in villages and small cities in each country, because it has not been touched by other factors which brought changes in the M.E. countries. So even women's roles differ in each city and village of each country. Certainly the attitude of youth regarding women's roles has changed and in most M.E. countries. It is more liberal than before, especially in the big cities.

This researcher interviewed some Muslim male and female students individually. All of the students in this interview were from upper and middle class in their society and were studying in the United States. This study proved that even being educated in a more liberal country could not change completely the deep effect of tradition which exists among most of the M.E. people. So the effect of tradition created a variation in Muslim countries regarding women's roles and their outside jobs and resulted in the highest and lowest rate in women's public activities.

The researcher interviewed at Portland State University and Portland Community College thirty Muslim male and thirty Muslim female students, from different countries, about women's roles (outside jobs). The questions were simple and short, as follows:

1. Do you agree with women's education and to what level? Female answers were 100 percent positive and male response was 65 percent positive. Most of the males who were from Iran, Egypt, Kuwait, and Lebanon were in agreement with women's education to a high degree and most of the males from Saudi Arabia were in agreement only with high school graduation or less. 
2. Do you agree with women's jobs outside the home before or after marriage, even when they have children? Female response was 55 percent positive for women's jobs before marriage, after marriage and with children. Twenty percent of the females were in agreement with women's jobs before having children and after the children have grown up. Twenty-five percent were in agreement before having children on one condition--if their family needed their support economically; but males' response was 75 percent negative and they were not in agreement with women's jobs outside the home. One of them, who was a student from Saudi Arabia and who had a sense of humor, told me, "A woman is created to be a good wife and be pregnant, raise children and make the home comfortable, warm, and suitable for her husband, and it is a man's responsibility to have an outside job, to fight with outside problems for making more money to provide a house, clothes, and everything for his wife and children." He added, "I wish I was a woman to have a comfortable life at home and a good supporter husband to provide everything for me."

Women's Jobs in Iran

Seventy years ago if foreigners visited Iran they seldom if ever met any Iranian women in public at all; they only knew that walking black bundles which they saw in some streets were women, because they were told so. But the constitutional revolution which started in 1906 and continued to 1911 was the most fundamental of the many great changes 
which have taken place in Iran, especially in the women's position. Women had greatly participated in the constitutional revolution; also many good writers and poets, who expressed sympathy towards women's emancipation, supported them by their effective poems and articles to enlighten the government and the people to change their attitudes towards the role of women. On the other hand, Western countries had already changed women's status and lifestyle. This situation affected other countries more or less. The most important one was the changes in Turkish women who were Muslim and who lived in the closest country to Iran.

In later years, after 1925, women were able to make fuller use of their energies and talents year after year by the constitutional government's support through legislation and laws. In 1925, women were permitted to be educated and then find ways to participate more in society. The factors, such as oil, wealth, a wise government, and better education caused more emancipation for women. In January, 1936, females were forced to become unveiled by government order. In the same year, they obtained the right to enter the university that already belonged only to males. For a period of time women's only jobs outside the home included teaching in girls' schools and nursing in hospitals in the women's and children's sections.

Later, women gained more positions in public. In 1963, women gained the right to vote and hold civic office as part of the white revolution that took place in the same year. Then women who were qualified had more participation in all kinds of jobs in the big towns and cities. Through 1965-79, women operated in high positions and on 
the level of decision-making and they obtained prestige jobs, such as professors in the universities, doctors, officers, lawyers, and so on. They could enter into all kinds of positions with equal salary if they qualified.

In 1963, there were four women in Parliament, two women senators, and one woman vice-minister. In 1972, there was a first woman minister and 18 seats reserved for women in the Parliament, two women in the Senate, and two women vice-ministers.

In 1975 , there were 10 women vice-ministers, one minister, and the first woman ambassador for the Persian Embassy in Denmark. Women had great participation in all kinds of affairs, except judgeships and army leaders, but their highest participation rate was in the teaching and nursing sectors.

Women's participation rate in the workforce was noticeable in 1979 compared to their public activities in 1930, for instance, but it was not comparable to women's participation in the Western countries, even those countries that had similar economical level conditions.

The changes in Iran were rapid in the big cities and provinces. Even women were beginning to enter occupational and professional roles in the more conservative cities as well. But women teachers, midwives, and bureaucrats operated in a world of children or women in those cities. Until 1975, education was still segregated by sex, and no women teachers taught in boys' middle and high school, even in the big cities like Teheran. Only women teachers operated in the private coeducational primary and middle schools in the capital of Iran (Teheran). 
In fact, the majority of the Iranian population are villagers, almost 75 percent. Half of this population are women villagers who work in the fields, tend the animals, milk the cows and sheep, and weave rugs and blankets, and do needlework.

Women in the tribes work side by side with their husbands, fathers, and brothers. Moreover, they weave beautiful rugs and carpets, which are the most valuable export item in the world.

In the cities, women have participation in all sectors in high and low positions. Tables $\mathrm{XI}^{66}$ and XII present women's activity rate and number in the Iranian workforce. Table XII presents the economically active group by sex and age. The total economically active population is $9,732,508$. Of that number $8,280,240$ are men ( 47 percent); $1,452,268$ ( 8.9 percent) of that active population are women. The highest rate is in the 20-25 age group, 17.9 percent.

Table XII presents the structure of the economically active population in 1976. It illustrates the number of employers and ownaccount workers, employees, and unpaid family workers in the mine fields. A glance at this table makes clear the number of active women in mine sectors, but the total number of women employers is 148,812 and the total number of women employees is 571,708. The number of women unpaid family workers is 471,646 compared to male activities in that year, which is 2,881,068 employers and 4,164,150 employees, and 571,988 unpaid family workers. So it is noticeable that males' activity is almost twenty times more than women's activities; only the number of unpaid family workers for male and female is very close to each other. 67 


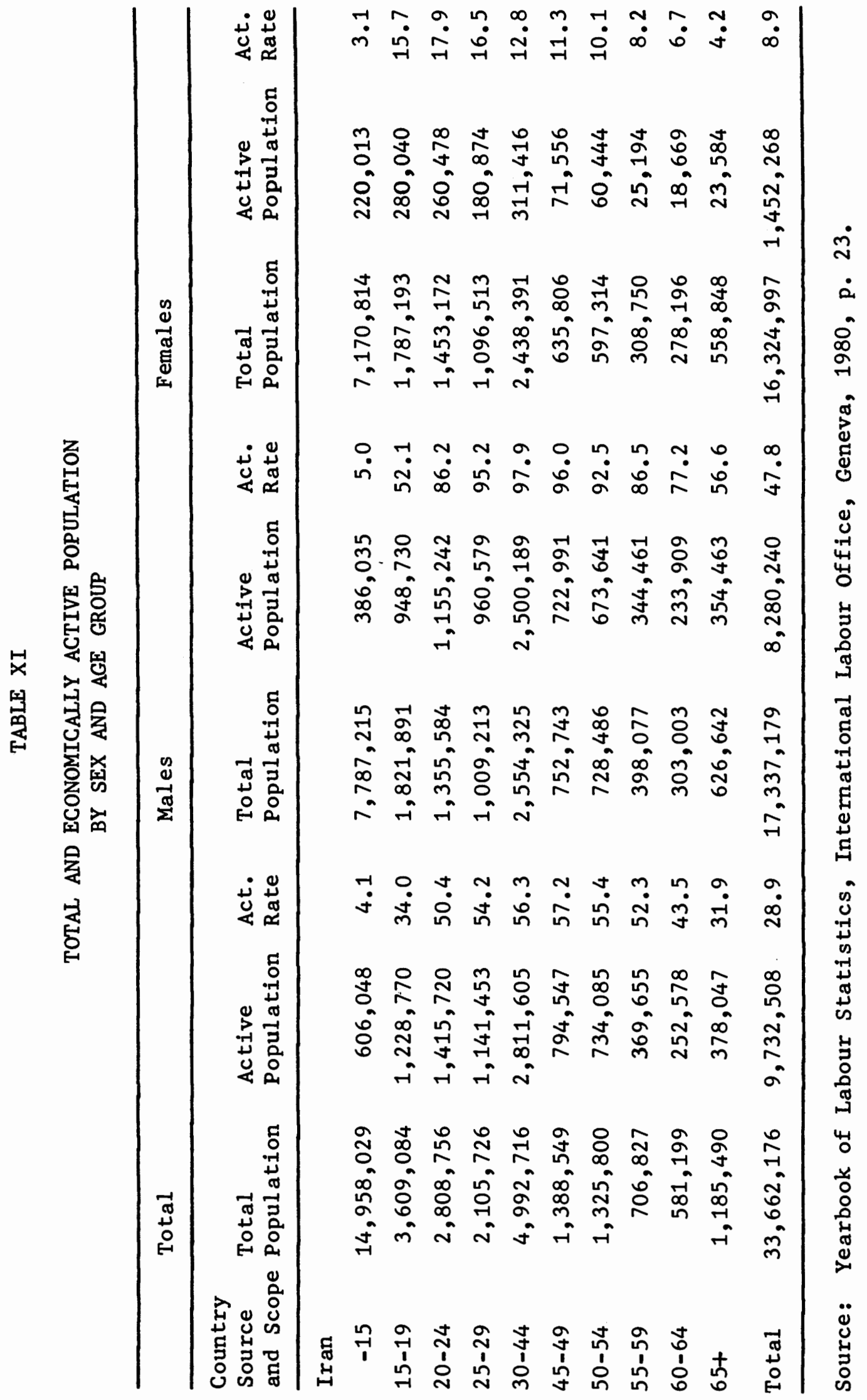


The changes in the women's roles were very rapid in Iran compared to those in most of the M.E. countries, but socially and psychologically many men did not like their wives to have jobs outside the home. However, the idea was becoming more socially acceptable. Although the rate of women's activities was low compared to that of men's activities, it still was one of the highest rates among M.E. countries, and was supposed to be higher each year and more acceptable except that some changes took place in 1979 that changed all the values. The picture of women in the various positions is illustrated in the Appendix, pp. 112-122.

In 1979, an Islamic revolution took place in Iran and changed everything. Indeed, in this revolution women had a great participation, hoping to get more equal rights, but the Islamic government disappointed them. They believe that women are created to be good wives, take care of the domestic jobs, and raise the children. They forced women to be veiled and have floppy and loose dark dresses in public, and be segregated from males. Men are persuaded by the government to marry more than one wife. A family protection law, which had made polygamy very difficult for men, was the first law that was cancelled by the new Islamic government.

A talented and scholarly member of this Islamic government, Dr. Mottahari, brought out his idea in his book about women's jobs. 68 He stated that there are three kinds of societies; that family society is one of them, which is natural, and an agreeable society. Male and female in this society are two different kinds of human beings, and their differences are not geographical or historical or social matters, but a matter of creation. The Creator has had a purpose for this diversity in adjusting to the natural life. 
Then he stated that in fact the voice of women's liberation at the middle of the eighteenth century in European countries was not a real voice; it was a trick from the owners of factories to get more profits from women's labor, which was cheaper. They preferred women because they could give them lower wages and get more obedience compared to the proud workmen. On the other hand, the production of the factories had been increased day by day and needed adequate consumers.

Finally, the factory owners found women good consumers on the one hand, and on the other hand they used their beauty and attractiveness in advertisements to interest people to buy their products. So the aim was not women's abilities and talents or women's liberation; it was a trick to have less expensive labor.

In this way Dr. Mottahari believed that women actually gave up their real liberation and became captured by the hands of the factory owners; it even cost more for the women because most of them gave up their purity and chastity, and as a result the foundation of the family became unstable and the divorce rate increased anywhere this situation occurred. He also believed that politics used women as an effective factor in several ways.

It could be derived from his book that outside jobs for women will ruin them and society and make the foundation of family life unstable. In fact, revolutionary leaders like Dr. Mottahari believe that women's first and most important job is to stay at home and do domestic tasks and provide a comfortable home for their husband and family; that it is men's duties to support them and their family and provide a simple life for them according to Koranic rules. 
Now women are forced to go back to the veil and be segregated from males. Females who still are working in offices have separate departments that have no contact with the opposite sex. If one of them does not follow this rule, she will be fired and treated badly. On the other hand, women in the women's tasks are very busy today, such as women beauticians, women tailors, female doctors, especially gynecologists, because the government wants women to have contact only with women for their tasks.

So Iranian women who had a great participation in the recent revolution, hoping to have more equal rights, lost most of the ones they al ready had and are faced with going back hundreds of years because of the fanatic and conservative government now in force. For sure, the rate of women's participation in the workforce has decreased not only because of those fanatical ideas, but also has decreased due to additional factors such as the high rate of men unemployed, the miserable economy, polygamy, and bad attitude towards women who work. In fact, this situation is causing suffering to enlightened and educated people, and it is painful for talented and educated women as well, but nobody can oppose the government because of its power of life and death over the people.

Women's Jobs in Egypt

There are several factors that changed the role of women in Egypt over the years. First of all was the contact with the Western world that was the beginning of changes and modernization from 1898 until 1922 (the Napoleanic and British rule). The second factor for change was the influence of many great reformists and writers, most of whom were 
educated in Europe, which had a tremendous effect on Egyptian society, especially for women's emancipation and roles. The third factor was the revolution against the British that happened in 1919 . Women had an important role and participation in that revolution and worked alongside their brothers, fathers, and husbands. The fourth factor was the attempt of women who were from the upper and middle class to obtain female emancipation. They established the first women's association in 1920. The fifth factor was the government's policy towards the role of women. This policy was not rapidly or easily achieved, but it did include offering free education for both male and female, which advanced women's education a great deal. The sixth factor was the high cost of living in big cities which made for cooperation of both husband and wife in the financial support of the family. This created support for working women. Then increased dependency on the income of women as a source of family support gave great impetus to changing the role of women.

In 1952, under pressure from the group working for women's right to vote, the Commission of Fatawi of Al-Azhar, the highest authority on interpretation of Islamic law and doctrine, issued a definitive fetwa or legal statement. The writers of fetwa rejected the right of women to vote and to serve in Parliament as incompatible with the spirit of Islam. They referred to the passage in the Koran which reads: "Remain in your homes and do not exhibit yourselves in public the way women in the time of ignorance did."

The Commission of Fatawi was forced by the Egyptian government to accept the reform of female role and then women were given the right to 
vote in 1956, but this conservative attitude still exists in Egypt. Despite this opposition, women's participation in public life has been quite noticeable in the last few decades because of government support. Thirty of 360 seats of the People's Assembly were reserved for women. Two women have become Cabinet members; and numerous others are occupying leading positions in the government and political structure in Egypt. Today, women in Egypt are working in most fields, except judgeships and district attorney positions. Anyway, women seem to be accepted fairly well in the public domain.

Al though there are opportunities for women having outside jobs, only 5 percent of all employees are female, whereas in Latin American countries, with similar economic situations, the female employee rate is 20 percent. It shows that cultural and traditional conservative ideas in most families, especially in small cities, prohibit women from having outside jobs and have a deep effect in keeping this rate so low.

Today, university education has become an acceptable pattern for women in Egypt, also work and employment have been accepted because of the increase in the cost of living, which requires the cooperation of husband and wife to support the household, so working women with an income are frequently sought after marriage. However, many people look with suspicion on educated women and seek an uneducated woman for marriage. Most of the men and their families prefer a girl with the maximum of a high school graduation for marriage. They think that they would have no control whatsoever over the affairs of the household if they marry a highly educated girl, and they feel more comfortable with 
an uneducated woman. It is because traditionally men like to be superior and be dominant over the house and family. This factor is also a basic obstacle to keeping the rate of female participation so low in Egypt. There are several tables that show the number and the rate of female activities outside the home among the total population. Table XIII presents women's participation and its number and rate in public tasks among the total active population in the years 1976 and 1978 . In the year 1976, the total active number of women is 983,546 ; that shows 5.5 percent of the total active population. Then this number is increased to the total number of $1,112,000$ with the percentage of 6 among the total active population in 1978.

Table XIV presents the general level of employment from 1970 to 1978. The total female population in 1970 in this table is 514,700 and 743,300 in 1978. Table XV shows the number of employed persons in nonagricultural sectors. The female participation in this sector in 1970 was 387,500 ; it then increased to 651,900 in $1978 .^{69}$

Table XVI presents employment in manufacturing from 1970-1978. Female activity in this sector in 1970 was 85.4 (in thousands); that of male activity in this field, which was $1,126.3$ (in thousands), is not comparable. It rose to 797 (in thousands) in 1978.70 This table shows that women's participation in the workforce increased year by year, but it should be noted that women's participation in Egypt is not comparable to women's participation in the workforce of other continents outside of the M.E. It needs time to change and moderate the attitude towards women's work outside the home in societies like Egypt and others. 


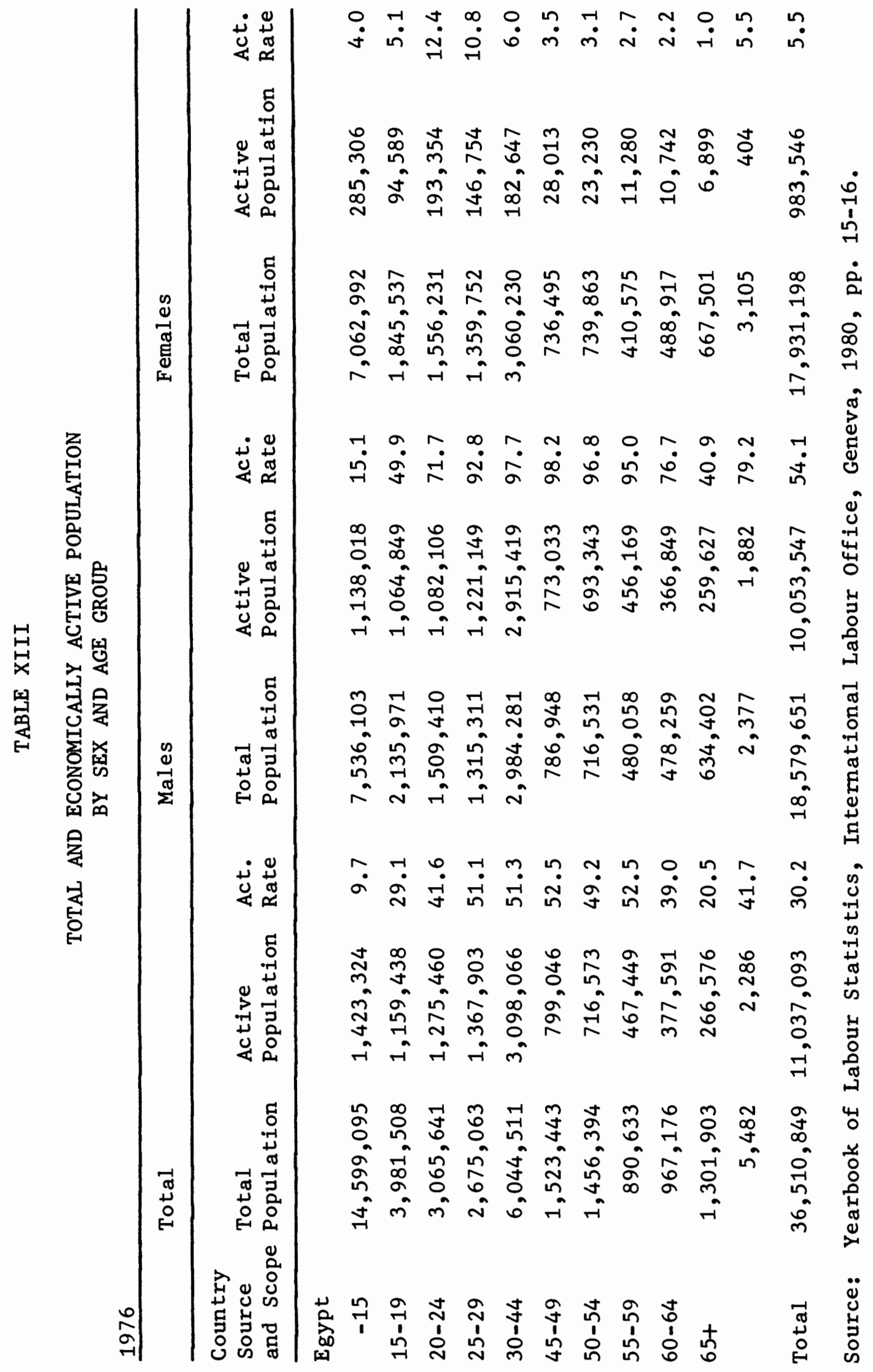




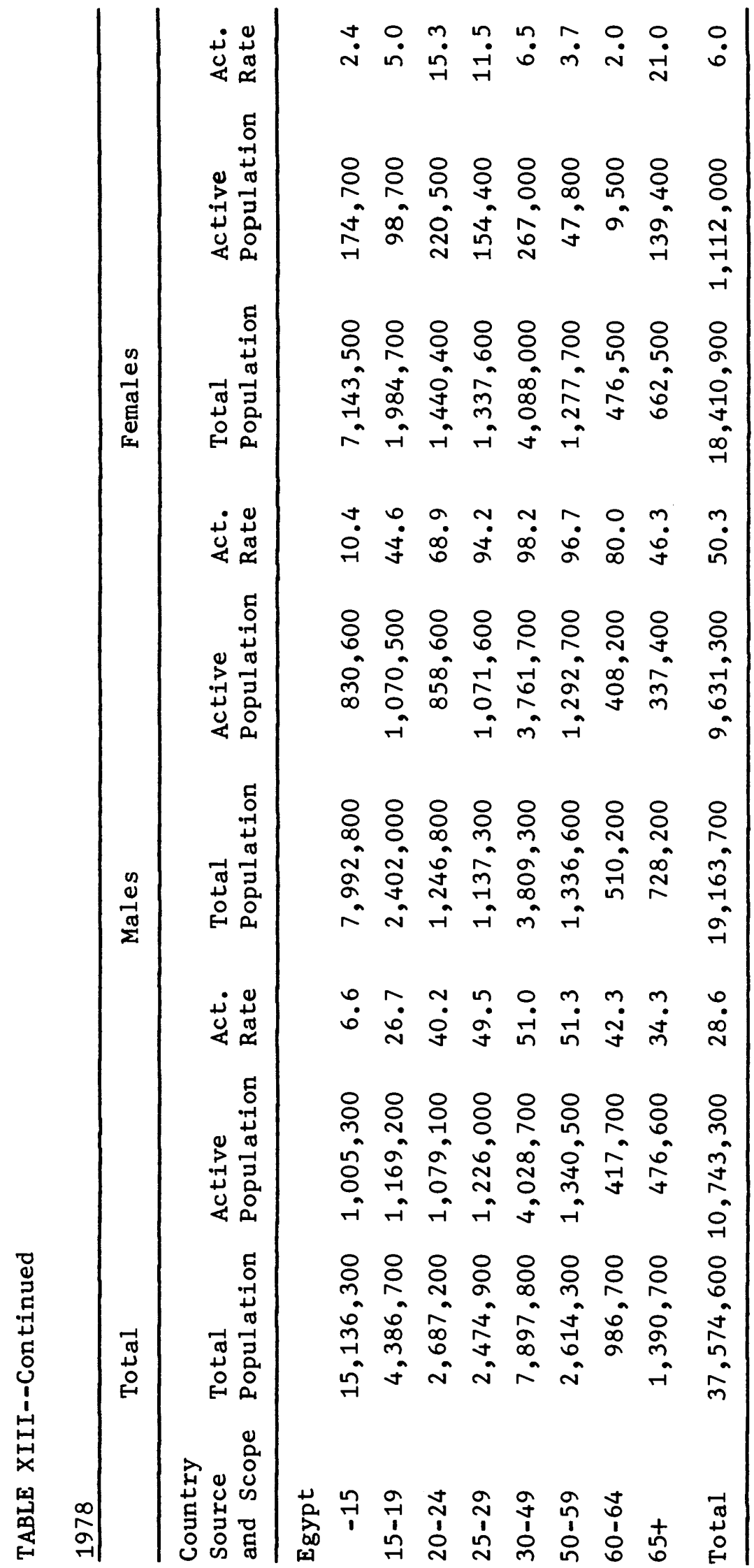




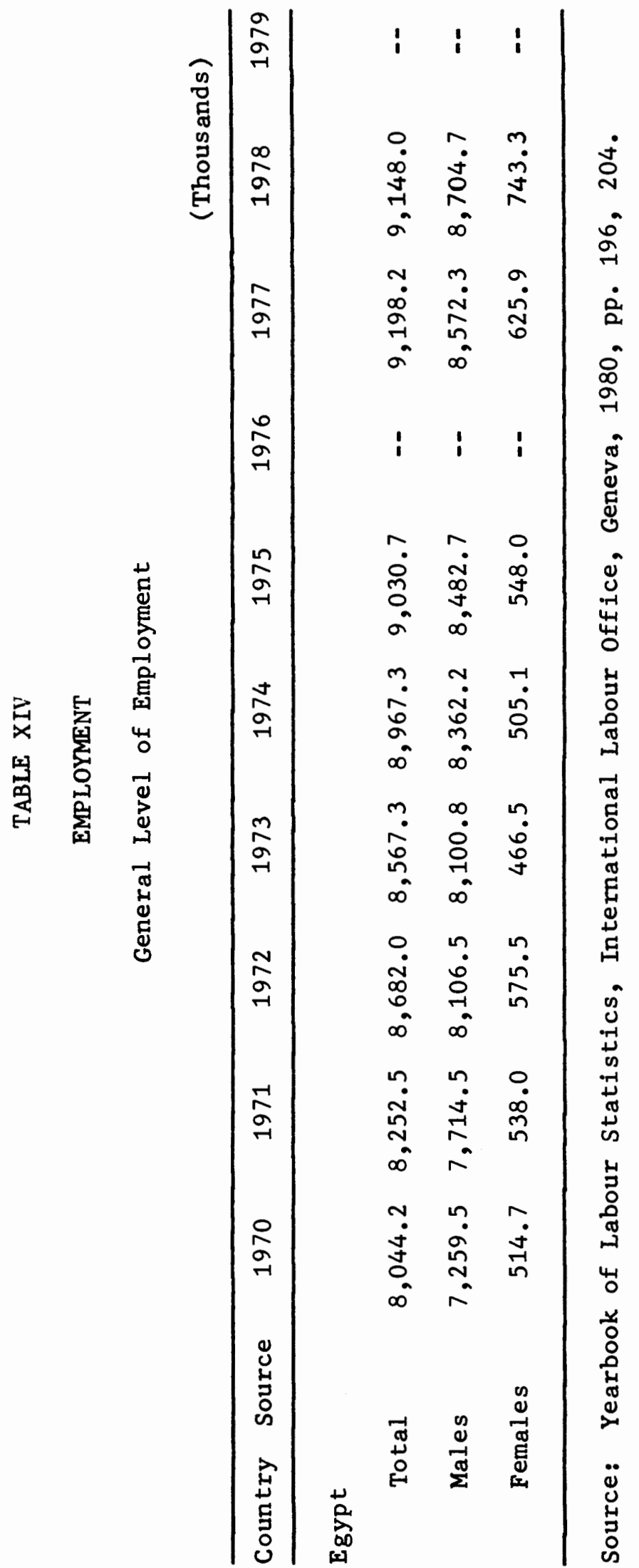




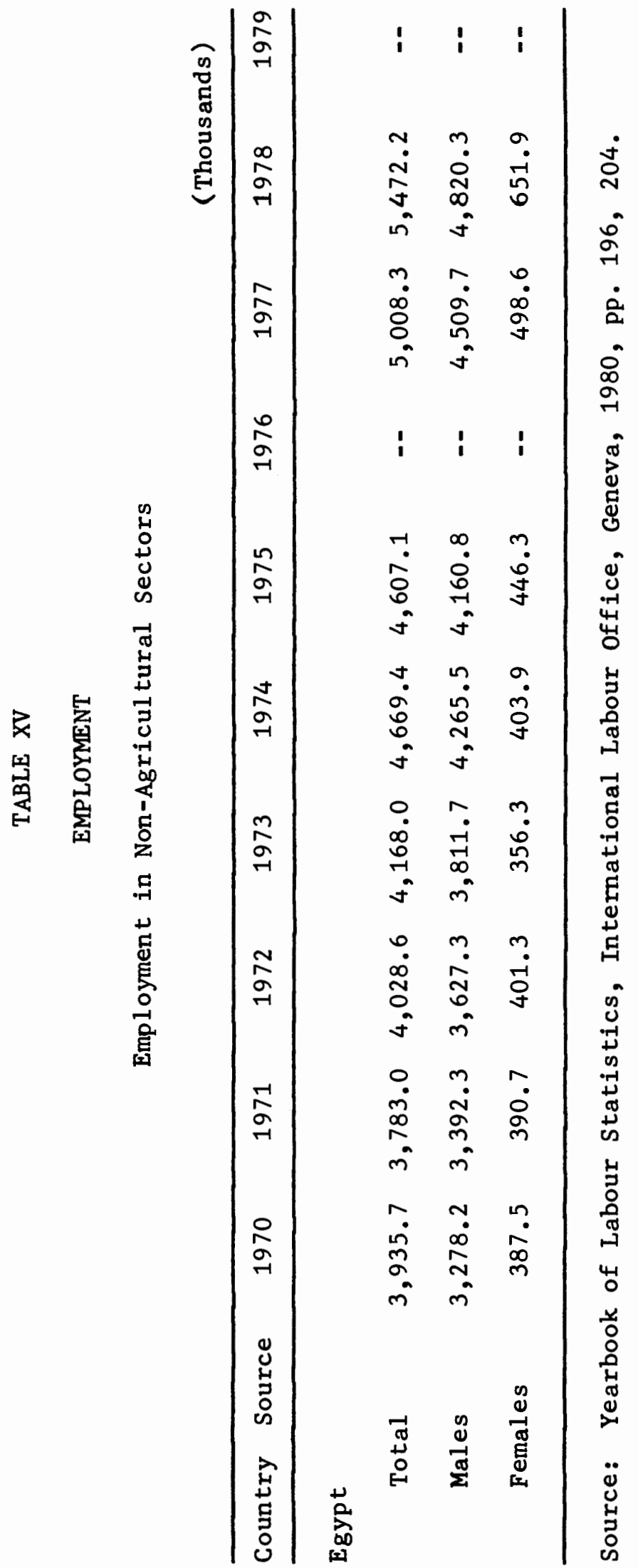




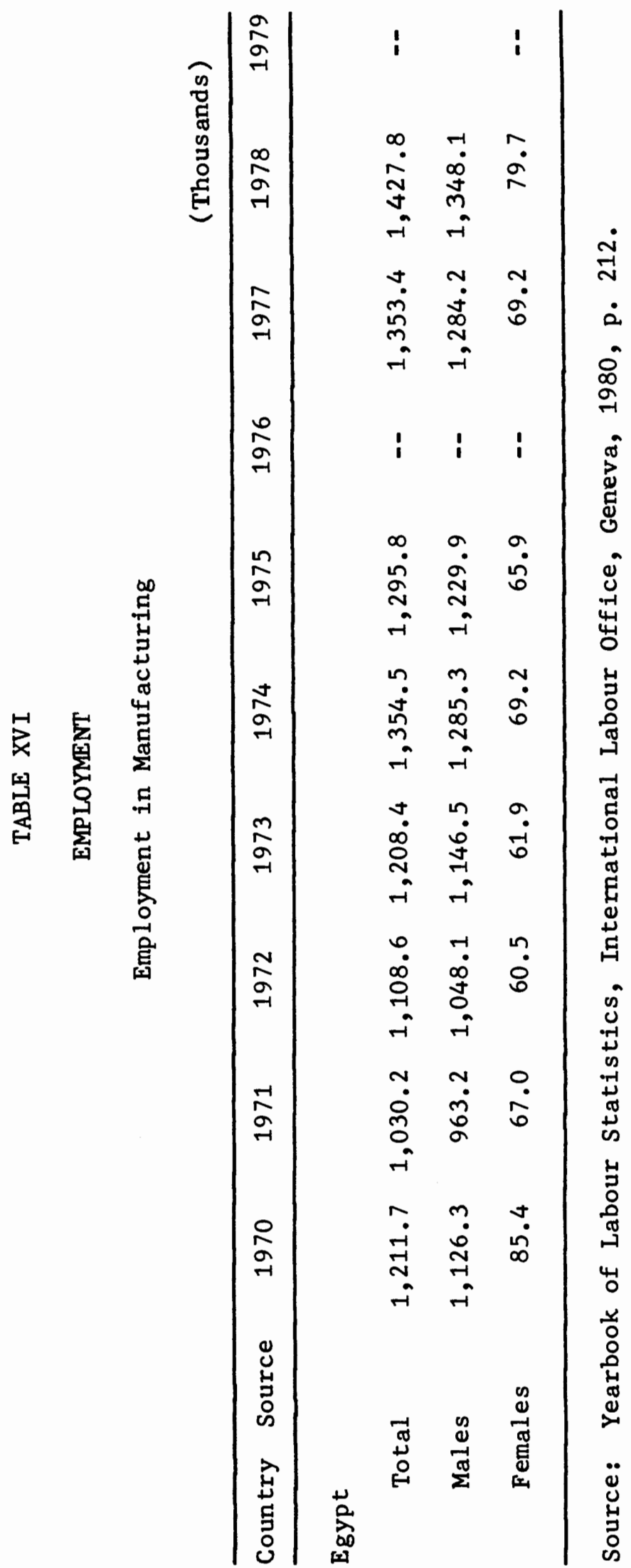


Summary

The following facts have been presented in this study:

1. The dominant religion in M.E. countries is Islam, and the majority of the people are Muslim.

2. Islam brought a lot of respect and support for women to the Arab world, and granted them life, because before Islam the birth of a baby girl was a shame for the father and he of ten buried her alive. But Islam prohibited this and ordered men to respect, love, and support their womenfolk.

3. Since women were not safe and secure in the ancient world, Islam ordered them to be veiled and to cover themselves whenever they were out of the home so as not to be recognized. This Islamic rule in that period of time and in that special place of the world was to protect women from injury and other problems that the men of that time might create for them.

4. According to Islamic rules, seeking knowledge and learning is due everybody, both women and men, but in spite of the Islamic rule, women were prohibited from being educated. There were some enlightened men who educated their daughters in secret. Then some of them appeared in public as a brave and heroic man would and led the country as a queen or became famous as a writer or poet or a scholarly person. These things brought revolutionary ideas to the people. 
5. Women's jobs traditionally for centuries were only domestic tasks, and their world was the home and its work, but when women found a chance and a choice they were brilliant and shone in their society. Moreover, some of them had great activity in creating manual arts, such as rugs, carpets, needlework and embroidery, and woven clothes. Also they participated in farm tasks in many areas.

6. From the end of the eighteenth century there was an industrial revolution that took place in Western countries and changed the lifestyle there. Later this even affected other continents more or less. Women's status changed as well, but this was very slow in M.E. countries. Women's status and their participation in the workforce varied in M.E. countries even among large cities and small towns and villages.

7. At the beginning of the twentieth century, the doors of schools were opened for women and they started to be educated, but at this date there are still millions of women out of schools because of tradition; lack of facilities; shortage of girls' schools, female teachers, and money.

8. New lifestyles needed educated and skilled people and more manpower, so women became educated and participated in the workforce. Their activities range from high positions at the decision-making level to simple employment, working on farms and in factories. If qualified, women could have jobs in most fields that are male dominated. 
9. The percentage of female activities is at a low rate compared to that of activities for men or compared to the rate of female activities on other continents, even considering those countries with a similar development and economic level. The female participation in the workforce varies among M.E. countries; for instance, in Iran, it is 8.9 percent of the active population; in Egypt, 6 percent; and in Yemen, 1 percent.

\section{Obstacles to Change}

There were and still are several factors that are strong obstacles to extension and rapid change and are powerful instruments in reducing the participation rate of women's activities below what they otherwise would be by restricting female involvement in employment sectors which have contact with the opposite sex. These factors are as follows:

1. Tradition that is mixed with the blood of M.E. nations and in some of the countries it even overshadows religion.

2. Religion and conservative ideas among men and women as well.

3. Governmental policy. In fact many of the governments in the M.E. do not want to move rapidly to improve women's status, either from conservatism, male unemployment or a desire not to support and approve changes, especially women's emancipation. Some of them are against westernization.

4. Economic development and 1 ack of revenue sources.

5. Illiterary--its rate is too high in most of the M.E. countries and has caused women to be unaware of their equal rights. 


\section{CHAPTER VI}

\section{CONCLUSION AND PROPOSAL}

Today, nobody can deny that women are human, and since all humans are created equal, it follows that men and women are equal. It is only in the degree of skills, education, knowledge, thought, honesty, and modesty that differences should be noted and allowed to influence our treatment of one another in society. Sex should not play a determining role in equality. From another point of view, men and women are wings of society and these wings have to be strong and equal. In this case society can have a higher flight to progress and success in all countries of the world.

These ideas should be pursued in the M.E. countries as well, because according to Islam and the Koran: "God created humans equal but different." So in the M.E. countries for women's emancipation to be creative and productive, an attempt should be made in several ways in the long term to be fully effective. These ways could be listed as follows:

1. Liberal, wise, and supportive government.

2. Wise governmental policy.

3. Talented and supportive writers and poets to create enlightened articles and poems to awaken people and make them more aware of women's rights.

4. Extended education with sufficient content to make people more intelligent and productive. 
5. Allocation of a certain amount of money for long-term educational programs.

6. One of the most important factors that could change people's ideas toward women's outside jobs is the wise behavior of women who are working now in these countries. They should understand that they have a great responsibility at this period of time; that there is an impact between the changes of lifestyle and tradition; and that they are an example for families in their society. So they should understand their value, be careful in each of their steps to prove their abilities, talent, intelligence, modesty, and fidelity to their family and society and be a good example to persuade the family to accept the changes for their female emancipation. Moreover, these women who are enjoying a liberal life should get valuable things from liberation and use those things to build the road of progress smoother and easier for sisters and the new generation.

Finally, it should be noted that modesty, purity, honesty, fidelity, and morality should be taught to all the people of the country. Today, it is not acceptable that women should be locked up as prisoners at home as the Muslim religious and conservative persons believe--that men could not control themselves if women have outside jobs and work and have contact with them, causing immorality, immodesty, and impurity in society. Both men and women should try to control their behavior and learn to be honest, modest, moral, and truthful to their families and to each other, instead of locking up one sex and giving the other sex all kinds of freedom. 


\section{Footnotes}

1. Hana Umlauf Lane (ed.), The World Almanac and Book of Facts (New York: Newspaper Enterprise Association, Inc., 1982), p. 585 .

2. Ibid., pp. 547-48.

3. Ibid., P. 514 .

4. Ibid., P. 567 .

5. Ibid., p. 352 .

6. World Muslim Gazetteer, 1975, pp. 7, 22, 977-85.

7. U.S. News, December 10, 1979, p. 27.

8. A place located in Saudi Arabia. Kaaba (God's home) is in this city, where all Muslims from all around the world come to visit at the time of pilgrimage if they are able financially and physically.

9. Encyclopedia Britannica, Vol. 12, p. 606.

10. The name of an Arabic month.

11. Encyclopedia Britannica, Vol. 12, p. 609.

12. Charis Waddy, The Muslim Minds (London and New York: Longman Group, Ltd., 1978), p. 14 .

13. Sura, 49, Al-Hogarat (apartments or suites): 13, The Koran (Teheran: Elmi, Publisher, 1390), p. 519.

14. Sura, 2, Baghara (The Camel): 35-37, P. 7; and Sura, 7, Al-Aaraff: 19-24, The Koran (Teheran: Elmi, Publisher, 1390), p. 145.

15. Sura, 9, Al-tobeh (Repentance): 71, The Koran (Teheran: Elmi, Publisher, 1390), p. 178.

16. Sura, 2, Al-Baghara (The Cow): 233, The Koran (Teheran: Elmi, Publisher, 1390), p. 34; Sura, 7, Al-Aaraff: 31, The Koran

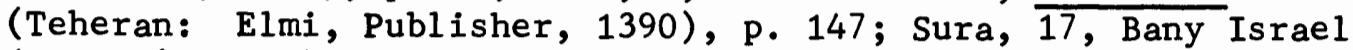
(Israel's Sons): 29, The Koran (Teheran: Elmi, Publisher, 1390), p. 276; Sura, 65, Al-Tallagh (Divorce): 5-7, The Koran (Teheran: Elmi, Publisher, 1390), p. 564 . 
17. Sura, 2, Al-Baghara (The Cow): 229-32, The Koran (Teheran: Elmi, Publisher, 1390), p. 34; and Sura, 4, Al-Nessa (Women): 129, The Koran (Teheran: Elmi, Publisher, 1390), p. 92.

18. Sura, 4, Al-Nessa (Women): 34, The Koran (Teheran: Elmi, Publisher, 1390), p. 77.

19. Sura, 24, Al-Nour (Light): 26-27, The Koran (Teheran: Elmi, Publisher, 1390), p. 346.

20. Ibid., 29-30, p. 346 .

21. Ibid., 31, p. 347 .

22. Sura, 33, Al-Ahzab ( $C l$ ans): 35, The Koran (Teheran: Elmi, Publisher, 1390), p. 419.

23. Ibid., 33, p. 419.

24. Ibid., p. 423 .

25. Funk \& Wagnalls New Encyclopedia, Vol. 13, 1973, pp. 286-87. The Industrial Revolution started from Great Britain in 1760 .

26. Now is the capital of Iran.

27. E. E. Fered and B. Q. Bezirgan, Middle Eastern Women Speak (University of Texas, 1977), pp. 3-6; R. A. Nicholson, Literary History of the Arabs (Cambridge, 1930), p. 166.

28. Gholamreza Ensafpour, Women's Power and Status in History (Teheran, Iran: Kanone Ketab Company, 1967), pp. 233-35. ( Tr. from the Persian by the researcher.)

29. Ibid., pp. 236-37.

30. Ibid., pp. 248-50.

31. Ibid., pp. 232-33.

32. A part of Iran.

33. Gholamreza Ensafpour, Women's Power and Status in History (Teheran, Iran: Kanone Ketab Company, 1967), p. 243.

34. Charis Waddy, Women in Muslim History (London and New York: Longman Group, Ltd., 1980), pp. 12-13.

35. Gholamreza Ensafpour, Women's Power and Status in History (Teheran, Iran: Kanone Ketab Company, 1967), pp. 62-63; Charis Waddy, Women in Muslim History (London and New York: Longman Group, Ltd., $\overline{1980}$ ), pp. 43-45. 
36. Ibid., pp. 43-45; Gholamreza Ensafpour, Women's Power and Status in History (Teheran, Iran: Kanone Ketab Company, 1967), pp. 163-64.

37. Gholamreza Ensafpour, Women's Power and Status in History (Teheran, Iran: Kanone Ketab Company, 1967), pp. 124-26.

38. Ibid., pp. 128-29.

39. Ibid., pp. 129-30.

40. Ibid., pp. 156-66.

41. Ibid., pp. 166-67.

42. Ibid., pp. 130-31.

43. Ibid., pp. 124-26.

44. Charis Waddy, Women in Muslim History (London and New York: Longman Group, Ltd., 1980), pp. 88-89.

45. Information Please, Almanac Atlas \& Yearbook (New York: Simon and Schuster, 1981), p. 194.

46. Samira Harfoush and Kathy Sullivan, "Women and Higher Education in the Arab World"' (Washington, D.C., 1980), pp. 15-21.

47. Ibid., pp. 13-14.

48. Ibid., p. 15 .

49. Ibid., p. 16 .

50. "World Development Report," The World Bank (Washington, D.C., 1979), pp. 170-71.

51. Badr Al-Muluk Bamdad, From Darkness Into the Light: Women's Emancipation in Iran (New York: Exposition Press, 1977), pp. 95-98.

52. Behnaz Pakizegy, Women in the Muslim World (Cambridge, Mass.: Harvard University Press, 1978), pp. 216-17.

53. "Statistics of Higher Education in Iran," 1974, pp. 34-39.

54. Behnaz Pakizegy, Women in the Muslim World (Cambridge, Mass.: Harvard University Press, 1978), pp. 216-19.

55. Ruth Frace Woodsmal1, Women and the New East (Washington, D.C.: Middle East Institution, 1960), pp. 84-85.

56. World Survey of Education: Secondary Education (New York: International Documents Service, 1961), pp. 680-81. 
57. World Survey of Education: Primary Education (Paris, UNESCO, 1958), Vol. II, pp. 557-66.

58. World Survey of Education (New York: United Nations Educational Scientific, 1958), Vol. II, p. 625; and Vol. V, UNESCO (Paris, 1971), pp. 614-15.

59. Safia K. Mohsen, The Egyptian Women: Between Modernity and Tradition, Maghiassea, Foel Press, 1977, pp. 44-46.

60. World Survey of Education: Primary Education (Paris, UNESC0, 1958), Vol. II, Pp. 335-44.

61. Nadia H. Youssef, "Demography," Social Structure and the Female Labor Force, Vol. 8, No. 4, November 1971, p. 430 .

62. Ibid., pp. 428-31.

63. Ibid., p. 433.

64. Ibid., pp. 434-35.

65. Hana Umlauf Lane (ed.), The World Almanac and Book of Facts (New York, 1982), p. 585 .

66. "Yearbook of Labour Statistics" (Geneva: International Labour Office, 1980), p. 23.

67. Ibid., 1979, p. 52 .

68. Morteza Mottahari, Women's Rights in Islam (Teheran, Iran: Islamic Cultural Publishing office, 1974), pp. 99-177.

69. "Yearbook of Labour Statistics" (Geneva: International Labour Office, 1980), pp. 196, 204.

70. Ibid., p. 212 . 
Abdal-ati, Hammudah. "Modern Problems Classical Solutions: An Islamic Perspective on the Family." Journal of Comparative Family Studies. Vol. V, No. II, $197 \overline{4 .}$

Afsharnia, Alireza. Women's Deliverance from the Product Power. Teheran: Pioneer Publications, 1977/1357.

Alahi Gomshei, Mehdi. Holy Qur'an. Teheran: Elmi, Publisher, 1976/ 1356.

Al-Qazzaz, Ayad. "Women in the Middle East and North Africa." Middle East Monograph. Number 2. Austin, Texas: Center for Middle Eastern Studies, University of Texas, 1977.

Altorki, Soraya. "Family Organization and Women's Power in Urban Saudi Arabian Society." Journal of Anthropological Research, 1977.

Arberry, Arthur. The Koran Interpreted. Paperback. New York: Macmillan, 1964.

Bamdad, Badr al-Muluk. From Darkness Into Light. Translated by: F.R.C. Bagley. New York: Hicksville, Exposition Press, 1977/ 1357 .

Beck, Lois and Keddie, Nikki R. Women in the Muslim World. Cambridge, Mass. \& London: Harvard University Press and Cambridge University Press, 1978.

Bell, Richard. Introduction to the Koran. Rev. New York: Aldine, 1958.

Bezirgan, Ferned B.Q. Middle Eastern Muslim Women Speak. Austin: University of Texas Press, 1977.

Buvinic, Mayra. "Women and World Development: An Annotated Bibliography." Washington, D.C.: Overseas Development Council, 1976.

Cohen, Mark I. and Halm, Lorna. Morocco: Old Land, New Nation. New York: Frederick A. Praeger, 1966-69.

Darabi, Katherine F. "Education and Fertility in Iran." Demographic Overview Journal. Volume II, Number 2, 1976.

Dawood, N. J. The Koran. Paperback. London: Penguin, n.d. 
Dodd, Peter C. "The Effect of Religious Affiliation on Woman's Role in Middle Eastern Arab Society." Presentation of the Eighth World Congress of Sociology, Session on Sex Role and Society. Toronto, 1974. Journal of Comparative Family Studies. Vol. V, Number 2, Autumn 1974.

Dodd, Peter C. "Youth and Women's Emancipation in the United Arab Republic." The Middle East Journal. Vol. V, Number 2, 1974.

"Education in Jordan in Figures." Amman. Jordanian Ministry of Education, 1978-79.

Ensafpour, Golamreza. Women's Power and Status in History. Teheran, Iran: Kanone Ketah Company, 1967/1346.

"Family Planning - Tunisia." American University Field Staff Reports. North African Series, Volume XIII, No. 2.

Fischer, Michael, M.J. Iran from Religious Dispute to Revolution. Cambridge, Mass. \& London: Harvard University Press, 1980.

Gordon, David C. Women of Algeria: An Essay on Change. Center for Middle Eastern Studies of Harvard University. Cambridge, Mass.: Harvard University Press, 1968.

Harfoush, Samira and Sullivan, Kathy. "Women and Higher Education in the Arab World." World Higher Education, Vol. 2, No. 3, 1980.

Hooks, Janet. "Women's Occupation Through Seven Decades." Women's Bureau. Bulletin No. 218, 1947.

Hussein, Aziza. "The Role of Women in Social Reform in Egypt." The Middle East Journal. Princeton, N.J. 1953.

Keddie, Nikki R. "Problems in the Study of Middle Eastern Women." International Journal of Middle East Studies. 10, 1979. Suggestions about methodology for the study of women in both historical and contemporary perspectives.

Maher, Vanessa. Women and Property in Morocco. London: Cambridge University Press, 1971.

"Middle East." American Middle East Education and Training Services. Washington, D.C., 1981.

Mohsen, Sofia K. "The Egyptian Woman Between Modernity and Tradition." Foec Press, 1974.

Momeni, Djamshid. "Polygyny in Iran." Journal of Marriage and the Family. Shiraz, Iran: Pahlavi University, 1975. 
Moore, Henry Clement. Politics in North Africa. Boston: Little, Brown \& Co., 1970.

Mottahari, Morteza. Women's Rights in Islam. Teheran, Iran: Ziba Farsi, Publisher, 1974/1353.

Negare-Zan. International Women's Club of Iran. Teheran, 1973.

Nelson, Cynthia. Public and Private Politics: Women in the Middle Eastern World. Cairo: American University, Cairo, 1977.

Pakizegi, Behnaz. Women in the Muslim World. Cambridge, Mass.: Harvard University Press, 1978.

Paydarfar, Alia. "The Modernization Process and Household Size, A Provincial Comparison for Iran." University of North Carolina, Journal of Marriage and The Family. May 1975.

"Persian Year Book." Ministry of Interior Press, 1974/1353.

Rasekh, Mehri. "Psychological Characteristics of Iranian Women." In The Role of Women in the Culture and Civilization of Iran (in Persian). Teheran, 1971.

Rasekh, Shapour. "The Influence of Economic and Industrial Development on the Change in the Form of Duties of the Iranian Family." In Family and Culture (in Persian). Teheran, 1974.

Shafik, Doria. "Egyptian Feminism." Middle Eastern Affair. 1952.

Saleh, Saheya. "Women in Islam: Their Status in Religious and Traditional Culture." International Journal of the Sociology of the Family. 2, No. 1, 1972.

Smock, Audrey Chapman and Youssef, Nadia Haggog. "Egypt: From Seclusion to Limited Participation." Women: Roles and Status in Eight Countries. Ed. by Janet Zollinger Giele and Audrey Chapman Smock. New York: John Wiley \& Sons, 1977.

Touba, Jacquiline Rudolph. "Sex Role Differentiation in Iranian Families Living in Urban and Rural Areas of a Region Undergoing Planned Industrialization in Iran." (Arak Shahrestan) University of Tehran. Journal of Marriage and The Family. May 1975.

Waddy, Charis. The Muslim Mind. London and New York: Longman, 1976.

Waddy, Charis. Women in Muslim History. London and New York: Longman, 1980 . 
Wakeman, Katherine Kendal1. Personality Development in an Iranian Village: An Analysis of Socialization Practices and the Development of the Women's Role. (Thesis) University of Washington, 1968.

Wilber, Donald N. Iran: Past and Present. Princeton, N.J.: Eighth Edition, 1976.

Woodsmall, Ruth. "Study of the Role of Women: Their Activities and Organizations in Lebanon, Egypt, Iraq, Jordan and Syria." New York: International Federation of Business and Professional Women, 1955.

Woodsmal1, Ruth Frances. Women and the New East. Washington, D.C.: The Middle East Institute, 1960.

"World Higher Education Communique." Institute of International Education, 1980 .

World Survey of Education, II, Primary Education, UNESCO, Paris, 1958.

World Survey of Education, IV, Higher Education, UNESCO, New York, 1980.

World Survey of Education, V, UNESCO, Paris, 1971.

Yearbook of Labour Statistics, International Labour Office, Geneva, 1977.

Youssef, Nadia. "Social Structure and the Female Labor Force: The Case of Women's Work in Muslim Middle Eastern Countries." Demography. California: California state College, Institute of International Study, Vol. 8, No. 4, 1971.

Youssef, Nadia and Merrian, Kathleen Howard. "Women's Education and Profession in Egypt." Comparative Education Review. Chicago: University of Chicago Press, XXIII, No. 3, 1979. 
$\begin{array}{lllllllll}\text { A } & P & P & E & N & D & I & X\end{array}$ 


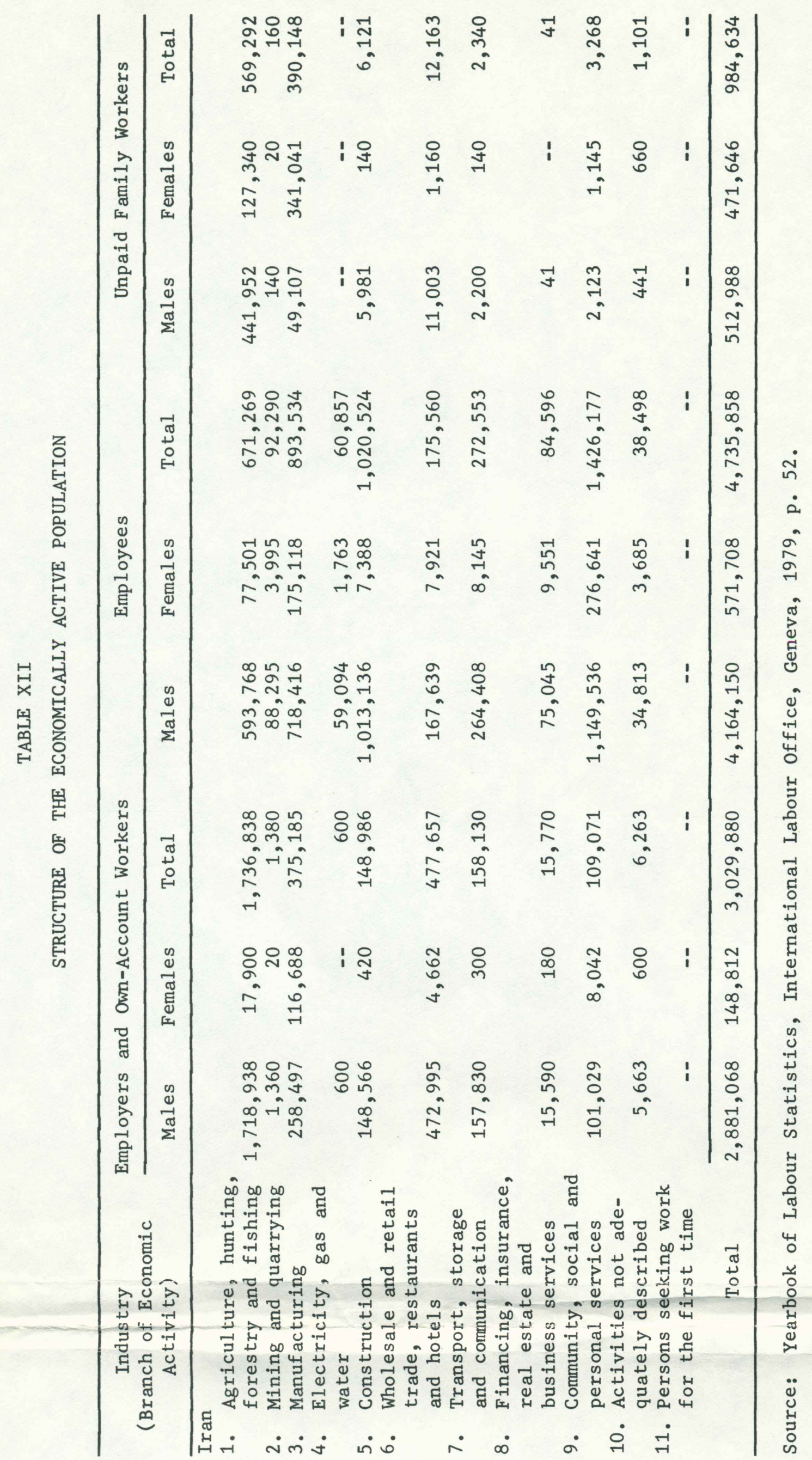




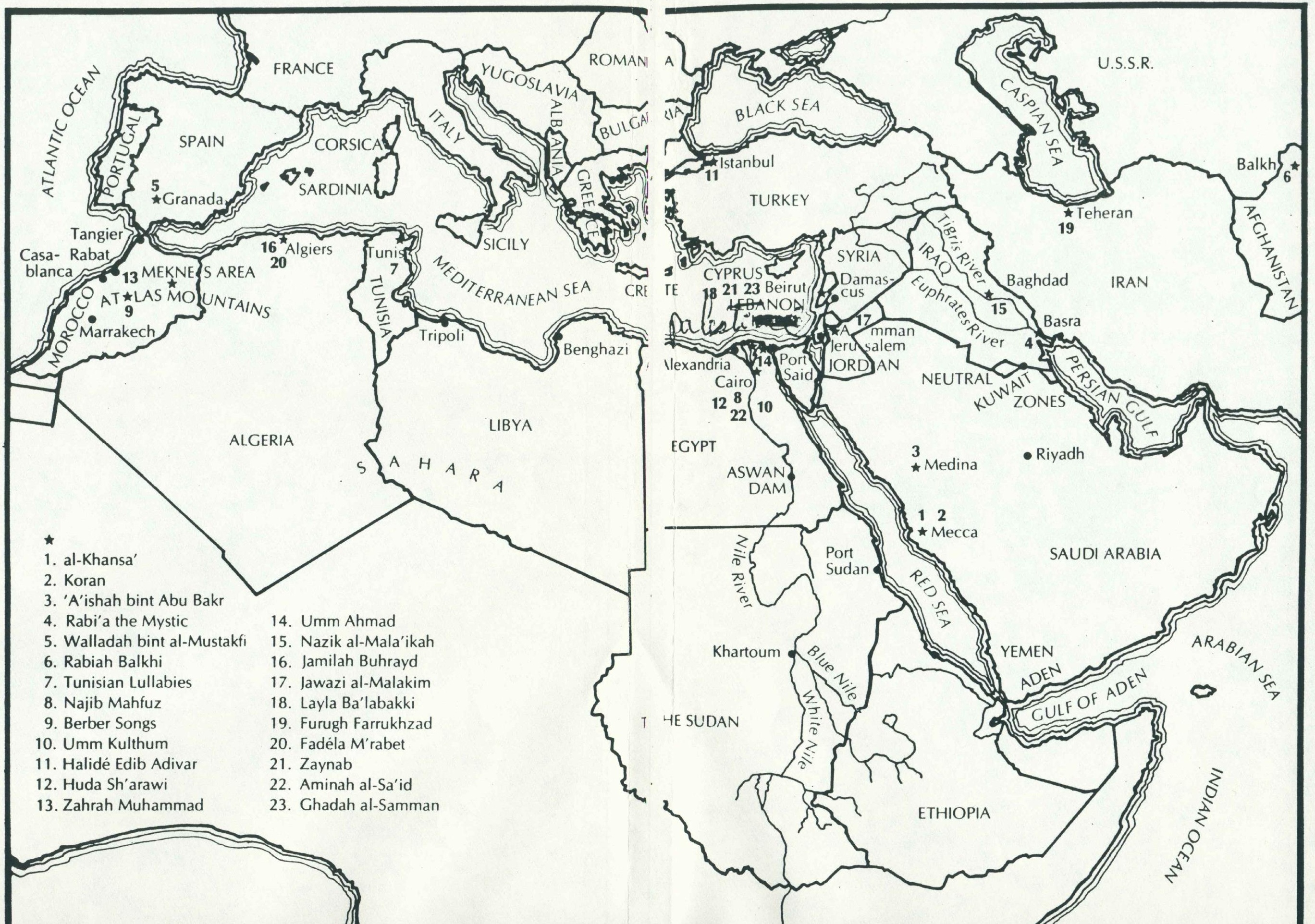


WOMEN'S COSTUMES IN DIFFERENT LOCATIONS AND DIFFERENT TIMES IN IRAN 
Lnek

ADOR

$-1900 \%$ cy $1=0$

$T=:$

khch:?

1

- Cin int see moner)

This chador Folay

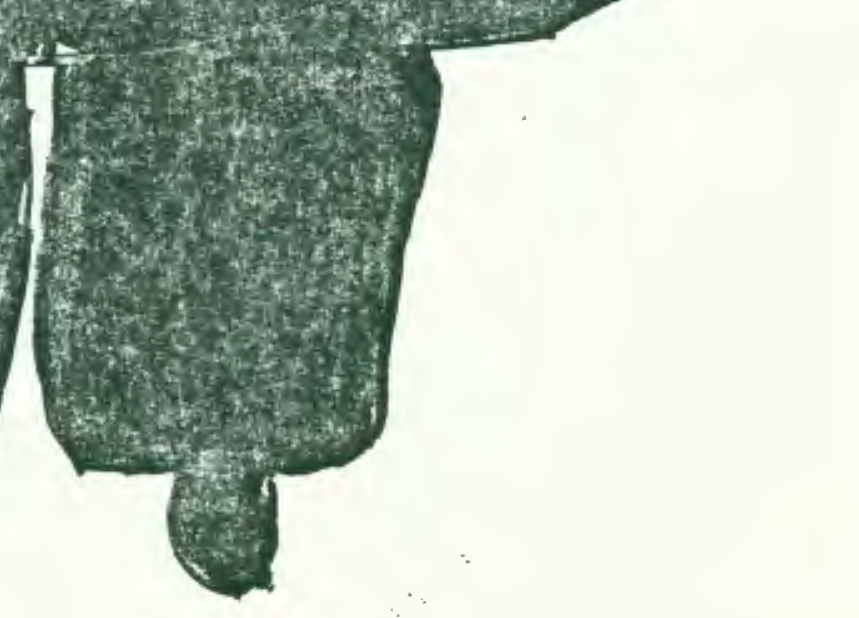




\section{$y x 1 L$}

PRay.'S Chadori re ore ilat of prophe

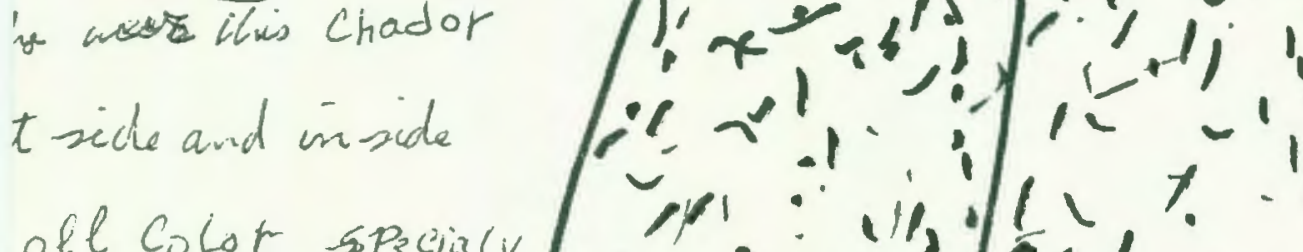
t siche and inside
oll Color specialy
Lack

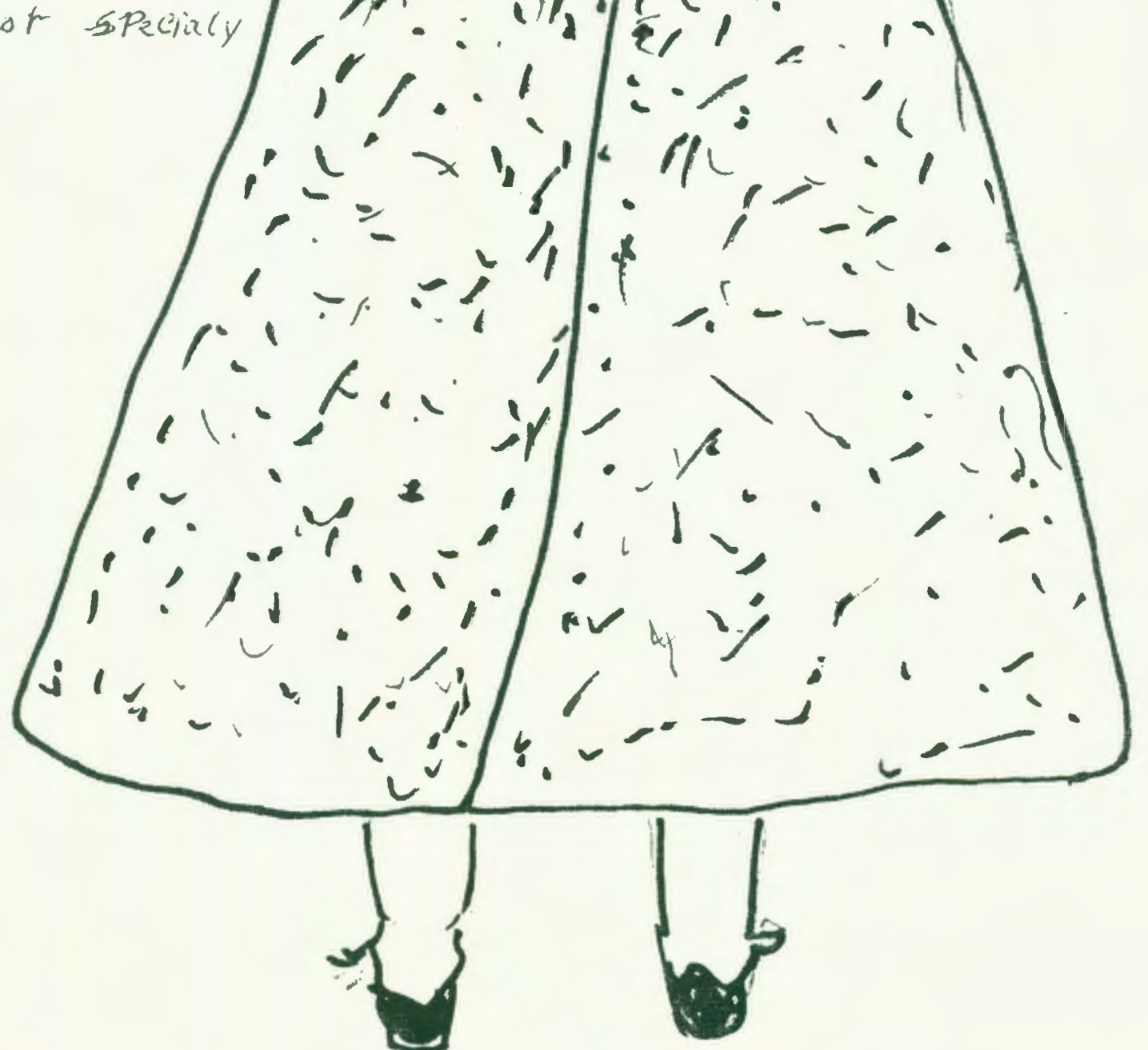




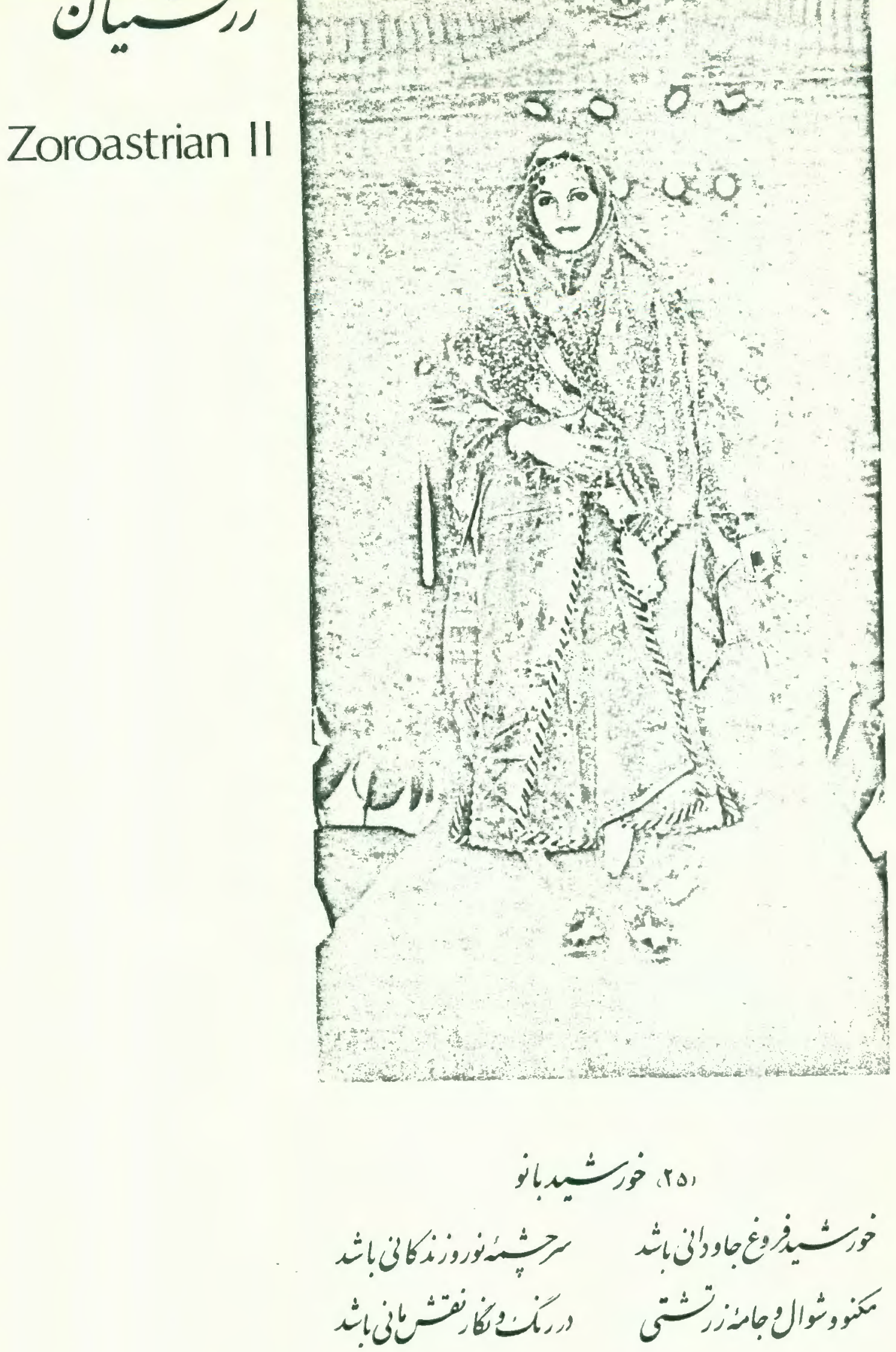

25. Khorshid Banou 


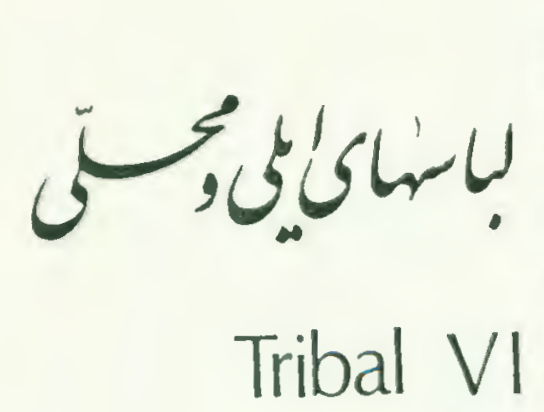

W w w y

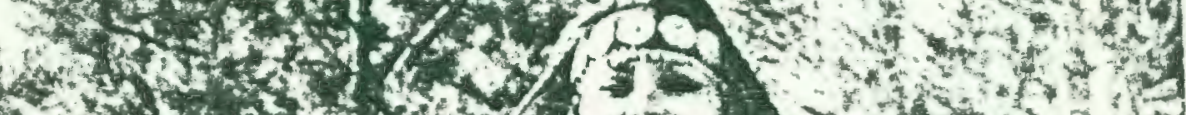

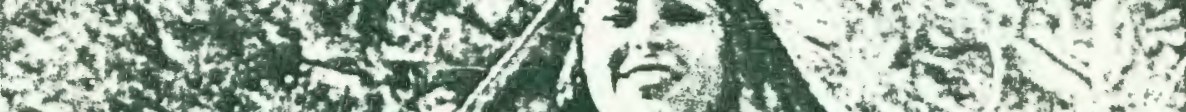

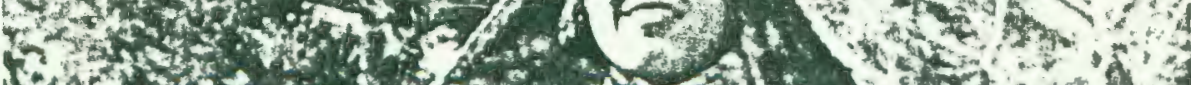

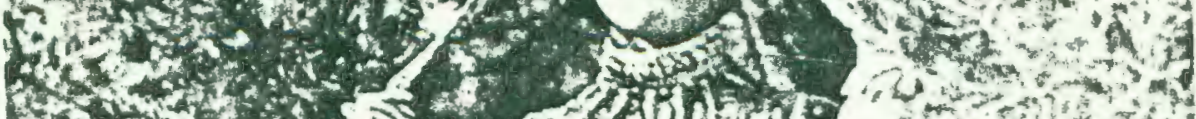

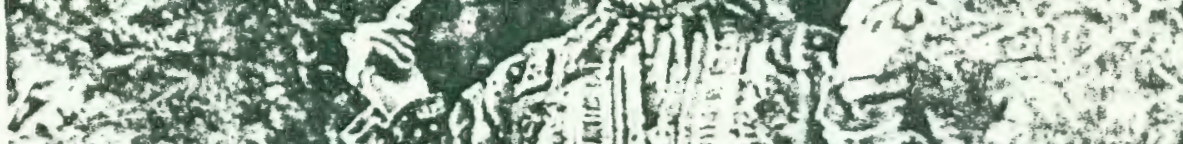
-

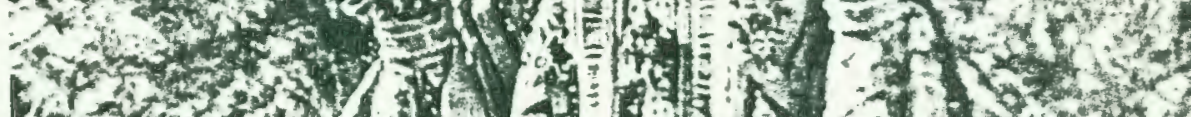

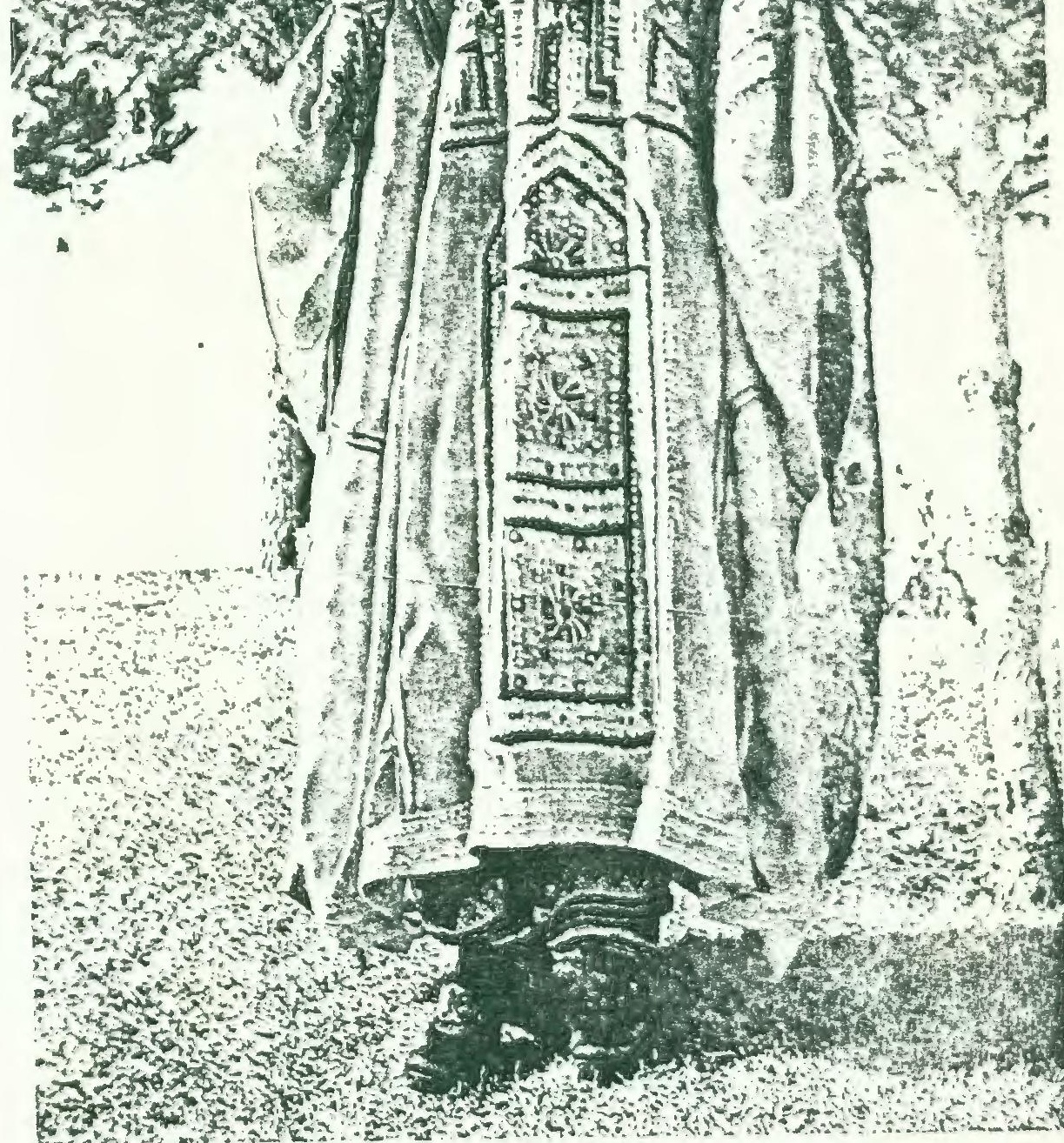

Cors

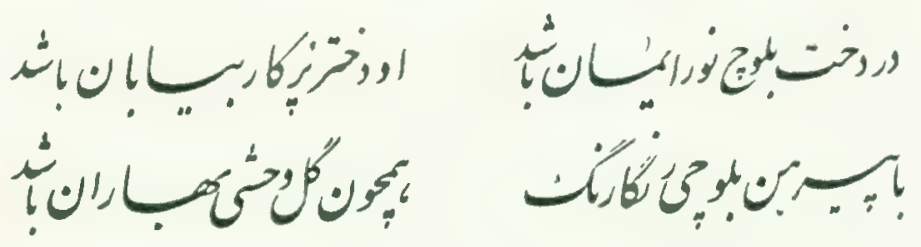



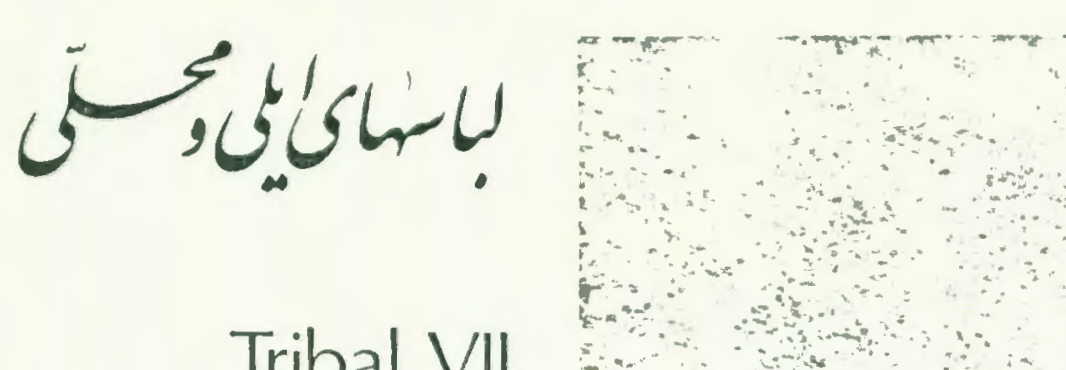

Tribal VII
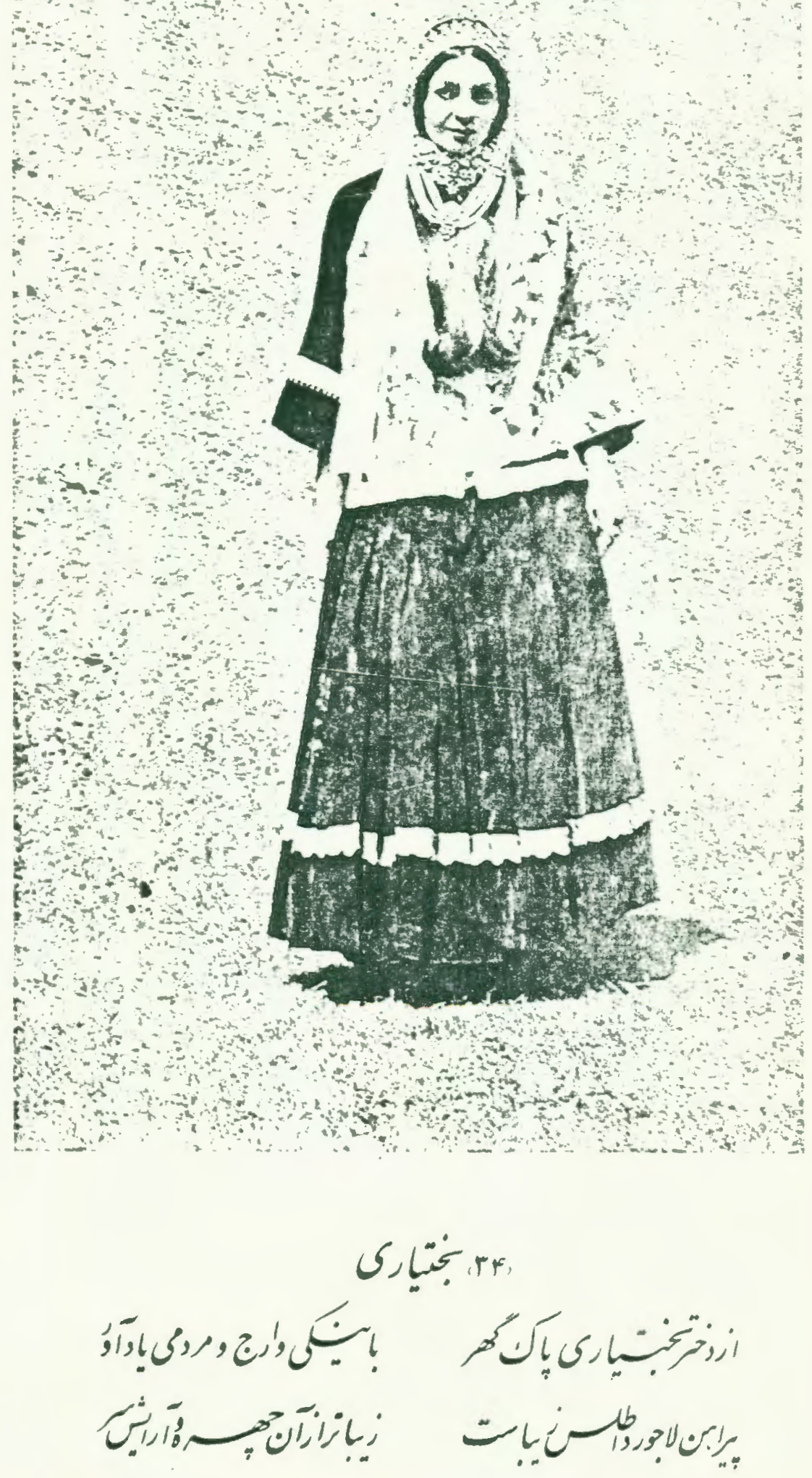


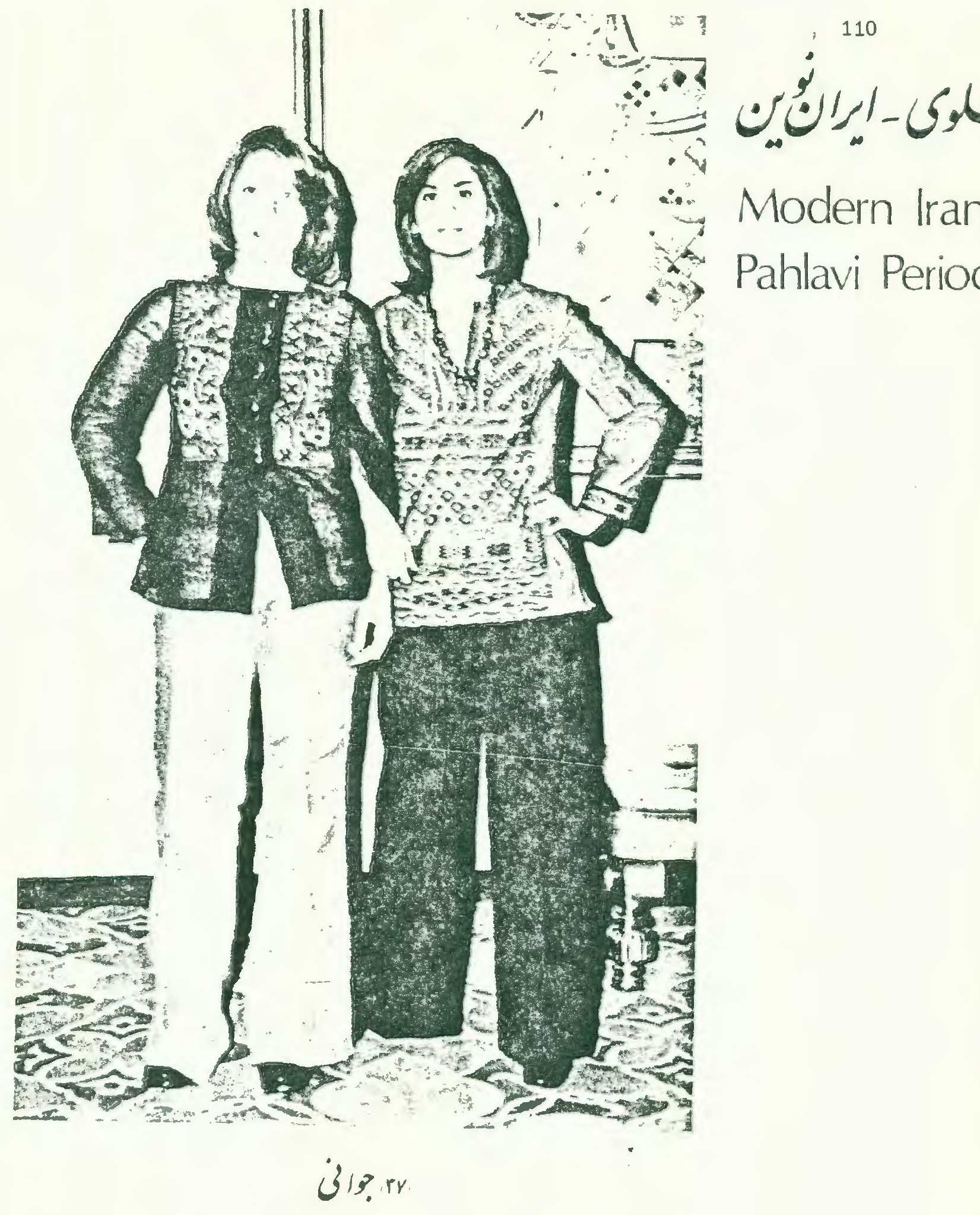

إنتّنُ

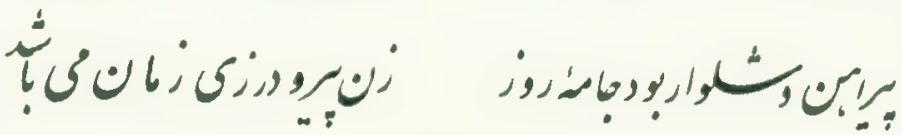


Is it a dunge or a rocket aw The first sight on arriving somewhat $p$ that of a natio strate its origi The white erected at the tal city (See ti master door in It is colossal wind-filled iil promise of th as history's $\mathrm{m}$ anchored to t wards in an a? massive, simp tral body. Th audacious. T? inspired by ishingly "mo might well ha feature which first glance: th the whole dyn is suddenly in the sky-line a: tarily been ca day... Present be confirmed seems that on the Shahyad rated, the mes solid, the imp tion is heading tiny... The higher!

This is a long most mediaeva Montesquieu Even in 1910 to the Caspia expedition wh Claude Anet, med accom guards. 1910 , Now the mod for himself Tower is no Planes, trains to the most

Costumes vary from the raditional "chador" to beach-wear on the Caspian Sea. but the friendly smile is the same everywhere... 
WOMEN IN DIFFERENT POSITIONS IN IRAN 


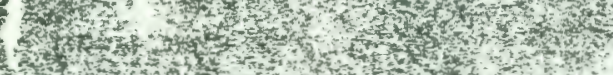

(n)

thents

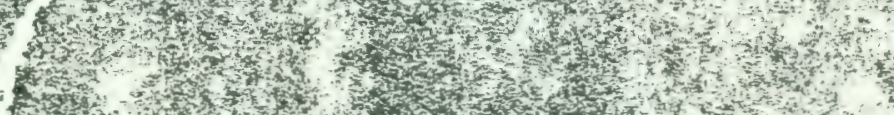
r

F,

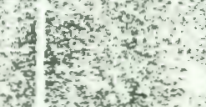

if
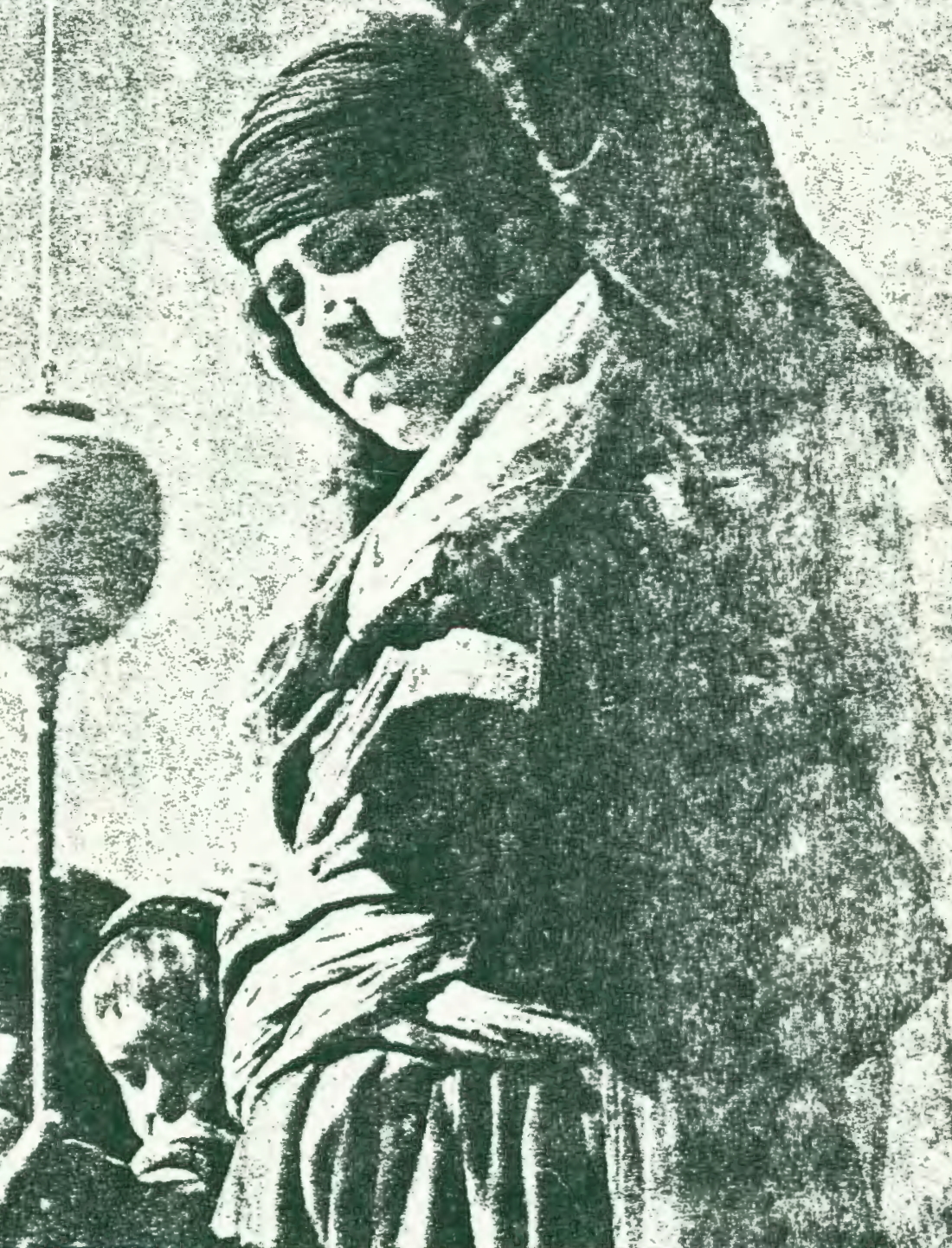

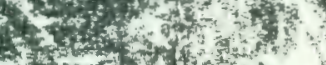

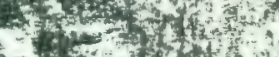
$y+y^{2}+x^{2}+1$
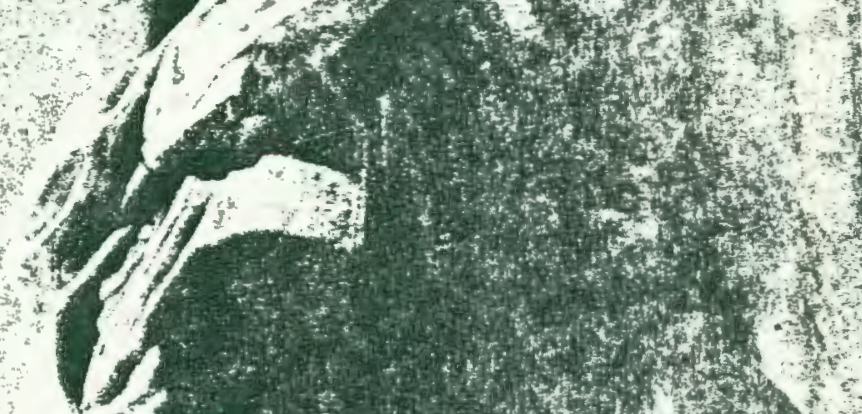


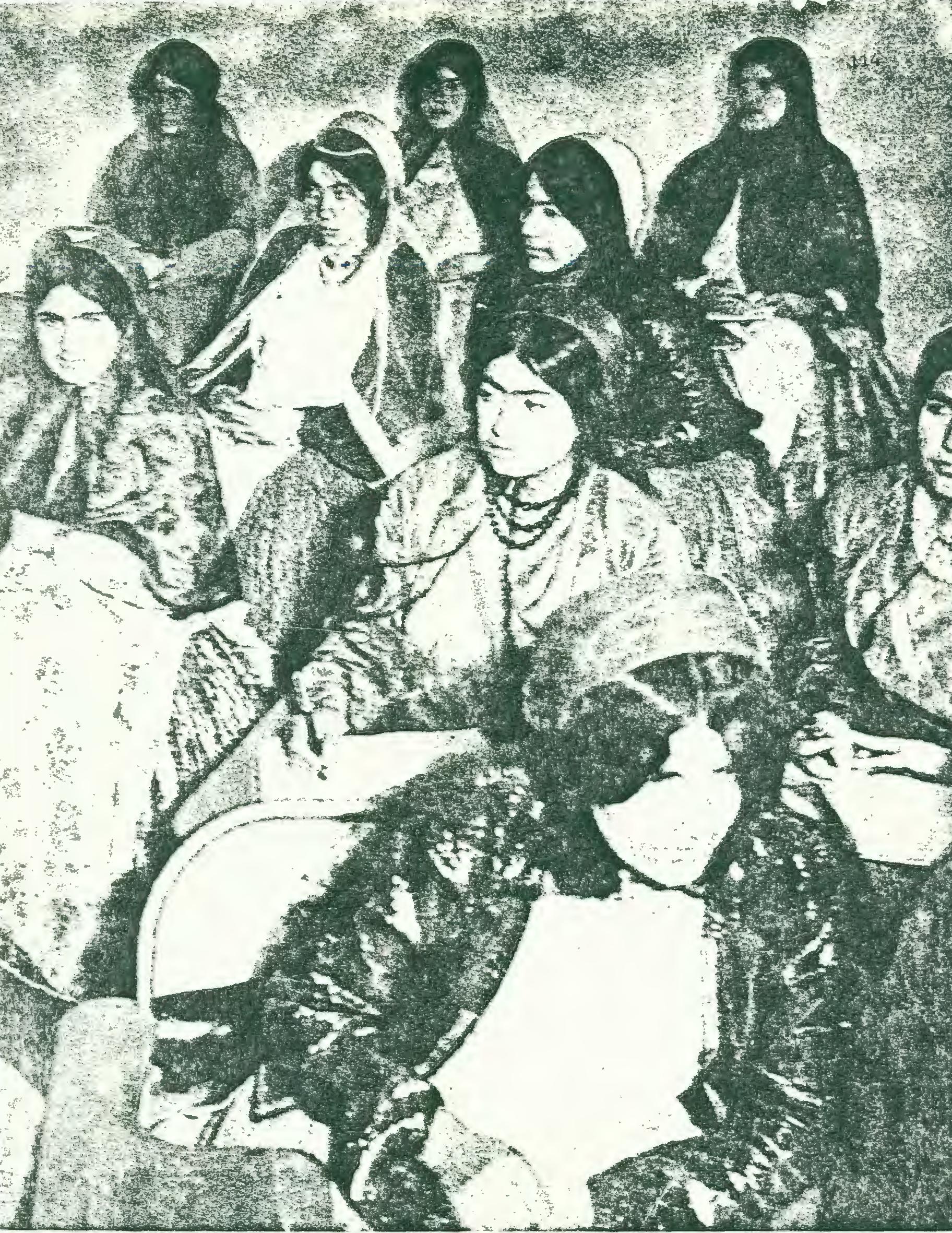

The problem of educating children in tribal areas has been solved by establishing nomadic schools which migrate with the tribes. These trainee teachers are undergoing instruction in the Tribal Teachers Training School in Shiraz. 


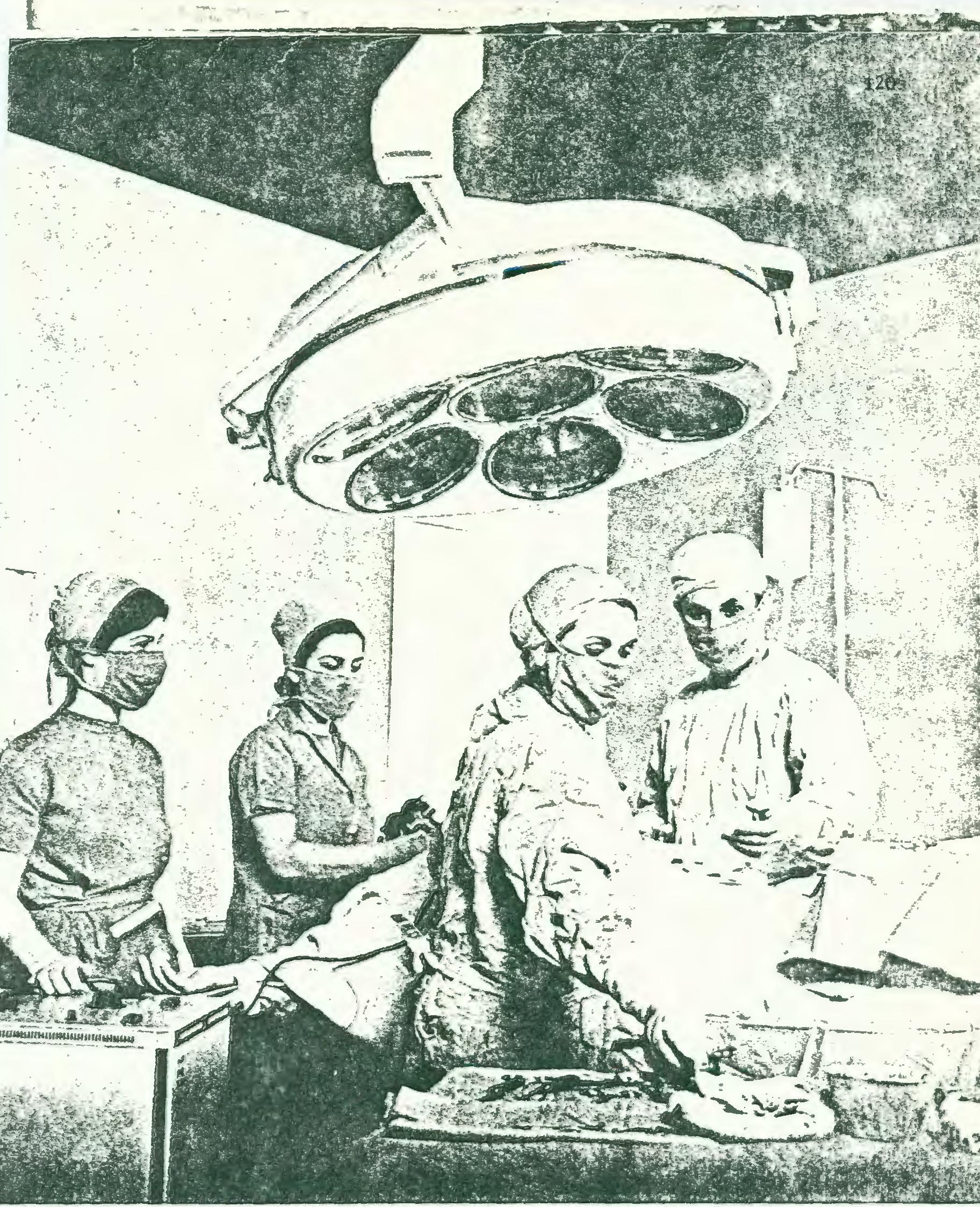

Operating theatre in a modern Tehran hospital 
of every | statistics reflected in 1970 an alnument, most general increase in agricul$t$ in the tural production.

ecorated by garorations. angraved ig length poem... its of the rought to s-by and edge.

of prime slopment. se notice nt whole tive value mentation. ady been ase, they hemselves, era.

ceived the d drafting laimed the ved by an e Iranian 1963. Its immedi-

revolution grarian reilies benewhich in of land to it. Landted by a imes their $d$ in their sants must the land vears. This the farmer one-third maintained ction after it of fact,

Several other principles laid down by the White Revolution directly complement the agrarian reform. Point 2, for example, made possible the conservation of forests and pastures. Severe regulations govern tree-felling. A large corps of forestry guards was formed and is proceeding in many areas (such as the plain north of Shiraz around a modern agronomic school which the tourist can observe from the road). The dambuilding programme and numerous irrigation projects are an offshoot of "point 10" on the nationalization of water.

\section{Educution Corps}

The traveller may notice smali badge-shaped blue signs along the roads were they intersect with tracks, indicating an isolated and remote village in which has been set up one of the three thousand schools built in 1971 with a teacher belonging to the "Education Corps".

This name symbolizes a very simple but really revolutionary idea. A portion of the contingent of conscripts is now used on nonmilitary tasks to implement the peaceful principles of the White Revolution and to contribute to the country's development.

Each year, several thousand young conscripts, instead of being sent to military barracks, go to remote villages as teachers (Education Corps), as sanitation or medical advisers (Health Corps), or as agronomic technicians (Development Corps). There are even since recently, about fifty students in theology which make up a small "Religion Corps", itinerant commentators of Shi'ism.

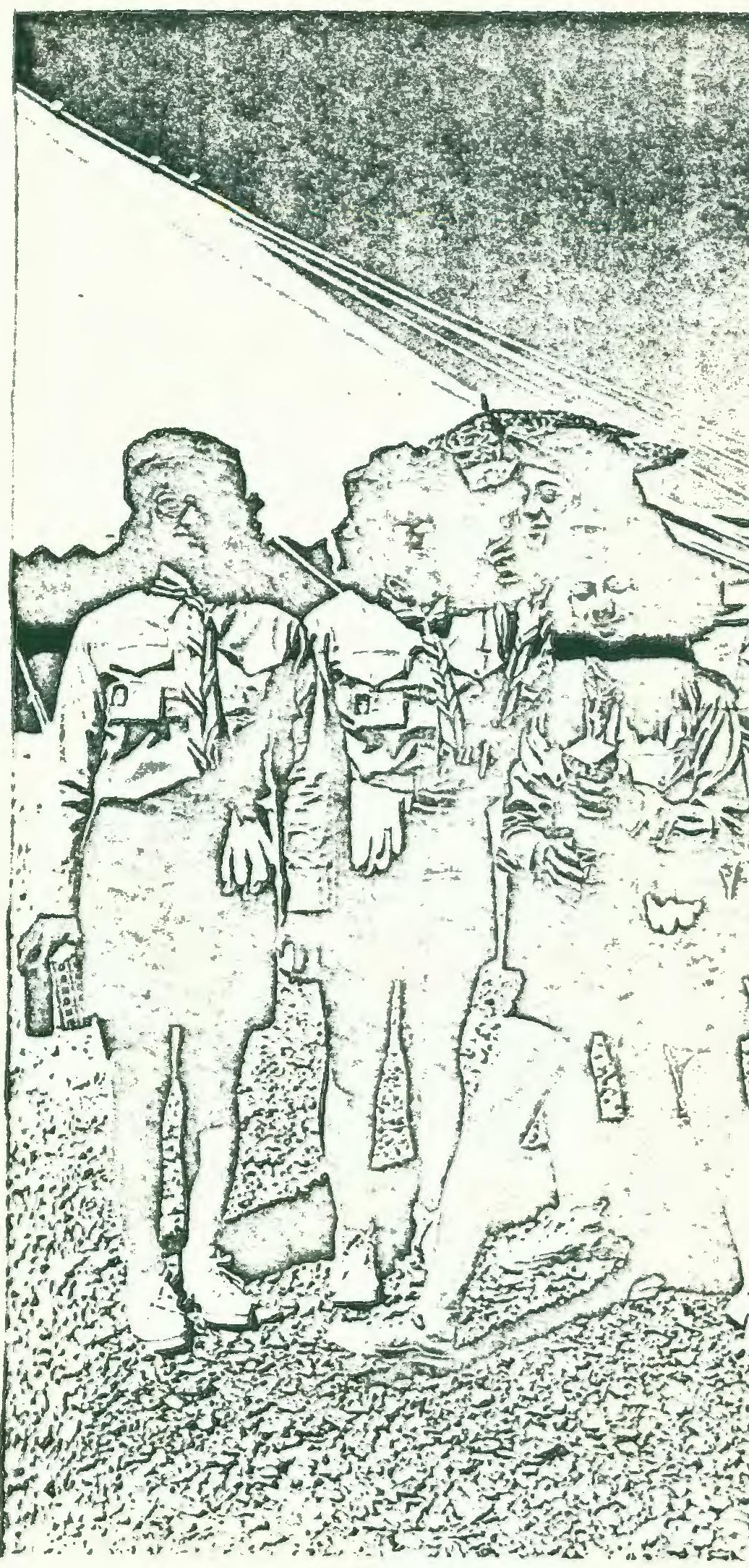

W'omen's emancipation

is a reality in modern Iran,

as shown by these young "scout-girls" who, 


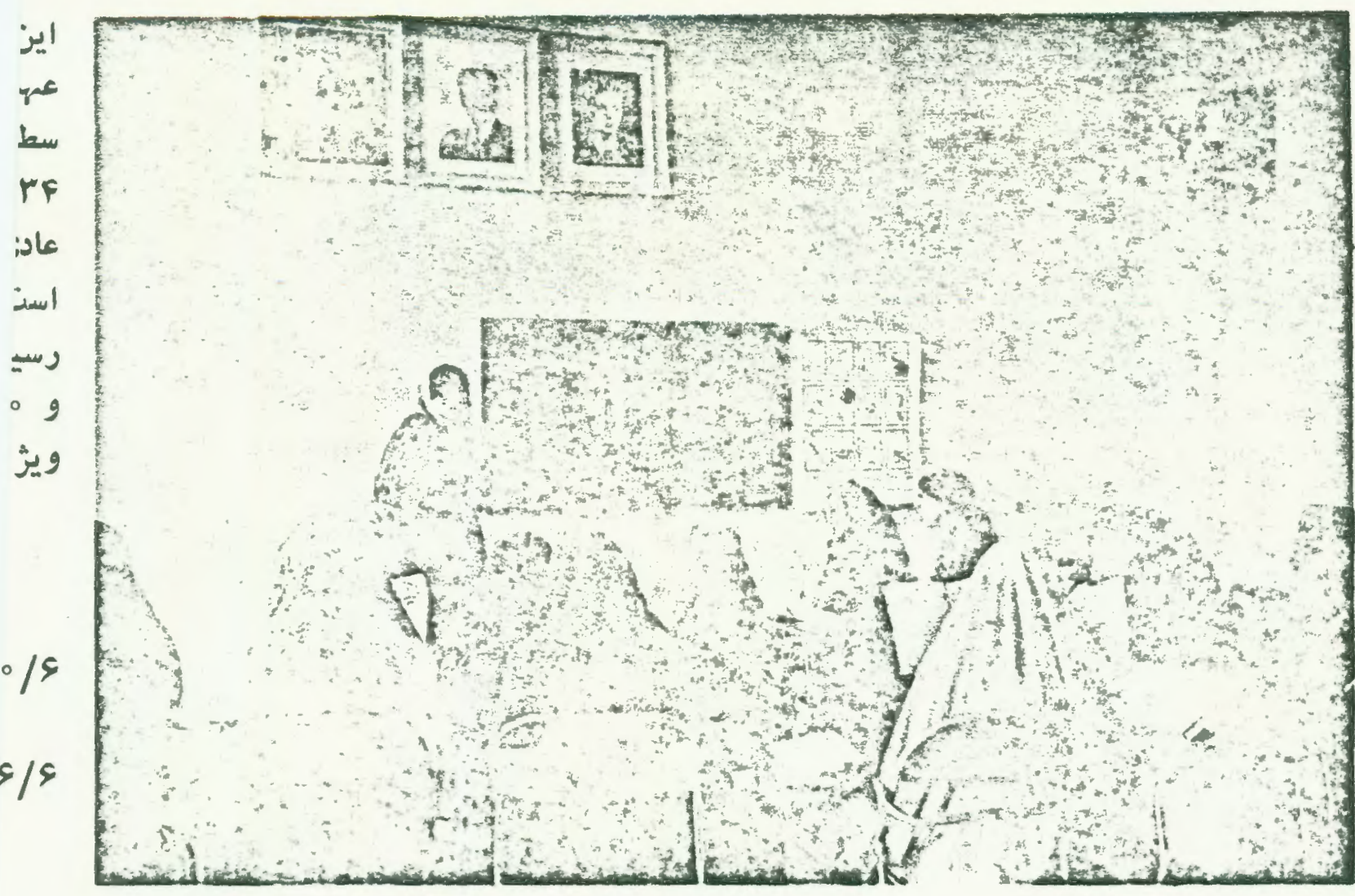

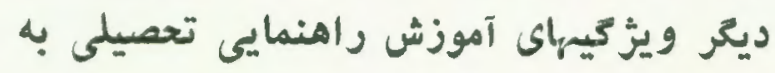
ـ كلاسى آموزشش، سازمان زنان، ثنهر كرد

$$
\text { شرح زير است: }
$$

تعداد آموز

ميانغين نسبت دانشآمسوز به كلاس نوس

Jhe

$$
\text { ن F\&/O }
$$

ميانغين نسبتداتشئشآموز بهآموز

$$
\text { نسبت لِّر ان دانشت آموز }
$$

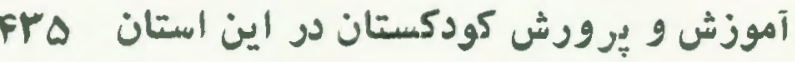

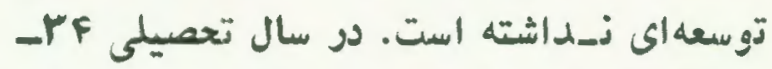

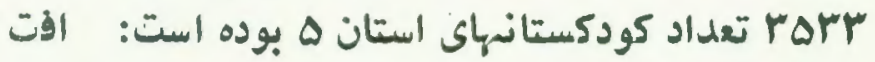

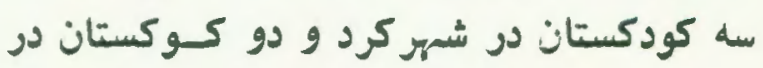

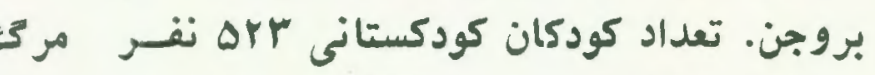

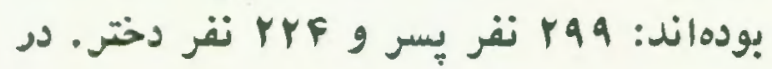

